FABIANA MARIA DE SOUZA LEORATTI

\title{
Resposta imune humoral na malária humana: quantidade e qualidade de anticorpos anti-Plasmodium falciparum
}

Dissertação apresentada ao Programa de Pós-Graduação em Fisiopatologia Experimental da Faculdade de Medicina da Universidade de São Paulo para obtenção do título de Mestre em Ciências

Área de concentração: Fisiopatologia Experimental

Orientador: Dra. Sandra do Lago Moraes

SÃO PAULO

2004 
"Nada acontece por acaso.

Não existe a sorte.

Há um significado por detrás de cada pequeno ato.

Talvez não possa ser visto

com clareza imediatamente, mas sê-lo-á antes que

se passe muito tempo."

\section{Richard Bach}




\section{À Deus,}

por nunca me desamparar nos momentos mais dificeis da vida.Conduzir-me com amor e sabedoria, deixando meu trilhar mais suave nesta longa jornada da vida. 
À MINHA MÃE querida Rosa Maria pela dedicação, força, amor e a esperança de uma vida melhor. Mostrando que vale a pena lutar pelos nossos ideais e acreditar que sempre exista uma solução para tudo em nossas vidas.

À MINHA DINDA Iolanda, ao SEU ESPOSO Marcos e também ao FILHO deles, Luís Eduardo, pela amizade incondicional e mostrando que as grandes batalhas na vida são enfrentadas com humildade e muito amor. 


\section{AGRADECIMENTOS}

À minha família pelo apoio e incentivo...

À minha orientadora Sandra do Lago Moraes pela oportunidade dada para a realização deste trabalho, carinho, afeto, apoio e ensinamentos. Conduzindo-me com amor nesta longa jornada científica, mostrando que é possivel construir e concretizar um sonho.

Ao Dr. Antônio Walter Ferreira pela amizade, pelos ensinamentos e um exemplo a seguir...

Ao Dr. Cristóvão Luis Pitangueira Mangueira, Flávia Cristina Kinskowski e a Milca Geane de Lamos Valim por participarem na realização deste trabalho.

Ao grupo da Profa. Dra. Maria das Graças Alecrim por terem cedido às amostras de malária complicada.

Aos membros da Banca de Qualificação Dra. Adelaide José Vaz, Dra. Irene Soares e Dr. Magnus Gidlund pelas sugestões dadas durante o Exame de Qualificação.

À minha querida amiga Sandra Trevisan Beck que iluminava o nosso laboratório com alegria.

À minha querida Kelly Aparecida Kanunfre, pela paciência e carinho comigo e minha mãe nos momentos de nossas vidas.

Aos meus queridos amigos Adriano Cappellazzo Coelho e Erika Hellena Esther Hoffmann da biologia molecular pelo companheirismo e pela amizade. 
À Dra. Maria Carmem Arroyo Sanchez, pelas criteriosas correções de português da minha tese, paciência e carinho esses anos de convivência.

Às meninas do Laboratório de Malária, Janaina Bezerra Miranda, Melissa Bastos, Amanda Farage Frade, Mônica Kudó, Patrícia Araújo, Elaine Antunes Lemos, Juliana Coelho, Kelly Dias Coura, pelos momentos agradáveis e descontraídos vividos nesses últimos anos, aprendendo a cada dia um pouquinho sobre a convivência humana. E agora temos uma nova companheira Guita Rubinsky Elefant que se tornou uma amiga. Também ao Flávio Augusto Alves que fez parte deste laboratório, mesmo apesar de uma breve passagem.

À Sônia Pedrozo Gomes, bibliotecária do Instituto de Medicina Tropical de São Paulo - IMT/SP pela disposição em sempre ajudar-me na procura de tantos artigos para a realização deste trabalho.

A todo pessoal do Laboratório de Soroepidemiologia e Imunologia do IMT/SP, Paulo, Ione, Artur, Renato, Eunice, Débora, Rogério, Mussya, Juliana, Selma, Edite, Sueli, Dr. Paulo César Cotrim, Mariko, Edna, Fábio, Fabrício, Maria Paulina, Célia, Márcia, Prianti, Ângelo, Beatriz, Dr. Hiro Goto.

A todos que de algum modo me incentivaram e contribuíram na realização deste trabalho. 
O presente trabalho foi realizado no Laboratório de Soroepidemiologia e Imunobiologia do Instituto de Medicina Tropical de São Paulo, com auxílio financeiro da Fundação de Amparo à Pesquisa do Estado de São Paulo (FAPESP) e do Laboratório de Investigação Médica (LIM-48) da Faculdade de Medicina. 


\section{SUMÁRIO}

ABREVIATURAS VII

UNIDADES DE MEDIDA IX IX

LISTA DE FIGURAS X X

LISTA DE TABELAS XIII

RESUMO XV

$\begin{array}{ll}\text { ABSTRACT XVII } & \text { X }\end{array}$

I. INTRODUÇÃO................................................................................... 19

1. Malária - A história...................................................................... 20

2. Malária - O agente etiológico....................................................... 21

3. Malária - Distribuição no mundo..................................................... 25

4. Malária - Características epidemiológicas....................................... 27

5. Malária - Doença ...................................................................... 29

6. Imunidade naturalmente adquirida............................................. 31

6.1. Imunidade especifica no estágio pré-eritrocítico........................ 32

6.2. Imunidade no estágio eritrocítico sexuado............................... 34

6.3. Imunidade no estágio eritrocítico assexuado.............................. 34

Resposta humoral no estágio eritrocítico assexuado.................... 36

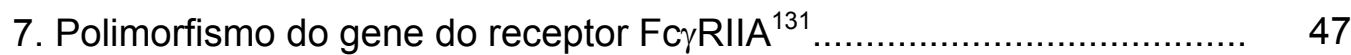

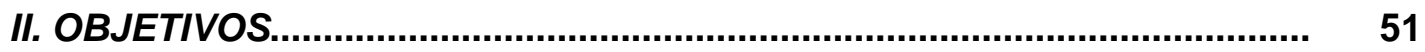

III. MATERIAL E MÉTODOS..........................................................

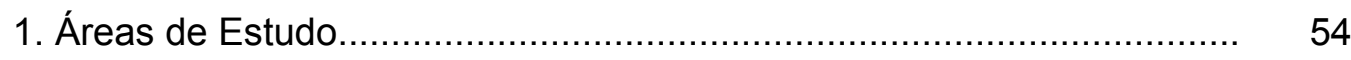

1.1. Peixoto de Azevedo, MT ...................................................... 54

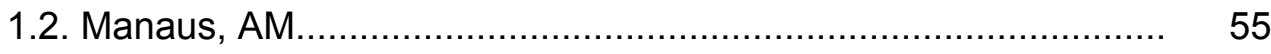


2. Casuística.

3.Aspectos éticos da pesquisa......................................................... 58

4. Antígenos de P. falciparum ............................................................. 58

4.1. Manutenção de $P$. falciparum ................................................. 58

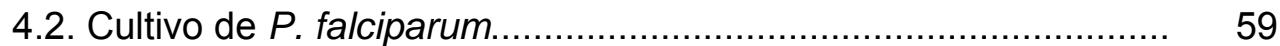

4.2.1.Preparo do extrato antigênico somático de $P$. falciparum...... 60

5. Obtenção de Anticorpos..................................................................... 61

6. Obtenção de Conjugados............................................................... 61

6.1. Conjugado enzimático proteína - peroxidase............................ 61

6.2. Conjugado proteína - biotina............................................. 62

7. Pesquisa de subclasses de lgG anti-formas eritrocitárias de 63 P.falciparum.

7.1.Padronização do ELISA

7.2. Estudo da Afinidade Funcional ou Avidez das Subclasses de IgG anti- P. falciparum.

8. Pesquisa de anticorpos $\lg E$ antiformas eritrocitárias de $P$. 65 falciparum.

8.1. Escolha do conjugado anti-lgE humana................................... 65

8.2. Padronização do ELISA - IgE............................................... 67

9. Pesquisa de Anticorpos IgM anti - P. falciparum ................................ 69

9.1. Otimização do ELISA - IgM Indireto.......................................... 69

10.Pesquisa de anticorpos IgA anti - P. falciparum .............................. 71

10.1.Otimização do ELISA -lgA................................................... 71 
11.Determinação de $\lg E$ e $\lg A$ Totais.

11.1.lgE total.

11.2. $\lg A$ total.

12. Determinação do polimorfismo do gene do receptor $F c \gamma R I I A^{131}$

12.1. Método de Extração de DNA com Fenol/ Clorofórmio

12.2. Oligonucleotídeos.

12.3. Amplificação por PCR

12.4. Eletroforese em Gel de Agarose

76

12.5. Digestão do produto de PCR com enzima de restrição

76

12.6. Eletroforese em Gel de Agarose

77

13. Análise Estatística dos Resultados

77

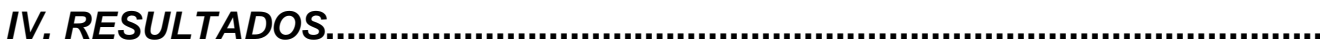

1.Padronização dos Testes Imunoenzimáticos para a Pesquisa de 80 Diferentes Classes e Subclasses de anticorpos anti- $P$. falciparum

1.1. Subclasses de IgG

1.2. Anticorpos lgE

1.3. Anticorpos IgM

1.4. Anticorpos IgA 
1.5. Outras patologias testadas nos ELISAs......

2. Quantidade e Qualidade dos Anticorpos

86

2.1. Anticorpos $\lg G$ e subclasses de $\lg G$

2.2. Anticorpos $\lg \mathrm{E}, \lg \mathrm{M}$, e $\lg \mathrm{A}$

2.3. Determinação do perfil de resposta humoral em diferentes formas clínicas da malária

3. Determinação do Polimorfismo do Receptor Fcy RIIA H/R ${ }^{131}$....

V. DISCUSSÃO

VI. CONCLUSÕES.

VII. ANEXOS.

141

VIII. REFERÊNCIAS BIBLIOGRÁFICAS. 


\section{ABREVIATURAS}

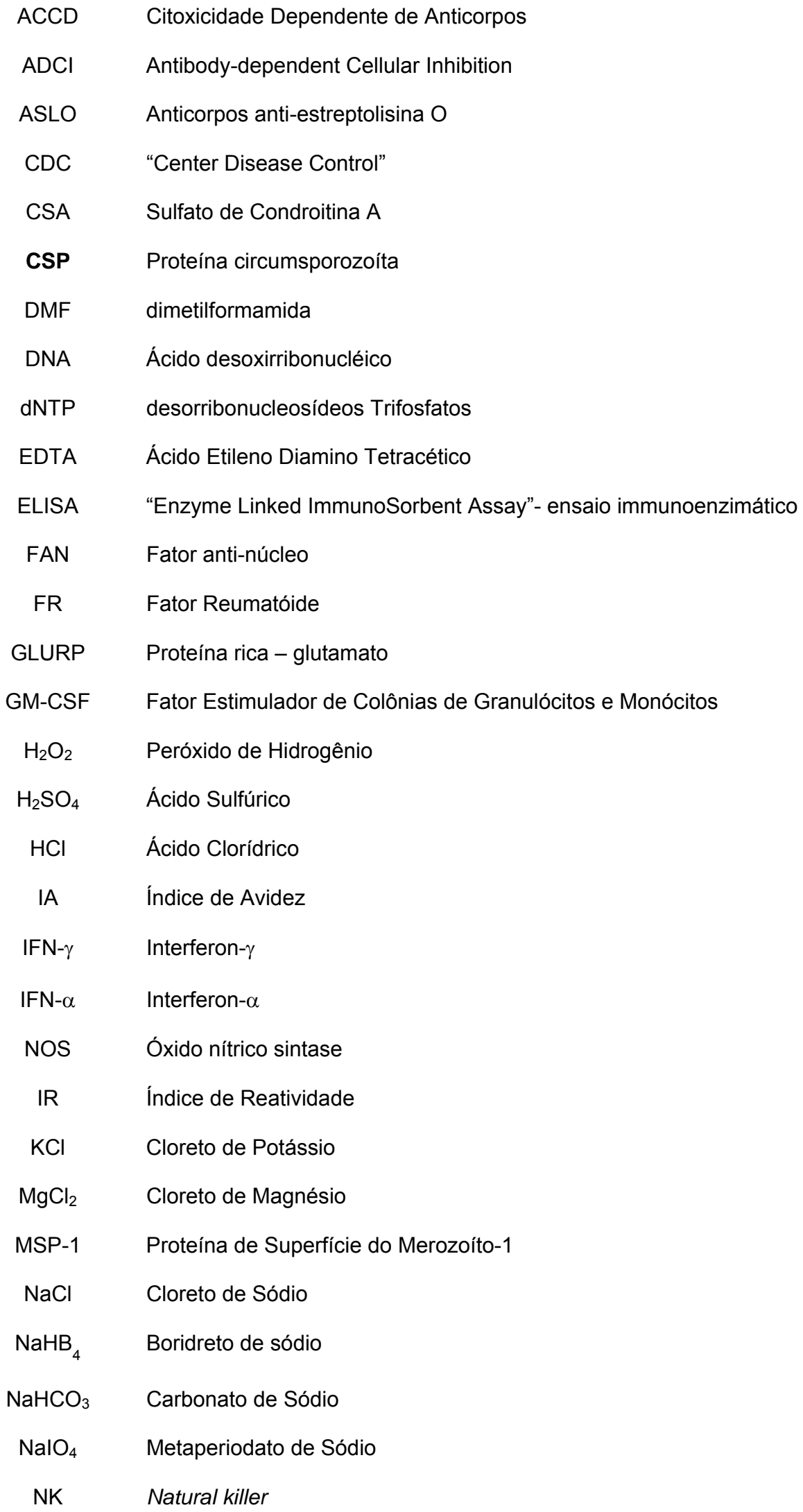




\begin{tabular}{|c|c|}
\hline NO & Oxido Nítrico \\
\hline OMS & Organização Mundial da Saúde \\
\hline PBS & "Phosphate Buffer Saline" - solução salina tamponada com fosfato \\
\hline PBS-Tw20 & PBS contendo Tween 20 0,05\% \\
\hline$P C R$ & Reação em Cadeia da Polimerase \\
\hline PCR & Proteína C Reativa \\
\hline Pf & Plasmodium falciparum \\
\hline PfEMP1 & Plasmodium falciparum erytrocyte membrane protein 1 \\
\hline PIACM & Plano de Intensificação das Ações de Controle da Malária \\
\hline PM & Matriz peritrófica \\
\hline $\mathrm{Pm}$ & Plasmodium malariae \\
\hline PMSF & Fluoreto de metilsufonila \\
\hline Pv & Plasmodium vivax \\
\hline $\mathrm{QBC}^{\circledR}$ & Quantitative Butty Coat \\
\hline qsp & quantidade suficiente para \\
\hline RESA & Antígeno da Superfície do Eritrócito Infectado por Trofozoítos jovens \\
\hline SDS & Dodecil sulfato de sódio \\
\hline SLR & Soro Limiar de Reatividade \\
\hline TAE & Tampão Tris-acetato-EDTA \\
\hline TGF- $\beta$ & Fator de Crescimento Transformador- $\beta$ \\
\hline TMB & Tetrametilbenzidina \\
\hline TNF- $\alpha$ & Fator de Necrose Tumoral- $\alpha$ \\
\hline TRAP & Trombospondina \\
\hline Tris & Tris (hidroximetil)aminometano \\
\hline TSP & Trombospondina \\
\hline UAR & Unidade de Alto Risco \\
\hline UV & Luz ultravioleta \\
\hline
\end{tabular}


UNIDADES DE MEDIDA

$\begin{array}{cl}\mathrm{bp} & \text { par de base } \\ g & \text { aceleração da gravidade }\left(\cong 9,8 \mathrm{~m} / \mathrm{s}^{2}\right) \\ \mathrm{M} & \text { molar } \\ \mathrm{mg} & \text { miligrama } \\ \mathrm{mL} & \text { mililitro } \\ \mathrm{mM} & \text { milimolar } \\ \mu \mathrm{g} & \text { micrograma } \\ \mu \mathrm{L} & \text { microlitro } \\ \mathrm{N} & \text { normal } \\ \mathrm{ng} & \text { nanograma } \\ \mathrm{U} & \text { Unidade }\end{array}$




\section{LISTA DE FIGURAS}

Figura 1 Ciclo de vida do Plasmodium 23

Figura 2 Possíveis mecanismos de clareamento de 42 eritrócitos infectados por $P$. falciparum mediados por anticorpos citofílicos

Figura 3 Estruturas e características dos diferentes receptores para a região $F c$ de $\lg G(F c \gamma R)$

Figura 4 Freqüências dos anticorpos $\lg$ e das subclasses lgG1, IgG2, lgG3 e IgG4 anti-formas eritrocitárias de $P$. falciparum de baixa avidez e de alta avidez no total de indivíduos $(n=270)$ de área endêmica de malária e agrupados entre os indivíduos infectados por plasmódios (INF) $(n=233)$ e os não infectados (NÃO INF) $(n=37)$ testados no ELISA.

Figura 5 Freqüências de amostras de soro positivas para anticorpos IgG e subclasses IgG1, IgG2, IgG3 e IgG4 anti-formas eritrocitárias de $P$. falciparum no ELISA no total de 270 indivíduos e considerando a presença ou não de infecção por Plasmodium distribuídas entre os grupos de indivíduos com mais de 5 malárias anteriores $(>5)(n=138)$, de uma a cinco malárias anteriores (1 a 5) $(n=86)$ e de primoinfectados (primo) $(n=30)$.

Figura 6 Comparação dos níveis dos anticorpos lgG (em índice de reatividade (IR)) e das subclasses IgG1, lgG2, IgG3 e IgG4 anti-formas eritrocitárias de $P$. falciparum (em concentração, $\mu \mathrm{g} / \mathrm{mL}$ ) entre os grupos de indivíduos com mais de 5 malárias anteriores $(>5) \quad(n=138)$, de uma a cinco malárias anteriores (1 a 5) $(n=86)$ e de primo-infectados (primo) $(n=30)$ obtidos no ELISA.

Figura 7 Comparação dos níveis de avidez (IA) dos anticorpos IgG e das subclasses IgG1, IgG2, IgG3 e IgG4 anti-formas eritrocitárias de $P$. falciparum entre os grupos de indivíduos com mais de 5 malárias anteriores $(>5) \quad(n=138)$, de uma a cinco malárias anteriores (1 a 5) $(n=86)$ e de primo-infectados (primo) $(n=30)$ obtidos no ELISA. 
Figura 8 Freqüências de amostras de soros positivas anticorpos $\lg \mathrm{M}$, IgA e IgE anti-formas eritrocitárias de $P$. falciparum no ELISA no total de 270 indivíduos e considerando a presença ou não de infecção por Plasmodium distribuídas entre os grupos de indivíduos com mais de 5 malárias anteriores $(>5)(n=138)$, de uma a cinco malárias anteriores (1 a 5) $(n=86)$ e de primo-infectados (primo) $(n=30)$.

Figura 9 Comparação dos níveis dos anticorpos IgM (IR) e 105 $\lg A(I R)$ e de $\lg E(\mu \mathrm{g} / \mathrm{mL})$ anti-formas eritrocitárias de $P$. falciparum entre os grupos de indivíduos com mais de 5 malárias anteriores $(>5)(n=138)$, de uma a cinco malárias anteriores (1 a 5) $(n=86)$ e de primo-infectados (primo) $(n=30)$ obtidos no ELISA.

Figura 10 Freqüências dos anticorpos $\lg G$, IgG1, IgG2, IgG3, IgG4, IgM, IgA e IgE anti-formas eritrocitárias de $P$. falciparum no ELISA com 233 amostras de soro de indivíduos com malária, 70 com complicações clínicas por malária (MC), 148 sem complicações clínicas (MNC) e 15 assintomáticos (AS).

Figura 11 Freqüências das subclasses IgG1, IgG2, IgG3 e IgG4 e de IgG anti-formas eritrocitárias de $P$. falciparum de baixa avidez e de alta avidez divididas entre os indivíduos com malária complicada (MC) $(n=70)$, indivíduos sem complicações clínicas por malária (MNC) $(n=148)$ e indivíduos infectados assintomáticos (AS) $(n=15)$ testados no ELISA.

Figura 12 Distribuição dos níveis dos anticorpos IgG (IR) e subclasses $\lg G 1$, IgG2, IgG3 e $\operatorname{lgG} 4(\mu \mathrm{g} / \mathrm{mL})$ antiformas eritrocitárias de $P$. falciparum no ELISA, entre os indivíduos com malária complicada (MC) $(n=70)$, indivíduos sem complicações clínicas por malária (MNC) $(n=148)$ e indivíduos com malária assintomáticos (AS) $(n=15)$.

Figura 13 Distribuição dos níveis dos anticorpos $\lg M(\mathrm{IR}), \lg A$

(IR) e $\lg E(\mu \mathrm{g} / \mathrm{mL})$ anti-formas eritrocitárias de $P$. falciparum no ELISA, entre os indivíduos com malária complicada (MC) $(n=70)$, indivíduos sem complicações clínicas por malária (MNC) $(n=138)$ e indivíduos com malária assintomática $(\mathrm{AS})(\mathrm{n}=15)$. 
Figura 14 Resultados individuais da pesquisa de anticorpos $\lg G$, IgG1, IgG2, IgG3, IgG4, IgM, IgA e $\lg E$ divididos pela forma clínica de malária: malária complicada $(n=70)$, malária não complicada $(n=148)$ e malária assintomática $(n=15)$.

Figura 15 Resultados da digestão do produto de PCR digerido com a enzima de restrição Bsh1236I (FnuDII) de algumas amostras com a presença ou ausência do polimorfismo no receptor Fc $\gamma$ RIIA $H / R^{131}$. 


\section{LISTA DE TABELAS}

Tabela 1 Resultados da padronização do ELISA para pesquisa de anticorpos $\lg G 1, \lg G 2$, IgG3 e $\lg G 4$ anti- $P$. falciparum em 12 amostras de soros positivos e 12 negativos para anticorpos lgG anti- $P$. falciparum.

Tabela 2 Resultados do ELISA para pesquisa de anticorpos IgE específicos com conjugados anti-IgG humana peroxidase ( $\alpha$-lgG-Po), anti-lgE humana marcado com peroxidase $(\alpha-\lg E-P o)$, anti-lgE humana marcada com biotina $(\alpha-\lg E-B)$.

Tabela 3 Freqüências de amostras de soro de indivíduos com outras patologias positivas nos ELISA para pesquisa de diferentes classes e subclasses de anticorpos anti-formas eritrocitárias de $P$. falciparum.

Tabela 4 Resultados das medianas dos níveis e da avidez dos anticorpos IgG, IgG1, IgG2, IgG3 e IgG4 antiformas eritrocitárias de $P$. falciparum obtidos no ELISA com 270 amostras de soro de indivíduos de área endêmica de malária.

Tabela 5 Resultados das freqüências de amostras de soros positivas no ELISA para anticorpos lgG e subclasses IgG1, IgG2, IgG3 e IgG4 anti-formas eritrocitárias de $P$. falciparum no total de 270 indivíduos residentes em áreas endêmicas de malária e agrupadas pelos resultados da pesquisa de plasmódios pela gota espessa e $\mathrm{QBC}^{\circledR}$.

Tabela 6 Resultados dos coeficientes de correlação de Spearman e das probabilidades que foram significantes a $95 \%$ quando correlacionados variáveis preditoras de exposição à malária (idade, número de episódios anteriores de malária) e os níveis de anticorpos lgG e subclasses $\lg G 1$, IgG2, lgG3 e IgG4 anti-formas eritrocitárias e os respectivos níveis de avidez no ELISA. 
Tabela 7 Resultados das freqüências (\%) de positivos e dos

100 índices de reatividade (IR) (em mediana) de anticorpos $\lg \mathrm{M}$, IgA e IgE anti-formas eritrocitárias de $P$. falciparum obtidos no ELISA com amostras de soros de indivíduos residentes em áreas endêmicas de malária divididos pelos resultados da pesquisa de plasmódios pela gota espessa e QBC ${ }^{\circledR}$.

Tabela 8 Resultados das medianas dos níveis de anticorpos IgE anti-formas eritrocitárias de $P$. falciparum no ELISA com 238 amostras de soro de indivíduos de área endêmica de malária.

Tabela 9 Interações entre os níveis de diferentes classes e subclasses de anticorpos anti-formas eritrocitárias de $P$. falciparum entre os grupos de indivíduos com malária complicada, com malária não complicada e com malária assintomática.

Tabela 10 Resultados do ELISA para pesquisa de anticorpos IgG2 anti-formas eritrocitárias de $P$. falciparum divididos nos grupos de indivíduos positivos para Plasmodium por Nested-PCR sintomáticos e assintomáticos e com $(H / H$ ou $H / R)$ e sem $(R / R) o$ polimorfismo no receptor Fc $\gamma$ RIIA $H^{131}$, determinado por PCR após digestão com enzima de restrição alelo específica. 


\section{RESUMO}

LEORATTI, F. M. S. Resposta imune humoral na malária humana: quantidade e qualidade de anticorpos anti - Plasmodium falciparum. São Paulo, 2004. p.165 Dissertação (Mestrado) - Faculdade de Medicina, Universidade de São Paulo.

A aquisição de imunidade na malária é lenta e para ser mantida requer a exposição a variantes antigênicas múltiplas dos plasmódios e a maturação do sistema imune com a idade. Muitos dos estudos da resposta imune humoral na malária se concentraram na avaliação da especificidade antigênica da resposta, mas evidências de que a imunidade protetora estaria associada à mudança de classes e subclasses dos anticorpos mostraram à importância de se considerar a qualidade dos anticorpos produzidos, que envolve a afinidade da porção $F_{a b}$ pelo antígeno e a natureza da região $F_{c}$ que determina a função do anticorpo.

Neste estudo determinamos o padrão de resposta imune humoral específica de indivíduos naturalmente expostos à malária residentes em área endêmica no Brasil. As classes IgG, IgM, IgE, IgA e subclasses IgG1, IgG2, IgG3 e IgG4 de anticorpos anti-Plasmodium falciparum foram determinadas por teste ELISA usando como antígeno formas eritrocitárias de P.falciparum. Os resultados foram analisados em função (a). da presença ou não de infecção por plasmódios; (b). de variáveis preditoras de exposição à malária como idade, número de episódios anteriores de malária e tempo de permanência na área endêmica; (c) de diferentes formas clínicas da malária , malária complicada (MC), não complicada (MNC) e assintomática (AS).

Maiores níveis de anticorpos lgG, lgG1, lgG2 e lgG3 foram observados nos indivíduos não infectados do que nos indivíduos infectados e o oposto foi observado para IgG4. Os resultados dos anticorpos também foram avaliados em relação ao número de episódios anteriores de malária, e os níveis de $\operatorname{lgG} 1$, IgG2 e IgG3 foram maiores nos indivíduos que relataram mais de 5 
malárias, enquanto os níveis de $\lg \mathrm{M}, \lg \mathrm{A}$ e $\lg \mathrm{E}$ foram maiores nos indivíduos primo-infectados.

Entre os indivíduos com melhor resposta à infecção, ou seja, sem complicações de malária ou assintomáticos, foi observado o predomínio dos anticorpos lgG, lgG1, lgG2 de alta avidez e lgG3 de baixa avidez. Já os indivíduos com complicações clínicas por malária apresentaram o predomínio de anticorpos lgG4, lgE e lgM.

Também determinamos em parte da população o polimorfismo H131 do gene do receptor $F c \gamma$ RIIA que permite a ligação à $F_{c}$ de IgG2 humana, conferindo assim a capacidade citofílica a essa subclasse. A alta freqüência $(67,9 \%)$ encontrada e os maiores níveis de IgG2 nos indivíduos infectados assintomáticos que carregavam o polimorfismo, sugere o papel protetor de IgG2 nesta população.

Nossos resultados mostram que mesmo em populações de regiões com transmissão instável de malária pode ser observado o desenvolvimento de um certo grau de imunidade protetora quando anticorpos apropriados são produzidos. 


\begin{abstract}
LEORATTI, F. M. S. Humoral immune response in human: quantity and quality anti-Plasmodium falciparum antibodies. São Paulo, 2004. Dissertação (Mestrado) - Faculdade de Medicina, Universidade de São Paulo
\end{abstract}

The development of protective immunity against malaria is slow and to be maintained requires to the exposure to multiple antigenic variants malaria parasites and age-associated maturation of the immune system. Many studies $\mathrm{n}$ the humoral immune response have focused on the antigenic specificity of the response. But evidences that the protective immunity is associated to different classes and subclasses antibodies show the importance to consider the quality of the response, which involves both the affinity of the $F_{a b}$ receptor for the antigen and the nature $F_{c}$ region, which determines antibody function.

In this study, we have evaluated the humoral immune response of naturally exposed individuals to malaria living in endemic areas of Brazil. We determined $\lg G$, IgG1, $\lg G 2$, IgG3, $\lg G 4 \lg M$, $\lg E$, IgA antibodies against Plasmodium falciparum blood stages by ELISA. The results were analyzed in function of: (a) presence or not of Plasmodium infection ; (b) factors related to prior malaria exposure such as age, number of previous clinical malaria attacks and the time living in malaria endemic areas; (c) different forms of malaria such as, complicated, uncomplicated and asymptomatic.

The highest levels of $\lg G$, IgG1, IgG2 and IgG3 antibodies were observed in infected individuals than uninfected individuals and the opposite was observed to IgG4 antibodies. Individuals reporting more than five previous clinical malaria attacks have showed predominance of $\lg \mathrm{g} 1, \lg G 2$ and $\lg \mathrm{g} 3$ antibodies, while individuals reporting five or less previous clinical malaria showed predominance of $\lg \mathrm{M}, \lg \mathrm{A}$ and $\lg \mathrm{E}$ antibodies.

Among individuals with uncomplicated and asymptomatic malaria was observed predominance of high-avidity lgG, IgG1, IgG2 antibodies and low- 
avidity IgG3 antibodies in levels and frequencies, while $\lg G 4$, IgE and $\lg M$ antibodies were predominant in individuals with complicated malaria.

Since our results have pointed to a protective role of IgG2 antibodies and IgG2 can act as cytophilic antibodies in individuals carrying the H131 polymorphism of the FcyIIA receptor, we also investigated the occurrence of this polymorphism in part of the population. We found the H131 polymorphism in $67,9 \%$ of the individuals, and the highest IgG2 levels were observed among asymptomatic individuals carrying this allele, suggesting the protective role of $\lg \mathrm{g} 2$ in this population.

Taken together the results showed that even in unstable transmission of malaria it with can be observed of protective immunity against malaria when antibodies appropriated are produced. 
I. INTRODUÇÃO 


\section{MALÁRIA - A História}

A malária originou-se provavelmente na África há milhões de anos e se espalhou para regiões tropicais, subtropicais e temperadas do Velho Mundo através das migrações e então para o Novo Mundo com os exploradores, missionários e escravos. Há 4700 anos atrás, um cânone da medicina chinesa Nei Ching referiu-se a ocorrências epidêmicas de episódios febris e o aumento do baço, que provavelmente se tratava de malária. Episódios febris são relatados também em manuscritos de outras civilizações como grega, romana, assíria, indiana, arábica (BRUCE-CHWATT, 1985; CARTER \& MENDIS, 2002; COX, 2002).

Estas febres intermitentes receberam o nome de malária, em decorrência da associação entre a doença e os miasmas provenientes de áreas alagadas que tinham "maus ares", no italiano "mal'aria", pois se acreditava que a doença era transmitida através do ar (BRUCE-CHWATT, 1985).

O primeiro evento importante na história da malária foi a descoberta da "Cinchona" para o tratamento das febres, no século XVII. Seu uso se espalhou rapidamente por toda Europa e era conhecida pelo nome de "pó dos jesuítas". Apenas em 1820 Pelletier e Caventou isolaram os alcalóides, quinino e cinchonina (BRUCE-CHWATT, 1985; KNELL, 1991).

O parasita da malária foi visto pela primeira vez em 1880, por um cirurgião militar francês, Alphonse Laveran, que estava procurando por uma causa bacteriana da malária em necropsias de pacientes e imediatamente percebeu 
que os parasitas eram os responsáveis pela doença (KNELL, 1991; COX, 2002).

Em 1897, Ronald Ross em Secunderabad na Índia, provou que mosquitos Culex transmitiam a malária aviária e demonstrou o ciclo de vida completo do parasita utilizando como modelo, a malária aviária. Esta descoberta levou Ross à conclusão de que a malária humana poderia ser transmitida da mesma maneira (KNELL, 1991; DOBSON, 1999).

No mesmo ano, os malariologistas italianos Giovanni Battista, Amico Bignami e Giuseppe Bastianelli conduziram seus experimentos na transmissão da malária humana, mostrando o ciclo de vida completo do parasita e que os mosquitos anofelinos eram os responsáveis pela transmissão da doença (DOBSON, 1999).

\section{MALÁRIA - O AGENTE ETIOLÓGICO}

A malária é uma doença infecciosa causada pelo protozoário do gênero Plasmodium, da família Plasmodiidae, filo Apicomplexa, que infecta alternadamente um hospedeiro vertebrado e um hospedeiro invertebrado. $\mathrm{O}$ gênero Plasmodium foi definido baseando-se no ciclo de vida do parasita (Figura 1), com uma fase de reprodução sexuada seguida por três fases de reprodução assexuada. A fase sexuada (fertilização) ocorre no lúmen do estômago do mosquito e a primeira fase assexuada (esporogonia), no epitélio do estômago e corpo do mosquito Anopheles; as outras duas fases ocorrem em um hospedeiro vertebrado, a segunda fase ocorre no fígado 
(esquizogonia exoeritrocítica) e a terceira fase ocorre na circulação sangüínea (esquizogonia eritrocítica) (KNELL, 1991).

Os esporozoítos são transmitidos ao hospedeiro vertebrado pela picada da fêmea do gênero Anopheles e caem rapidamente na circulação sangüínea até chegarem aos hepatócitos. Recentes descobertas demonstraram que os esporozoítos passam por vários hepatócitos antes da invasão e o subseqüente desenvolvimento hepático (MOTA et al, 2001). O processo de invasão envolve proteínas de superfície do esporozoíto, como domínios de trombospondina na proteína circumsporozoíta (CSP) e a proteína relacionada à adesão à trombospondina (TRAP) e moléculas de superfície do hospedeiro vertebrado (FUJIOKA et al, 2002; WEATHERALL et al, 2002). Estes domínios ligam-se especificamente a sulfato de proteoglicanos nos hepatócitos no endotélio sinusoidal e nas células de Kuppfer (MILLER et al, 2002). Após a invasão, os esporozoítos se transformam em trofozoítos hepáticos que amadurecem e formam milhares de merozoítos, os quais são liberados na circulação sangüínea e invadem os eritrócitos, iniciando a fase eritrocítica. No caso de $P$. vivax e $P$. ovale, alguns esporozoítos não se desenvolvem e podem formar um estágio dormente, chamado hipnozoíto, que pode permanecer no fígado por semanas a anos, e quando reativado provoca recidivas da doença.

No ciclo eritrocítico, os merozoítos passam por um processo de amadurecimento para formação de trofozoítos, que realizam várias divisões para formação de esquizontes. Os esquizontes rompem os eritrócitos e assim recomeça uma nova invasão nos eritrócitos. Concomitantemente, uma 
pequena proporção de merozoítos diferencia-se em gametócitos macho e fêmea. Estes, ao serem ingeridos pelo mosquito se transformam em gametas e ocorre a fertilização no lúmen do estômago do mosquito com a formação dos oocinetos. Os oocinetos atravessam duas barreiras, a matriz peritrófica (PM) e o epitélio do estômago, para a formação dos oocistos, que passam por um processo complexo de desenvolvimento para a produção de milhares de esporozoítos e chegam à glândula salivar do mosquito (BRUCECHWATT, 1985; FUJIOKA et al, 2002). Quando o mosquito fêmea do gênero Anopheles, carregando esporozoítos nas glândulas salivares, se alimentar novamente, irá infectar outro hospedeiro e desta maneira iniciará um novo ciclo.

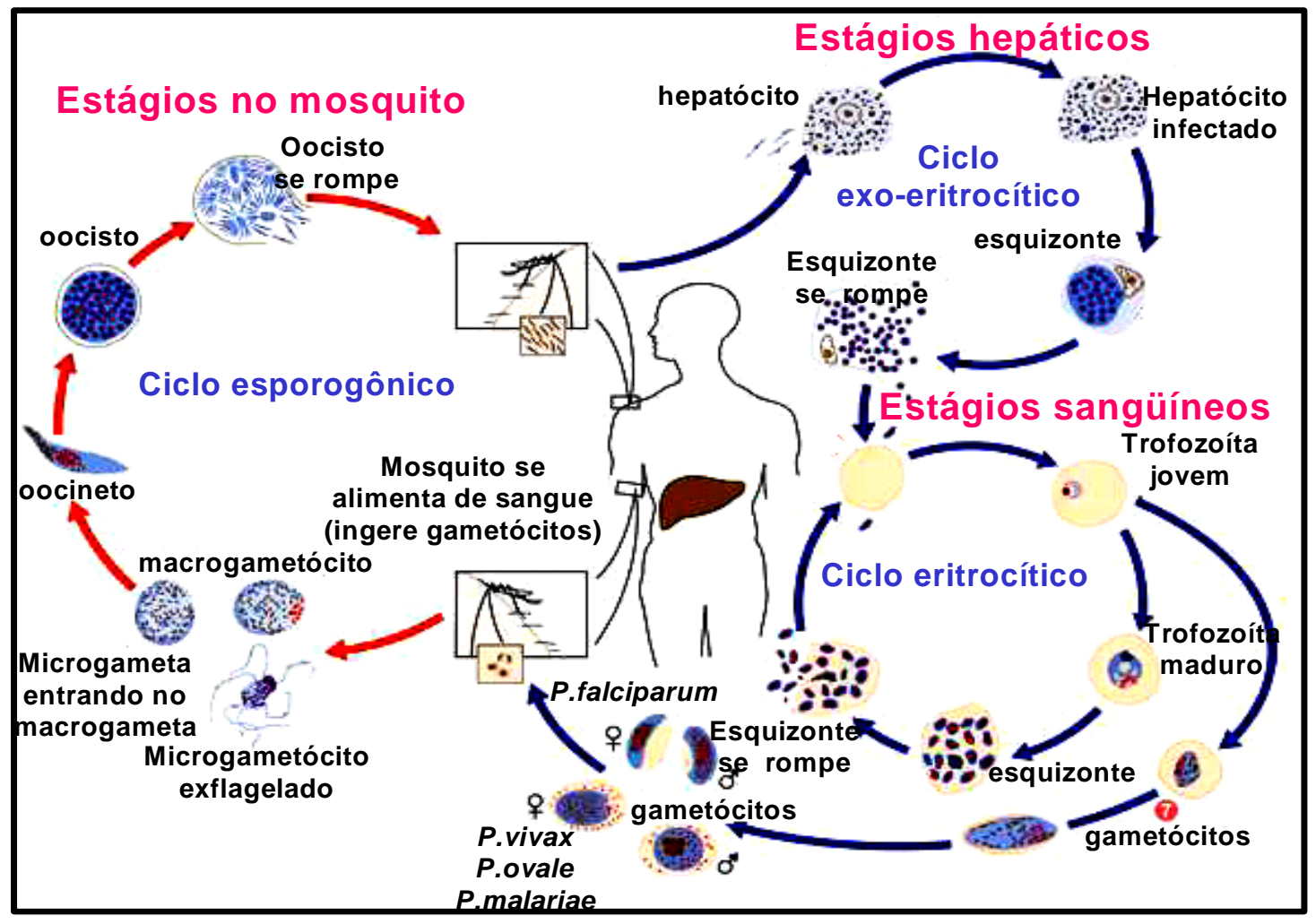

Figura. 1. Ciclo de vida das espécies de Plasmodium infectantes ao homem (adaptado de http://www.dpd.cdc.gov) 
Existem aproximadamente 156 espécies de plasmódios, mas somente quatro espécies são infectantes ao homem: $P$. vivax, descrito por Grassi e Feletti em 1890, P. falciparum descrito por Welch em 1897, P. malariae descrito por Laveran em 1881 e P. ovale descrito por Stephens em 1922. Vários nomes foram dados à doença causada por esses parasitas de acordo, com o tipo de febre intermitente que ocasionavam, como terçã benigna, terçã simples ou somente terçã para $P$. vivax; terçã para $P$.ovale; quartã para $P$. malariae e maligna terçã, subterçã, perniciosa, tropical para P. falciparum. Atualmente esses nomes não são mais utilizados (BRUCECHWATT, 1985).

Plasmodium vivax é uma espécie amplamente distribuída no mundo ocorrendo em regiões tropicais e subtropicais e raramente em regiões temperadas. P. falciparum predomina na África e sudeste da Ásia. Estas duas espécies coexistem em muitas partes do mundo, mas $P$. vivax é raro no oeste da África. P. malariae tem uma prevalência menor que no passado, com distribuição limitada à África e mais raramente no Oeste Pacífico e na América do Sul. $P$. ovale é o que tem a mais limitada distribuição, restringindo-se à África sub-saariana e à Ásia e sendo sabidamente endêmico somente na Papua Nova Guiné e Filipinas (CARTER \& MENDIS, 2002). 


\section{MALÁRIA - DISTRIBUIÇÃO NO MUNDO}

A malária ainda é a maior endemia do mundo e um grande obstáculo ao desenvolvimento econômico de comunidades e nações. Segundo dados da Organização Mundial de Saúde de 1998, 40\% da população mundial habitam áreas de risco da doença, que causa de 300 a 500 milhões de casos clínicos por ano, com mais de um milhão de mortes, principalmente de crianças com menos de cinco anos de idade. Embora a África detenha $90 \%$ dos casos, a globalização da doença é um fato atual que preocupa autoridades dos países desenvolvidos.

A malária é também uma doença re-emergente em áreas onde estava sob controle ou erradicada, como em repúblicas da Ásia Central e na Coréia (WHO, 2003). Nos últimos anos, o número de casos de malária tem aumentado em países onde a doença não é endêmica, devido à mobilidade de populações, como viajantes, migrantes, tropas e refugiados, caracterizando a chamada malária importada. Um estudo realizado nos países da União Européia, no período de 1999 a 2000, mostrou a incidência de 1.659 casos de malária falciparum importada. Destes, 27 apresentavam infecção mista (P. falciparum e $P$. vivax em 11casos, $P$. falciparum e $P$. ovale em 10 casos e P. falciparum e P. malariae em 6 casos). Cinco indivíduos morreram após retornarem de países africanos (JELINEK et al, 2002). Nos Estados Unidos ocorrem em média 1.300 casos de malária importada ao ano (www.ahcpub.com).

Casos de malária transfusional também têm sido relatados em diferentes partes do mundo. Nos Estados Unidos, a incidência de casos notificados de 
malária transfusional, no período de 1963 a 1999, foi de 93 indivíduos, dos quais 10 morreram (6 por $P$. falciparum, 2 por $P$. vivax e 2 por $P$. malariae) (MUNGAl et al, 2001). Em países onde existem áreas com diferentes situações epidemiológicas de malária (sem transmissão, baixa transmissão e alta transmissão), como o Brasil, o risco de malária transfusional é considerável devido ao fluxo de populações, porém a sua real incidência é desconhecida (SAÉZ-ALQUÉZAR et al, 1998).

As campanhas de erradicação realizadas no Brasil a partir da década de 40 fizeram cair de seis milhões de casos estimados anualmente, na década de 1940, para 52.469 casos em 1970. O aumento gradual que aconteceu, para a Região Amazônica, a partir de então foi decorrente das migrações de populações atraídas inicialmente pelos projetos de colonização, construção de rodovias e hidrelétricas, mineração e agricultura (DEANE, 1988).

Em 2000, os últimos dados oficiais relataram 615.245 casos de malária no Brasil, sendo que mais de $99 \%$ dos casos ocorreram na Região Amazônica. Em 2001, registraram-se 388.807 casos de malária, representando uma redução de cerca de $40 \%$. Esta redução de casos de malária foi decorrente da implantação do Plano de Intensificação das Ações de Controle da Malária (PIACM) pelo Ministério da Saúde, desencadeando uma série de ações na região Amazônica (FUNASA, 2003).

Os números alarmantes de casos de malária e a complexidade dos fatores relacionados ao controle levaram a OMS a realizar em outubro de 1992, em Amsterdã-Holanda, uma Conferência Ministerial em Malária. Nessa conferência foi elaborada uma declaração mundial em relação ao 
controle da doença, apontando quatro elementos básicos que deveriam ser aplicados a qualquer local independente das condições existentes:

- Diagnóstico precoce e tratamento rápido;

- Planificação e implementação de medidas preventivas e seletivas, incluindo o controle do vetor;

- Detecção, controle e prevenção de epidemias;

- Reforço da capacidade local em pesquisa básica e aplicada aliada a uma avaliação regular da situação da malária em nível nacional (WHO, 1992).

Em outubro de 1998, a OMS lançou uma campanha global intitulada "Roll back malaria" (RBM), traduzida para o português como "Retroceder a Malária", que tem como objetivo buscar um maior comprometimento não apenas do setor de saúde, mas também dos setores governamentais e privados onde as atividades pudessem, direta ou indiretamente, afetar a situação da malária, de organizações não-governamentais e das próprias comunidades afetadas. Com as ferramentas disponíveis e o desenvolvimento de novas pretende-se diminuir a mortalidade causada pela malária em 50\% até o ano 2010 (WHO, 1999).

\section{MALÁRIA - CARACTERÍSTICAS EPIDEMIOLÓGICAS}

A Organização Mundial da Saúde definiu quatro diferentes situações epidemiológicas, para avaliar a prevalência de malária em uma definida população (KNELL, 1991): 
- Hipoendêmica: índice esplênico que menor 10\%. Transmissão da malária é baixa e poucos efeitos na população.

- Mesoendêmica: índice esplênico entre 11 e 50\%. É típica em vilas rurais e zonas subtropicais.

- Hiperendêmica: índice esplênico maior que $50 \%$ em crianças e acima de $25 \%$ em adultos. Transmissão é intensa, mas sazonal.

- Holoendêmica: índice esplênico em crianças é maior que $75 \%$, mas baixo em adultos. A transmissão é intensa e contínua.

Atualmente, tem sido mais usada a classificação de endemicidade da malária no mundo em três categorias (segundo MACDONALD, 1957): malária endêmica estável, malária endêmica instável e malária epidêmica. As diferenças na estabilidade da transmissão da malária são conseqüências das características biológicas das espécies e comportamentais dos vetores Anopheles e também do meio ambiente nas diferentes regiões (CARTER \& MENDIS, 2002).

Malária endêmica estável ocorre em regiões onde a população está continuamente exposta a uma taxa constante de inoculação de parasitas por mosquitos infectados; é comum na África sub-saariana. O principal vetor da doença é A. gambiae. A transmissão estável é mantida pelo contato homemmosquito e devem-se considerar também as condições climáticas, calor e umidade com poucas flutuações que favorecem a longevidade e o rápido desenvolvimento dos parasitas no interior dos mosquitos.

Na malária endêmica instável, a população está sujeita a grandes flutuações nas taxas de inoculação dos parasitas. A transmissão é focal, 
sazonal e relacionada à atividade ocupacional. Ocorre diversidade de espécies envolvidas, sendo $P$. falciparum e $P$. vivax as mais comuns.

A malária epidêmica é uma forma extrema de malária instável. Ocorre quando uma população não imune está sujeita à transmissão da malária acima da que ocorre normalmente. Epidemias causadas por $P$. falciparum podem ter altos índices de mortalidade (CARTER \& MENDIS, 2002).

\section{MALÁRIA - DOENÇA}

O período de incubação da doença varia de acordo com a espécie infectante, a média é de 12 dias para $P$. falciparum, 14 dias para $P$. vivax e 30 dias para P. malariae. Com algumas cepas de P. vivax, zonas temperadas ou subtropicais pode haver um período de incubação prolongado, 8 a 10 meses. Nos casos em que a causa de infecção é uma transfusão de sangue, o período de incubação geralmente é breve, mas varia de acordo com o número de parasitas contidos no sangue (FUNASA, 1999). Os sintomas mais freqüentes na malária são febres e calafrios, que podem ser acompanhados por dores de cabeça, mialgia, fraqueza, náuseas e vômitos. Outros sintomas clínicos podem estar presentes como esplenomegalia, anemia, trompocitopenia, hipoglicemia, disfunção renal ou pulmonar e mudanças neurológicas. O quadro clínico depende da espécie infectante, nível da parasitemia e da resposta imune do indivíduo.

Infecções causadas por P. falciparum podem ser graves quando ocorrem alterações neurológicas (incluindo coma), falência renal aguda, hipoglicemia, edema pulmonar e/ou anemia grave. Anemia grave também 
pode ser uma complicação clínica causada por $P$. vivax. A infecção crônica por $P$. malariae pode levar a síndrome nefrótica que pode ser fatal.

A habilidade de invasão de eritrócitos de todas as idades causando altas parasitemias e a capacidade de aderir ao endotélio vascular, bem como aos eritrócitos não parasitados (formando rosetas) e à placenta são características da infecção por $P$. falciparum que favorecem a ocorrência de formas clínicas graves (HEDDINI, 2002).

A aderência de eritrócitos infectados é um fenômeno complexo envolvendo interações moleculares entre antígenos localizados nas protusões eletrodensas de eritrócitos parasitados como PfEMP1 (Plasmodium falciparum erytrocyte membrane protein 1) e receptores do hospedeiro, como CD36, Trombospondina (TSP), ICAM-I, VCAM, Eselectina, Sulfato de Condroitina A (CSA) (principal receptor de citoaderência na placenta), CD-21 e P-selectina. O seqüestro dos eritrócitos infectados por P. falciparum evita que sejam destruídos no baço (NEWBOLD et al, 1999; CHEN et al, 2000).

A obstrução vascular mecânica causada pela aderência de eritrócitos infectados ao endotélio vascular com a formação de rosetas é uma das causas da patogênese na malária grave. A resposta inflamatória de citocinas tais como TNF- $\alpha$ (Fator de Necrose Tumoral- $\alpha$ ) e IFN- $\gamma$ (Interferon- $\gamma$ ) produzidas por células $\mathrm{T}$ ativadas e macrófagos regulam a expressão de moléculas de adesão que participam do processo de aderência da PfEMP1 (HEDDINI, 2002). 


\section{IMUNIDADE NATURALMENTE ADQUIRIDA}

Em áreas de alta transmissão de malária, observa-se o desenvolvimento gradual de imunidade clínica nos indivíduos com múltiplas infecções pregressas. A aquisição deste tipo de proteção natural é lábil e é dependente da duração da exposição do indivíduo ao parasita (GREENWOOD, 1999), da exposição a variantes antigênicas múltiplas dos plasmódios e da maturação do sistema imune. Nos primeiros meses de vida, as crianças são protegidas da morbidade, provavelmente devido à transferência de anticorpos maternos (EDOZIEN et al, 1962; MCGREGOR, 1964) e à persistência da hemoglobina fetal (PASVOL et al, 1977). Após seis meses de vida, as crianças são suscetíveis à malária, conseqüentemente apresentam sinais e sintomas clínicos e altas parasitemias. A incidência de anemia grave e mortalidade alcançam índices máximos (GREENBERG et al, 1989; SNOW et al, 1994). Por volta dos cinco anos de idade as crianças começam a desenvolver imunidade antitóxica, que é a diminuição das manifestações clínicas da doença, mesmo com altas densidades parasitárias.

Os adultos, com exceção de gestantes, desenvolvem uma imunidade não esterilizante com níveis sub-patentes de parasitemias e sem sintomas da doença (GREENWOOD, 1987). As gestantes são suscetíveis à malária, especialmente na primeira gravidez, ocorrendo uma depressão transitória da imunidade celular. Existem também evidências de proteção em adultos não imunes, com exceção de crianças, após um ano de muita exposição, 
sugerindo um modo alternativo de aquisição de imunidade antimalárica (BAIRD, 1995; BAIRD 1998).

Em áreas de transmissão instável de malária, a população em geral não é imune, ocorrendo casos de doença clínica em adultos jovens, principalmente homens, provavelmente pela exposição ocupacional, e muitas infecções se tornam graves e complicadas. Os sintomas da doença podem surgir antes da parasitemia ser detectável microscopicamente, e qualquer parasitemia, mesmo muito baixa, pode implicar em doença.

Múltiplos mecanismos efetores tanto dependentes de anticorpos como não dependentes, são induzidos no complexo ciclo de vida do parasita em que cada estágio apresenta diferentes antígenos, e estão envolvidos na imunidade naturalmente adquirida, tais como: mecanismos efetores da imunidade anti-esporozoítos (anticorpos e citocinas produzidas por células T $\mathrm{CD}^{+}$), anticorpos contra estágios eritrocíticos e células $\mathrm{T}$ citotóxicos dirigidos contra estágios hepáticos.

\subsection{Imunidade específica no estágio pré-eritrocítico}

Foi demonstrada pela primeira vez, em 1979, a presença de anticorpos anti-esporozoítos, ou seja, anticorpos contra a membrana externa de esporozoítos de $P$. falciparum, em soros de indivíduos moradores na Gâmbia, Oeste da África, área com transmissão estável de malária. Os títulos desses anticorpos aumentam com a idade, em paralelo com a aquisição de resistência à infecção (NARDIN et al, 1979). 
Vários estudos posteriores têm mostrado que anticorpos contra diversas proteínas da superfície do esporozoíto podem imobilizar os esporozoítos e neutralizar sua infectividade, bloqueando a invasão do parasita nos hepatócitos (POTOCNJAK et al, 1980; STEWART et al, 1986; SINNIS \& NUSSENZWEIG, 1996).

Células $\mathrm{T} \mathrm{CD}^{+}$específicas para antígenos do estágio pré-eritrocítico quando ativadas têm ação citotóxica, destruindo o hepatócito infectado e secretam citocinas que atuam sobre os parasitas intracelulares (HOFFMAN \& FRANKE, 1994; GOOD \& DOOLAN, 1999). Existem evidências para o envolvimento de células $\mathrm{T} \mathrm{CD8}^{+}$na proteção, como: (a). a depleção in vivo de células $\mathrm{T} \mathrm{CD8}^{+}$anula proteção; (b). a transferência adotiva de células $\mathrm{T}$ $\mathrm{CD}^{+}$confere proteção a camundongos naïve; (c). camundongos transgênicos $\beta$-2- microglobulina ${ }^{-/}$(não expressam moléculas MHC classe I) não são protegidos pela imunização ativa ou pela transferência adotiva de células T esplênicas de camundongos imunes selvagens (WHITE et al, 1996).

As células $\mathrm{CD}^{+}$auxiliares específicas também exercem um papel importante na imunidade anti-esporozoíta com a secreção de citocinas como IFN- $\gamma$ que é um potente ativador de monócitos e macrófagos, induzindo aumento da fagocitose, morte dos parasitas, e secreção de citocinas, como IL-1 e IL-6, que inibem o desenvolvimento intra-hepático do parasita em humanos e murinos (HOFFMAN \& FRANKE, 1994). 


\subsection{Imunidade no estágio eritrocítico sexuado}

A imunidade contra os estágios eritrocíticos sexuados pode reduzir a infectividade dos gametas aos mosquitos e bloquear a transmissão da doença (CARTER \& CHEN, 1976).

Após a picada de um indivíduo infectado, os anticorpos contra antígenos da superfície dos gametas entram em contato com os gametas quando estes são liberados das hemácias do hospedeiro no intestino do mosquito. Os principais mecanismos efetores são mediados por anticorpos antigametócitos que bloqueiam a fertilização (READ et al, 1994) ou mediam lise dos gametas por complemento e por anticorpos anti-oocinetos que podem bloquear a passagem para o estômago (CARTER et al, 1989; SHAHABUDIN et al, 1993). Provavelmente, os gametócitos não ingeridos pelos mosquitos são removidos pelo sistema retículo-endotelial. Experimentos in vitro mostraram que TNF- $\alpha$ pode destruir gametócitos (NAOTUNNE et al, 1991).

\subsection{Imunidade no estágio eritrocítico assexuado}

A resposta imune contra os estágios eritrocíticos assexuados também envolve mecanismos dependentes e independentes de anticorpos e as células $\mathrm{T} \mathrm{CD}^{+}$têm um papel crucial na indução e na manutenção desta resposta.

Células $\mathrm{T} \mathrm{CD}^{+}$podem ser divididas em duas sub-populações, dependendo do perfil de secreção de citocinas: células "T helper 1" (Th1) e células "T helper 2" (Th2). As células Th1 induzem preferencialmente a resposta imune celular com produção de citocinas pró-inflamatórias, IL-2, 
IFN- $\gamma$, TNF- $\alpha$ IL-12, que levam à ativação de macrófagos e outras células efetoras. As células Th2 induzem preferencialmente a resposta imune humoral com produção das citocinas, IL-4, IL-5, IL-6, IL-10 e IL-13, que antagonizam a ação das citocinas pró-inflamatórias (ABBAS et al, 2000).

As células Th1 aumentam a produção de anticorpos citofílicos, principalmente IgG2a e IgG3 em camundongos e IgG1 e IgG3 em humanos. As células Th2 promovem a produção de subclasses de $\lg$ que estão associadas a alergias e infecções helmínticas, tais como lgG1 em camundongos e lgG4 em humanos (ABBAS et al, 2000).

A existência de subpopulações de células $\mathrm{T} \mathrm{CD}^{+}$específicas para antígenos de plasmódios tem sido demonstrada in vitro, tanto em camundongos como em humanos. O estudo da reatividade de clones de células $\mathrm{CD}^{+}$respondedores a antígenos eritrocíticos do parasita em camundongos infectados por $P$. chabaudi mostrou heterogeneidade consistente com a idéia de dois subtipos de células CD4 ${ }^{+}$diferentes funcionalmente. Células derivadas de infecção primária recente secretaram IL-2 e IFN- $\gamma$ após o estímulo antigênico in vitro, portanto, apresentavam um repertório de citocinas típico de células $\mathrm{CD}^{+}$Th1 e contribuíram para o clareamento precoce da parasitemia. Com o decorrer da infecção, foi observado um declínio da subpopulação Th1 e aumento de células tipo Th2, ou seja, produtoras de IL-4 e com função de células auxiliares da síntese de anticorpos in vitro, agindo no controle da infecção e clareamento da parasitemia (TAYLOR-ROBINSON \& PHILIPS, 1993). 
O curso da infecção por plasmódios é dependente do equilíbrio entre as citocinas secretadas por vários tipos de células quando ativadas. A exacerbação da produção destes mediadores pode causar efeitos sistêmicos tais como anemia grave e malária cerebral (MCGUIRE et al, 1994; TROYEBLOMBERG et al, 1999; LUTY et al, 2000; MALAGUARNERA et al, 2002).

No quadro 1 sumarizamos as ações das principais citocinas produzidas durante a resposta imune à infecção por plasmódios.

\section{Resposta Humoral no estágio eritrocítico assexuado}

Um dos aspectos mais característicos da infecção por plasmódios é a hipergamaglobulinemia, marcada pela elevação dos níveis séricos de $\lg \mathrm{M}$ e IgG. Contudo apenas 5 a $10 \%$ dessas imunoglobulinas reagem com antígenos do parasita, sendo os demais anticorpos não específicos ao plasmódio, como anticorpos heterófilos e auto-anticorpos contra hemácias, linfócitos, complemento, ou fator reumatóide e fatores antinucleares. Esta reatividade não específica ocorre provavelmente pela ação mitogênica de antígenos solúveis de plasmódios que leva à ativação policlonal de linfócitos B (FERREIRA et al, 1988).

Os anticorpos específicos podem ser dirigidos contra antígenos dos diferentes estágios eritrocíticos assexuados (esquizontes, trofozoítos jovens e maduros). 
Quadro 1. Papel das principais citocinas produzidas durante a resposta imune do hospedeiro à infecção por plasmódios (baseado em RICHARDS, 1997; MALAGUARNERA et al, 2002).

\begin{tabular}{|c|c|c|}
\hline Citocina & Recurso & Função \\
\hline TNF- $\alpha$ & $\begin{array}{l}\text { Produzido por macrófagos } \\
\text { e monócitos }\end{array}$ & $\begin{array}{l}\text { Aumenta a capacidade fagocitária de monócitos e } \\
\text { regula produção de IL-12 dos macrófagos. Otimiza } \\
\text { produção de NO, e juntos são responsáveis pelo } \\
\text { clareamento da parasitemia e pela resolução das } \\
\text { febres, mas em excesso causa patogênese. regula } \\
\text { produção de IL- } 12 \text { dos macrófagos. }\end{array}$ \\
\hline $\mathrm{IFN}-\gamma$ & $\begin{array}{l}\text { Produzido por células T } \\
\mathrm{CD8}^{+} \text {e T CD4 }{ }^{+} \text {e }\end{array}$ & $\begin{array}{l}\text { Ativa macrófagos a liberarem TNF- } \alpha \text {, TGF- } \beta \text {, IL-1, IL- } 6 \text {, } \\
\text { ROI, NOI que agem individualmente ou conjuntamente } \\
\text { para matar e inibir o crescimento do parasita. Em } \\
\text { excesso leva à patogênese }\end{array}$ \\
\hline Linfotoxina & Produzida por células Th1. & $\begin{array}{l}\text { Gera NO, induz hipoglicemia e aumento dos níveis de } \\
\text { IL-6. }\end{array}$ \\
\hline $\mathrm{IL}-1$ & $\begin{array}{l}\text { Produzida por monócitos/ } \\
\text { macrófagos, NK, células } B \text {, } \\
\text { células dendríticas }\end{array}$ & $\begin{array}{l}\text { Estimula a proliferação de células } \mathrm{T} \text { e induz a } \\
\text { expressão de IL-2 e produção de IL-2. Induz ROI in } \\
\text { vivo. Aumenta a expressão de células endoteliais e } \\
\text { aumenta a habilidade de células endoteliais de cultura } \\
\text { a se ligarem a eritrócitos infectados. }\end{array}$ \\
\hline IL-2 & $\begin{array}{l}\text { Produzida por células } \\
\text { Th1 e CD8 }{ }^{+} \text {ativadas }\end{array}$ & $\begin{array}{l}\text { Fator de crescimento para linfócitos } \mathrm{T} \text { e } \mathrm{NK} \text { e } \\
\text { importante na ativação destas células e de macrófagos }\end{array}$ \\
\hline IL-4 & $\begin{array}{l}\text { Produzida por células Th2 } \\
\text { e basofilos/mastócitos } \\
\text { ativados. }\end{array}$ & $\begin{array}{l}\text { Induz a mudança da resposta imune para cima } \\
\text { resposta Th2 e inibe a Th1, diminuindo a produção e } \\
\text { atividade de IFN- } \gamma \text {. Importantes na resposta de } \\
\text { anticorpos A produção de IL-4 por células Th2 } \\
\text { estimuladas com antígenos de plasmódios in vitro } \\
\text { aumenta as concentrações de anticorpos. }\end{array}$ \\
\hline IL-5 & $\begin{array}{l}\text { Produzida por células Th2 } \\
\text { e basofilos/mastócitos }\end{array}$ & $\begin{array}{l}\text { Fator de estimulação de colônias, diferenciação e } \\
\text { ativação de eosinófilos, que estão associados com } \\
\text { morte de P.falciparum }\end{array}$ \\
\hline IL-6 & $\begin{array}{l}\text { Produzida por macrófagos } \\
\text { e células Th2 }\end{array}$ & $\begin{array}{l}\text { Inibe crescimento de parasitas por meio de } \mathrm{NOI} \text { e/ou } \\
\mathrm{ROI} \text {, correlacionada com níveis de TNF e densidade } \\
\text { parasítica e gravidade da doença na malária. }\end{array}$ \\
\hline IL-8 & $\begin{array}{l}\begin{array}{l}\text { Produzida macrófagos, } \\
\text { neutrófilos, }\end{array} \\
\text { fibroblastos, } \\
\text { cel. } \\
\begin{array}{l}\text { queratinócitos, Noteliais, } \\
\text { células T }\end{array}\end{array}$ & $\begin{array}{l}\text { Pode se ligar ao antígeno duffyl receptor de } \\
\text { quimiocinas na hemácia, inibe competitivamente a } \\
\text { ligação e invasão de } P \text {. knowlesi em hemácias, mas } \\
\text { não tem nenhum efeito sozinho no parasita. É um fator } \\
\text { de ativação de neutrófilo. }\end{array}$ \\
\hline IL-12 & $\begin{array}{l}\text { Produzida por fagócitos } \\
\text { mononucleares e células } \\
\text { dendríticas }\end{array}$ & $\begin{array}{l}\text { Promove a diferenciação de células T para o tipo Th1 e } \\
\text { induzindo células Th1 a produzirem IFN- } \gamma \text {. Modula a } \\
\text { atividade de macrófagos. }\end{array}$ \\
\hline IL-18 & $\begin{array}{l}\text { Produzida por macrófagos, } \\
\text { células de Kupffer, } \\
\text { queratinócitos, } \\
\text { osteoclastos }\end{array}$ & $\begin{array}{l}\text { Ativa macrófagos a produzirem TNF- } \alpha, \mathrm{IFN}-\gamma \text {, IL-1 e } \\
\text { induz a citoxicidade de células NK e aumenta a } \\
\text { diferenciação de células T para o tipo Th1. O } \\
\text { sincronismo na produção entre IL-18 e IL-12 apresenta } \\
\text { um papel importante na defesa contra o plasmódio. }\end{array}$ \\
\hline GM-CSF & $\begin{array}{l}\text { Produzida por linfócitos T, } \\
\text { fagócitos mononucleares, } \\
\text { células } \quad \text { endoteliais, } \\
\text { fibroblastos. }\end{array}$ & 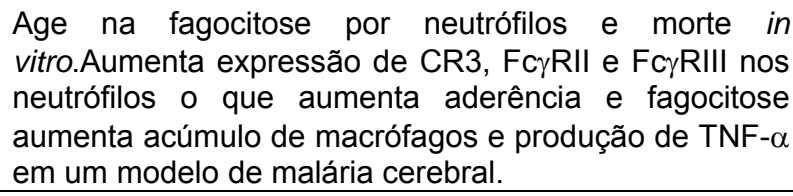 \\
\hline TGF- $\beta$ & $\begin{array}{l}\text { Produzido macrófagos, } \\
\text { células NK, T e B }\end{array}$ & $\begin{array}{l}\text { Ativa macrófagos/ monócitos e induz a fagocitose de } \\
\text { eritrócitos parasitados e a morte dos parasitas } \\
\text { ingeridos. }\end{array}$ \\
\hline
\end{tabular}


Anticorpos são geralmente marcadores de infecção. A convencional evolução em relação à resposta de anticorpos a patógenos induz uma resposta inicial com a produção de anticorpos lgM, que é substituída pela produção de outras classes como $\lg G$, $\lg A$, $\lg E$, devido à mudança da cadeia pesada da imunoglobulina com a maturação da resposta de anticorpos (MANIS et al,2002). Além de marcadores de infecção, também são efetores na proteção em muitas circunstâncias da infecção.

Existem evidências in vitro que anticorpos podem mediar proteção contra estágio eritrocítico de P. falciparum (BOUHAROUN-TAYOUN et al, 1990).

O papel dos anticorpos antiformas eritrocitárias de plasmódios, principalmente da classe IgG, na imunidade protetora tem sido demonstrado por: (a). transferência passiva de imunidade por soro de doadores imunes a recipientes não imunes (homem, macacos, e alguns roedores) (BROWN, 1969); (b). transferência adotiva de células B (GRAVELY \& KREIER, 1976); (c). suscetibilidade à infecção aumentada de aves bursectomizadas (RANK \& WEINDANZ, 1976) e camundongos mu suprimidos (ROBERTS \& WEINDANZ, 1978); (d). inibição in vitro da invasão dos eritrócitos por merozoítos e do desenvolvimento intra-eritrocítico por anticorpos neutralizantes (MITCHELL et al, 1976; BROWN et al, 1983) e (e). Mediação da opsonização de eritrócitos infectados facilitando a fagocitose dos mesmos por monócitos ou polimorfonucleares (KHUSMITH \& DRUILHE, 1983; GROUX \& GYSIN, 1990). 
Anticorpos contra formas eritrocitárias também estão envolvidos na inibição do crescimento do parasita dependente de células e anticorpos, numa reação conhecida como $\mathrm{ADCl}$ (antibody-dependent cellular inhibition) (CELADA et al, 1983).

Dentre os anticorpos IgG, as diferentes subclasses podem exercer diferentes papéis na resposta imune aos plasmódios. Vários estudos mostram que anticorpos protetores agem sinergisticamente com outras células efetoras, como monócitos e outros leucócitos (BOUHAROUNTAYOUN et al, 1990; GROUX \& GYSIN, 1990), ou seja, devem ter ação citofílica.

Anticorpos citofílicos IgG1 e IgG3 podem se ligar aos antígenos de superfície do eritrócito (opsonização) e auxiliar na fagocitose via receptores FcyRI e FcyRII, ou participar da inibição celular dependente de anticorpos (ACDI), responsável pelo aparecimento da forma "crisis" do parasita (JENSEN et al, 1982; BOUHAROUN-TAYOUN et al, 1992; GREENBERG \& SLVERSTEIN, 1993) ou ainda participam da citoxicidade dependente de anticorpos (ACCD). O efeito neutralizante na inibição celular dependente de anticorpo (ACDI) é mediado principalmente por fatores solúveis liberados pelos monócitos. Esses fatores solúveis, provavelmente TNF- $\alpha$ e óxido nítrico, bloqueiam a divisão nuclear dos parasitas do estágio intraeritrocítico (BOUHAROUN-TAYOUN et al, 1995). O predomínio de anticorpos citofílicos em áreas endêmicas é associado com baixa parasitemia (ARIBOT et al, 1996) ou baixo risco de ataque clínico da malária (SHI et al, 1996). 
Anticorpos não citofílicos, IgG2 e IgG4, podem inibir as respostas efetoras dos anticorpos citofílicos pela competição pelos mesmos domínios ou por domínios vizinhos, desencadeando um desequilíbrio e conseqüentemente sendo responsáveis pela formação de um status de resistência e/ou suscetibilidade à malária (GROUX \& GYSIN, 1990; BOUHAROUN-TAYOUN \& DRUILHE, 1992).

$\mathrm{Na}$ figura 2 temos um esquema dos possíveis mecanismos de clareamento dos eritrócitos infectados por $P$. falciparum, mediados por anticorpos citofílicos, que têm sido demonstrados in vivo e ex vivo: fagocitose imune e ACDI. Nos dois mecanismos, anticorpos específicos contra os eritrócitos infectados formam uma ponte entre o eritrócito infectado e a célula efetora, que deve expressar receptores para $F_{c}$ de imunoglobulina (FcRs) que se liguem bem a imunecomplexos. Na fagocitose imune, os eritrócitos infectados ligados pelos anticorpos às células efetoras, por exemplo, macrófagos, são fagocitados. Na ACDI, anticorpos citofílicos IgG1 e principalmente IgG3 ligam o eritrócito infectado a uma célula efetora (monócito, macrófago ou neutrófilo), que então produz um fator lítico ainda não identificado, mas que não é TNF- $\alpha$ nem linfotoxinas. O uso preferencial de um desses mecanismos estaria sendo dirigido pela natureza do antígeno (GARRAUD et al, 2003).

Em camundongos, anticorpos citofílicos, IgG2a, estão associados com proteção contra a infecção causada por Plasmodium (SMITH et al, 1997; MATSUMOTO et al, 2000; SU \& STEVENSON, 2000; SMITH \& TAYLORROBINSON, 2003). IgG2a é predominante durante a fase aguda, em 
camundongos infectados com Plasmodium chabaudi chabaudi AS, seguida por uma resposta IgG1, durante a fase crônica, demonstrando a dicotomia da resposta imune de células Th1/ Th2 (TAYLOR-ROBINSON, 2002). IgG1 e IgG2 podem conferir proteção contra infecção letal com Plasmodium yoelli YM em camundongos imunizados com proteína principal da superfície do merozoíta 19 (Merozoite Surface Protein 19 - MSP ${ }_{19}$ ) (HIRUNPETCHARAT et al, 1997). A transferência passiva de anticorpos lgG3 anti - $\mathrm{MSP}_{19}$ para recipientes naïve, torna-os capazes de resolver a infecção causada por Plasmodium yoelii (MAJARIAN et al, 1984; VUKOVIC et al, 2000).

A associação de anticorpos citofílicos com proteção não é observada em todos os estudos epidemiológicos, pois pode depender da cepa, antígenos do parasita utilizados na análise ou fatores genéticos do hospedeiro (AUCAN et al, 2000). Em particular, anticorpos lgG3 direcionados para os antígenos da superfície do eritrócito infectado por trofozoítos jovens de $P$. falciparum (RESA -Ring Erythrocyte Surface Antigen), antígeno MSP-1 de P. falciparum (Merozoite Surface Protein-1) e exoantígenos não estava associado à proteção em Madasgacar e Papua Nova Guiné (SHI et al, 1996), enquanto extrato bruto do estágio eritrocítico de $P$. falciparum estava associado com proteção clínica no Senegal (ARIBOT et al, 1996; SARTHOU et al, 1997). 


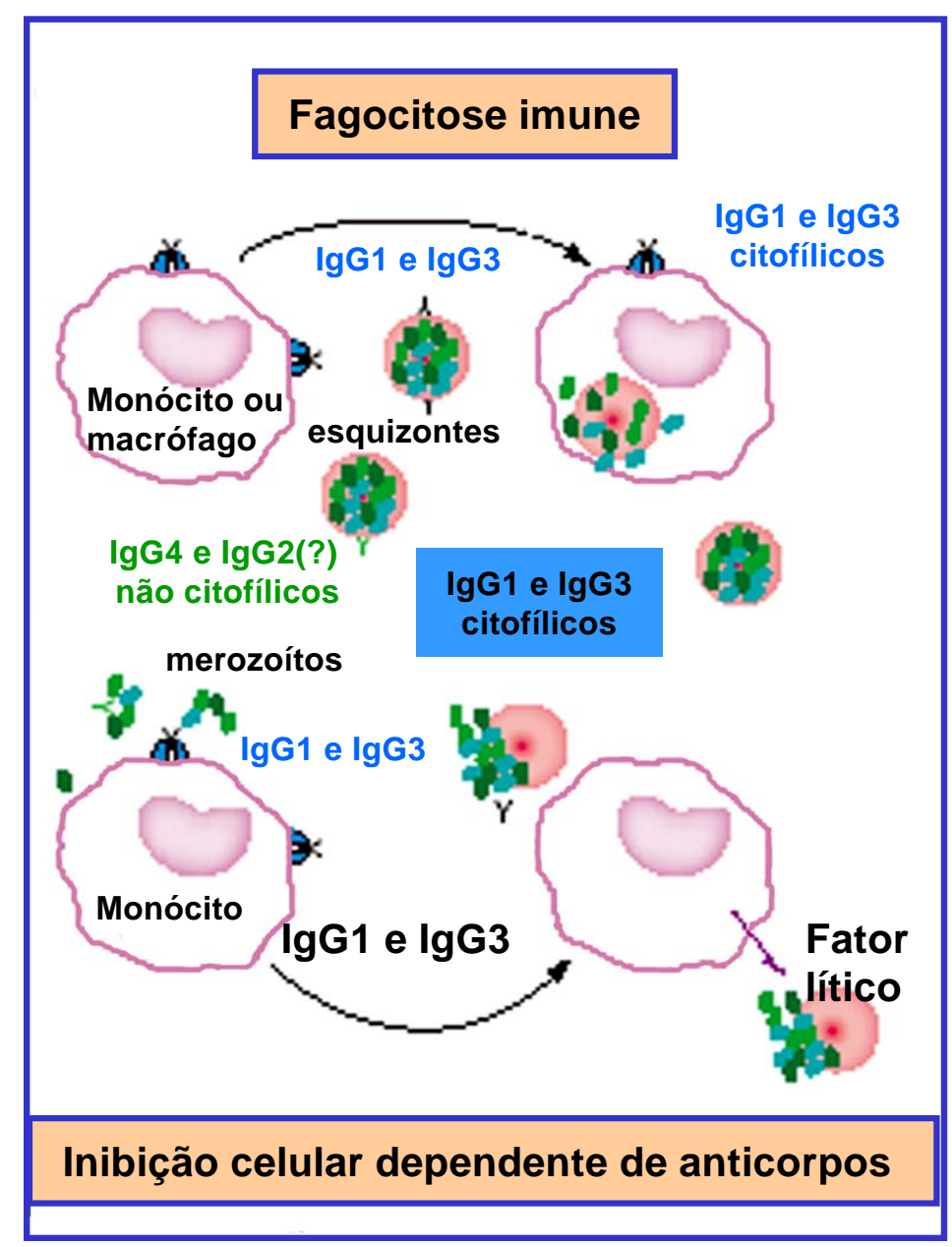

Fig. 2. Possíveis mecanismos de clareamento de eritrócitos infectados por $P$. falciparum mediados por anticorpos citofílicos (Adaptado de Garraud, 2003).

Do mesmo modo, os níveis de IgG1 para extrato bruto, RESA e MSP1 de $P$. falciparum atingiam níveis mais altos em indivíduos não protegidos do que em indivíduos protegidos, em Madasgacar (DUBOIS et al, 1993), enquanto IgG1 contra exoantígenos de $P$. falciparum estava associado com proteção clínica (CHUMPITAZI et al, 1996). 
Na malária, Aucan et al. (2000) observaram uma associação de altos níveis de anticorpos IgG2 anti - RESA e MSP2, com baixo risco de infecção, em uma população de área holoendêmica, Burkina Faso, e sugeriram que nessa população, anticorpos lgG2 estariam agindo como citofílicos e contribuindo para o clareamento da parasitemia. Assim, eles investigaram a ocorrência na população estudada do polimorfismo H131 no gene do receptor FcyRIIA nas células fagocitárias, que codifica um receptor capaz de se ligar à fração $F_{c}$ de $\lg G 2$, conferindo-Ihe ação citofílica (maiores detalhes abaixo). Eles encontraram o polimorfismo H131 em $70 \%$ dos indivíduos, o que estaria fortalecendo a participação de $\lg G 2$ na proteção contra a malária.

Deloron et al. (1997) mostraram uma associação entre altos níveis de lgG2 e baixo risco de infecção por $P$. falciparum, em crianças de 6 meses. Os níveis de anticorpos lgG4 não citofílicos foram correlacionados com risco de ataque clínico da malária, pois podem bloquear a $A D C l$ (AUCAN et al, 2000).

A presença de anticorpos IgE anti-plasmódios, em população de área endêmica e o papel destes anticorpos em proteção e/ ou patogênese não estão bem esclarecidos. Desowitz (1989) estudando indivíduos adultos moradores de região holoendêmica, Nova Guiné, encontrou aproximadamente $30 \%$ de positividade para IgE anti- Plasmodium falciparum. Em outro estudo, com amostras pareadas de soro e cordão, o mesmo autor observou correlação inversa entre as taxas de parasitemia na placenta, paridade e a soropositividade maternal para lgE específica 
(DESOWITZ et al, 1993). Investigações imunohistoquímicas também revelaram a deposição de $\lg E$ na placenta, inibindo o crescimento parasitário no espaço entre as vilosidades (MAENO et al, 1993). Perlmann et al. (1994), encontraram elevados níveis de anticorpos lgE total e anticorpos lgE específicos anti- $P$. falciparum em, respectivamente $85 \%$ e quase $60 \%$ da população de áreas de alta endemicidade na África e Ásia. Por "Immunobloting", eles observaram que, diferentemente dos anticorpos IgG que reagem com um grande número de bandas, os anticorpos IgE reagem contra algumas bandas apenas, com o aparecimento precoce de reatividade contra um antígeno de $45 \mathrm{kDa}$, que também reage com IgG4. Em geral, níveis elevados de $\operatorname{lgE}$ refletem um desequilíbrio nas células $\mathrm{T}$ CD4 ${ }^{+}$ auxiliares (Th), com polarização da resposta imune para Th2 que produzem citocinas, tais com IL-4 e IL-13, que são responsáveis pela mudança de $\lg \mathrm{M} / \lg$ para $\lg \mathrm{E}$. A produção de IL-4 pelas células $\mathrm{T}$ CD4 ${ }^{+}$de indivíduos primo-infectados naturalmente expostos à infecção está associada com elevados níveis de anticorpos específicos a antígenos de $P$. falciparum (TROYE-BLOMBERG et al, 1990).

Helmby e Troye-Blomberg (2002) encontraram elevados níveis de IL-4 e IgE em camundongos BALB/c infectados com $P$. chabaudi chabaudi e os níveis elevados de lgE não estavam associados com patologia, mas particularmente com o desenvolvimento de imunidade. Camundongos C57BI/6 não secretaram IL-4, mas houve um aumento significante nos níveis de IgE demonstrando que outros fatores, como IL-13 ou mecanismos independentes de IL-4 poderiam induzir a produção de IgE. Embora 
camundongos C57BI/6 não tivessem desenvolvido elevados níveis de lgE, estavam completamente protegidos contra malária, indicando que anticorpos $\operatorname{lgE}$ não são cruciais para a imunidade nessa linhagem de camundongos em particular.

Linfoma de Burkitt induzido pelo vírus Epstein Barr, carcinoma nasofaríngeo, leucemia linfática aguda e linfoma não Hodgkin e não Burkitt são mais freqüentes em pacientes com malária. Um aumento nessas formas de câncer tem sido atribuído a uma mudança no padrão para Th2, e essa mudança pode ser sugerida por aumento de anticorpos $\lg E$, o que é observado em indivíduos de áreas endêmicas de malária, tanto em relação à lgE total como lgE específico e subclasses lgG2 e lgG4 (TAYLORROBINSON, 1998).

Algumas evidências sugerem o envolvimento dos anticorpos IgM anti P. falciparum, na proteção contra a malária, como: (a). camundongos incapazes de produzir IgM, por uma deficiência de células B recessiva ligada ao X, são suscetíveis a Plasmodium yoelii (JAYAWARDENA et al, 1979); (b). adição de anticorpos IgM monoclonais aumentaram as propriedades protetoras de uma vacina de malária (HARTE et al, 1983); (c). estudos em áreas de alta endemicidade têm mostrado que enquanto anticorpos lgG apresentam correlação positiva com os níveis de parasitemia, os anticorpos IgM, se relacionam com redução de parasitemia em Burkina Faso (BOUDIN et al, 1993).

Luty et al. (1994) estudando moradores no sudeste do Gabão observaram níveis elevados de anticorpos IgM específicos a exoantígenos 
em indivíduos com parasitemia, contradizendo os achados de Boudin et al. Essa discrepância pode ser resultante das diferenças na endemicidade e da dinâmica de transmissão entre as áreas de estudo.

Em Dielmo, no Senegal, os níveis dos anticorpos IgM estavam gradualmente e consistentemente aumentados durante a estação de alta transmissão (ARIBOT et al, 1996). Isto sugere um contato recente com novos isolados de parasitas e/ou reconhecimento imune destes novos isolados de parasitas, pelos hospedeiros, e desencadeando uma resposta imunológica independente de células T (LUTY et al, 1994; NTOUMI et al, 1995).

Estudos, de acompanhamento sorológico de indivíduos com malária falciparum sob tratamento com terapêutica específica, realizados em nosso laboratório, mostraram que tanto os níveis iniciais de anticorpos da classe lgG, como o nível máximo de $\lg \mathrm{M}$ atingido durante o acompanhamento apresentaram associação inversa e estatisticamente significativa com o tempo de clareamento da parasitemia (DURLACHER, 1998).

Muito pouco se sabe sobre os anticorpos IgA na malária. Um estudo do perfil sorológico de grupos populacionais, bem definidos, de área de transmissão moderada de malária, mostrou maior freqüência de anticorpos IgA no grupo de indivíduos primo-infectados (ÁVILA et al, 1993; ÁVILA et al, 1999). 


\section{POLIMORFISMO DO GENE DO RECEPTOR FC $\gamma$ RIIA ${ }^{131}$}

Os receptores para região $\mathrm{Fc}$ de imunoglobulinas $(\mathrm{FcR})$ estão presentes na membrana de células acessórias e mediam respostas funcionais como: fagocitose, citoxicidade dependente de anticorpo (ADDC), produção de citocinas, degranulação, apresentação de antígeno e regulação na produção de anticorpos. Os receptores FcR são expressos em macrófagos, monócitos, neutrófilos, eosinófilos, células dendríticas, células NK, células $T$ e $B$, plaquetas e células endoteliais e a sua expressão é regulada por citocinas ou fatores de crescimento. A ativação das células acessórias ocorre com a agregação dos FcRs pela ligação a múltiplas regiões Fc de moléculas de anticorpos ligadas a um microrganismo. (revisado em VAN SORGE et al, 2003).

Os FcRs pertencem à superfamília de imunoglobulinas (lg), portanto com domínios Ig na superfície extracelular os quais eles utilizam para se ligarem às regiões $F_{c}$ e outras cadeias que são requeridas para transporte para a superfície celular e para transdução de sinais quando se liga à região Fc. São moléculas estrutural e bioquimicamente distintas, que diferem na distribuição celular e na afinidade para os diferentes isotipos de imunoglobulina, FcyR para $\lg G$, FceR para $\lg E$ e FcoR para $\lg A$. Os

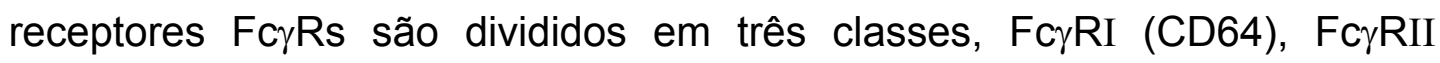
(CD32) e FcyRIII (CD16). Os Fc $\gamma R$ são ainda divididos em FcyRII (FcyRIIA, Fc $\gamma$ RIIB e FcyRIIC) e Fc $\gamma$ RIII (Fc $\gamma$ RIIIA e Fc $\gamma$ RIIIB) (RAVETCH \& KINET, 1991). Na figura 3 mostramos os diferentes $F c \gamma R$, as células que os expressam e as suas especificidades isotípicas. 


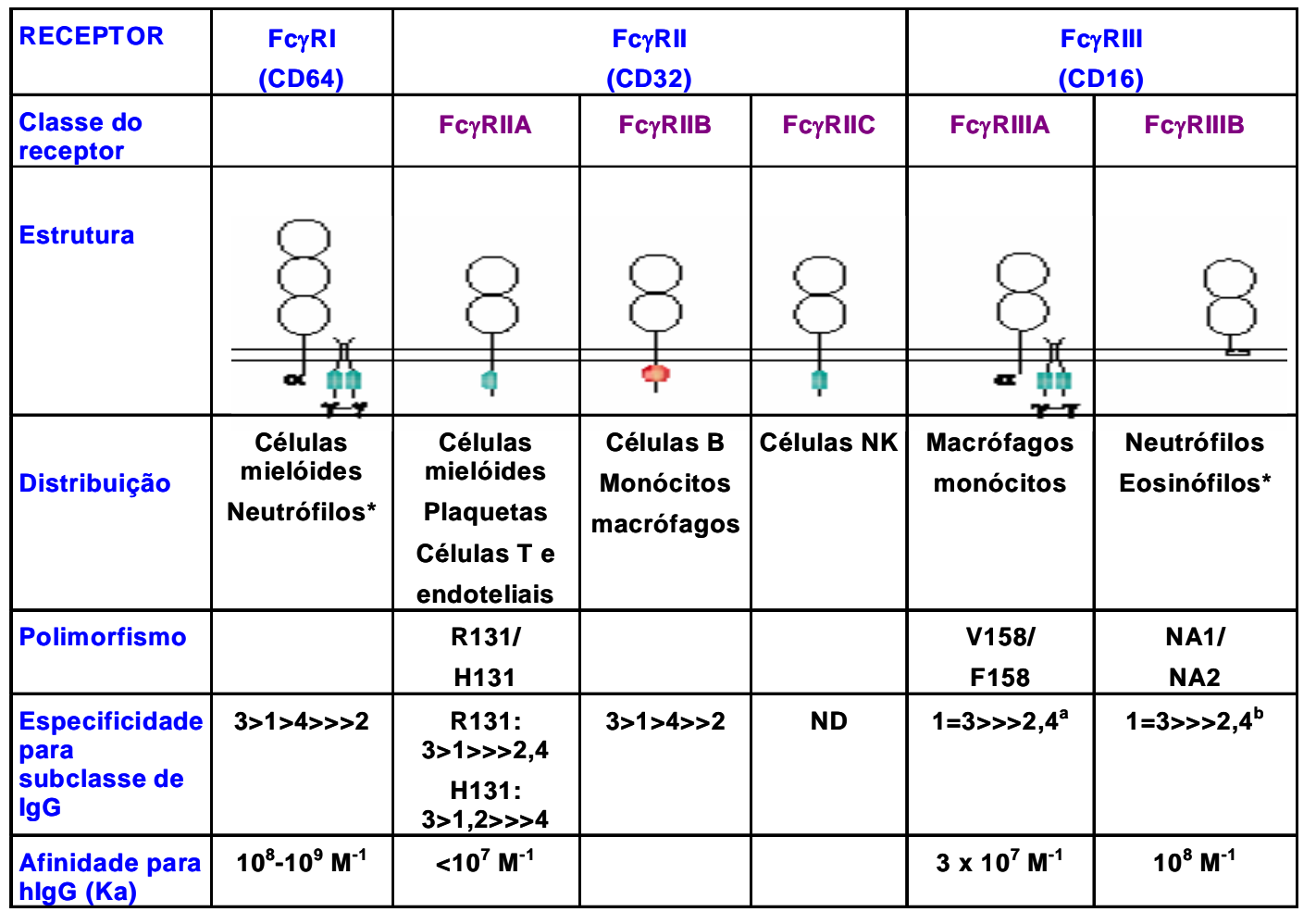

Fig. 3. Estruturas e características dos diferentes receptores para a região $F_{c}$ de $\lg (\mathrm{Fc} \gamma \mathrm{R})$ : distribuição celular, polimorfismos descritos, especificidades isotípicas e afinidade. ND= não determinado; * células que apresentam apenas após indução (baseado em FOSSATI et al, 2001; VAN SORGE et al, 2002, PLEASS \& WOLF, 2001)

Como podemos observar na figura 3, em geral, os receptores FcyR não se ligam à região $F_{c}$ de $\lg G 2$ ou o fazem com muito baixa afinidade. Entretanto, Warmerdam et al. (1991) detectaram um polimorfismo no gene do receptor FcyRIIA, uma mudança de arginina $(R)$ para histidina $(H)$ na posição 131, que o capacita a se ligar na cadeia pesada de IgG2 humana. Este polimorfismo (H131) tem sido implicado em muitas desordens de defesa do hospedeiro, doenças imunohematológicas e doenças autoimunes sistêmicas (JIANG et al, 1996). O alelo FcyIIA-R ${ }^{131}$ está associado ao 
aumento da suscetibilidade a infecções causadas por bactérias encapsuladas tais como Neisseria meningitidis, Streptococcus pneumoniae e Haemophilus influenzae (PLEASS \& WOOF, 2001).

Na malária, Shi et al. (2001) observaram que crianças do Quênia que apresentavam alelo homozigoto $\mathrm{Fc} \gamma \mathrm{IIA}-\mathrm{R}^{131}$ reportavam apresentavam menor risco de altas parasitemias de $P$. falciparum quando comparadas a crianças com o alelo heterozigoto $\mathrm{Fc} \gamma \mathrm{IIA}-\mathrm{H} / \mathrm{R}^{131}$, sugerindo um papel protetor deste genótipo. Embora não tenha sido observada diferença significante nas crianças que apresentavam o alelo homozigoto Fc $\gamma$ IIA-H ${ }^{131}$ em relação ao risco de infecção.

Como citado acima, também Aucan et al. (2000) observaram baixo risco de infecção em uma população de Burkina Faso com alta freqüência do polimorfismo $\mathrm{H} 131$ e ainda associado a altos níveis de anticorpos lgG2 anti RESA e MSP2.

Mais recentemente, Cooke et al. (2004) encontraram associação da presença do alelo homozigoto Fc $\gamma$ IIA $-\mathrm{H}^{131}$ a um aumento de suscetibilidade à malária grave no oeste da África. Mas, neste trabalho não foram analisados os níveis de anticorpos lgG2. 
Baseado no exposto até aqui, fica clara a importância do estudo das diferentes classes de anticorpos na resposta imune humoral a plasmódios, desde que mecanismos efetores dependentes de anticorpos têm significado em proteção na malária.

Muitos dos estudos existentes nessa área foram feitos apenas com a pesquisa de anticorpos IgG e mais recentemente, têm sido bastante estudadas as subclasses de $\operatorname{lgG}$. Em menor freqüência encontramos os estudos dos anticorpos lgM e IgE. Também pouco se conhece sobre a avidez ou afinidade funcional das diferentes classes e subclasses de anticorpos a antígenos de plasmódios.

Ainda, a grande maioria das investigações foi feita com amostras de soro de populações de áreas de alta endemicidade de malária, onde é muito claro o desenvolvimento de imunidade naturalmente adquirida. Estudos semelhantes em áreas com transmissão instável de malária são raros.

No presente trabalho, fizemos um amplo estudo do perfil sorológico da malária humana em indivíduos moradores em área endêmica com transmissão instável de malária na Amazônia Brasileira, avaliando não apenas a quantidade, mas também a qualidade dos anticorpos contra formas eritrocitárias de P.falciparum.

A determinação de todas as classes e subclasses de anticorpos em uma mesma população bem definida clinica, parasitológica e epidemiologicamente, pode fornecer informações importantes para um melhor entendimento do envolvimento dos anticorpos contra formas eritrocitárias no desenvolvimento de imunidade naturalmente adquirida mesmo em áreas com transmissão instável. 
II. OBJETIVOS 


\section{GERAL:}

Estudar o padrão de resposta dos anticorpos IgG e subclasses, IgE, IgM e IgA contra antígenos de formas eritrocitárias de Plasmodium falciparum de indivíduos naturalmente expostos à malária no Brasil.

\section{ESPECÍFICOS:}

1. Padronizar técnicas imunoenzimáticas para a pesquisa das classes de anticorpos $\lg E$, IgA e $\lg M$ e das subclasses $\lg G 1, \lg G 2$, $\lg G 3$ e lgG4 anti-formas eritrocitárias de P.falciparum e da avidez das subclasses de IgG.

2. Aplicar as técnicas padronizadas em amostras de soro de grupos bem definidos clínica, parasitológica e epidemiologicamente de indivíduos expostos naturalmente à infecção por plasmódios em áreas endêmicas de malária no Brasil.

3. Analisar os resultados obtidos em relação à presença ou não de infecção, às diferentes formas clínicas de malária e às variáveis preditoras de exposição à malária.

4. Determinar a presença do polimorfismo $\mathrm{H} 131$ do receptor Fc $\gamma$ RIIA em um determinado número de amostras de indivíduos da área endêmica. 


\section{1. Áreas de Estudo}

\subsection{Peixoto de Azevedo, MT.}

A cidade de Peixoto de Azevedo fica localizada na região norte do Estado do Mato Grosso à aproximadamente $700 \mathrm{~km}$ da capital, Cuiabá. O clima da região é equatorial quente e úmido, característico de floresta tropical, com estação chuvosa de novembro a abril (temperatura entre 21 a $34^{\circ} \mathrm{C}$ ) e estação seca de maio a outubro (temperatura entre 17 a $34^{\circ} \mathrm{C}$ ). $\mathrm{Na}$ época em que as amostras foram coletadas a transmissão de malária era perene, com um aumento durante a estação chuvosa.

Com o surgimento dos garimpos nas décadas de 70 e 80 ocorreram intensos fluxos migratórios para a região de indivíduos do norte, nordeste e sul do país, levando a um aumento no número de casos de malária, sem possibilidade do controle da doença. A população de Peixoto de Azevedo, de acordo com o senso de 1996, era de 29.237 habitantes.

Mato Grosso teve 59.089 e 37.638 casos de malária relatados em 1995 e 1996, respectivamente, ocupando em 1996, o primeiro lugar em índice de lâminas positivas (40,3\%). Em 1996, foram examinadas 32.072 lâminas nos municípios de Peixoto de Azevedo e Matupá, das quais 7.641 foram positivas para malária (24\%). A espécie predominante nos municípios foi $P$. vivax com $56,3 \%$ de positividade (4.301 casos), seguido pelo $P$. falciparum com 43,4\% (3.317 casos) e apenas $0,3 \%$ de positividade para malária mista (23 casos).

O principal transmissor de $P$. falciparum na região de Peixoto de Azevedo era o mosquito Anopheles darlingi, que apresentava índice de 
picadas por homem por hora de 13,5 nas regiões de garimpo e 3,1 na região periurbana.

Atualmente com o desaparecimento dos garimpos, tende a surgir uma nova situação epidemiológica de malária na região. A atividade agrícola aumentou com o incentivo dado pela administração municipal ao pequeno produtor e culminou no assentamento de colonos às margens da $B R-080$, local hoje denominado "P.A. Cachimbo" ou "Gleba Leonislândia".

\subsection{Manaus, AM.}

Amostras colhidas de pacientes admitidos na Unidade de Alto Risco (UAR) da Fundação de Medicina Tropical de Manaus (FMT/IMT-AM). Na FMT/IMT-AM, os sintomas clínicos mais freqüentes de malária complicada e aceitos como indicativos de terapia intensiva e admissão na UAR: sinais de colapso circulatório, insuficiência renal aguda, insuficiência respiratória aguda, distúrbio metabólico grave (LACERDA et al, 2001).

\section{Casuística}

2.1. Amostras de soros-padrão positivos $(n=12)$ e negativos $(n=12)$ para anticorpos anti-formas eritrocitárias de P.falciparum para padronização dos testes imunoenzimáticos para pesquisa de anticorpos $\lg E$, $\lg M$, IgA e subclasses de IgG. 
2.2. Amostras de soro de indivíduos residentes em áreas endêmicas de malária analisadas para a pesquisa das imunoglobulinas $\lg \mathrm{E}, \lg \mathrm{A}, \lg \mathrm{M}$ e subclasses $\lg G 1, \lg G 2, \lg G 3$ e $\lg G 4(n=270)$.

= 233 amostras de soro de indivíduos com resultado de plasmódio positivo pela gota espessa e/ou $\mathrm{QBC}^{\circledR}$

- 153 P. falciparum

- 27 P. falciparum e P. vivax

- 51 P.vivax

- 2 P. malariae

Dessas 70 amostras eram de indivíduos com complicações clínicas por malária (MC) (52 P. falciparum e 18 P. vivax), 148 de indivíduos com malária, mas sem complicações clínicas (MNC) (92 P.falciparum, 32 P.vivax, $23 P$. falciparum e $P$. vivax e $1 P$. malariae) e 15 de indivíduos infectados, mas assintomáticos (AS) (9P. falciparum, $1 P$. vivax, $4 P$. falciparum e $P$. vivax e 1 P. malariae).

= 37 amostras de soro de indivíduos com resultado de pesquisa de plasmódio negativo pela gota espessa e $\mathrm{QBC}^{\circledR}$ (18 com sintomas clínicos de malária e 19 sem sintomas).

Foram disponíveis os dados das seguintes variáveis preditoras de exposição à malária:

- Idade ( $\mu=30$ anos $)$

- Número de episódios anteriores de malária $(\mu=11)$, categorizados em: 
$\equiv$ Nenhum episódio de malária anterior $(\mathrm{n}=2)$

$\equiv$ Primo-infectados $(n=30)$

$\equiv$ De 1 a 5 malárias anteriores $(n=86)$

$\equiv$ Mais de 5 malárias anteriores $(n=138)$

$\equiv$ Dados não disponíveis $(\mathrm{n}=16)$

- Tempo de permanência em áreas endêmicas de malária ( $\mu=9$ anos)

- Tempo decorrido desde a última malária ( $M d=1$ mês)

2.3. Amostras de soros de outras patologias $(n=64)$ :

$\equiv$ Soros positivos para Chagas $(\mathrm{n}=9)$

$\equiv$ Soros positivos para Leishmania $(\mathrm{n}=8)$

$\equiv$ Soros positivos para Toxoplasmose $(n=8)$

$\equiv$ Soros positivos para Sífilis $(\mathrm{n}=6)$

$\equiv$ Soros positivos para Proteína C Reativa (PCR) $(n=5)$

$\equiv$ Soros positivos para ASLO $(\mathrm{n}=8)$

$\equiv$ Soros positivos para Fator Reumatóide (FR) $(n=10)$

$\equiv$ Soros de pacientes com Doença Auto-Imune $(n=10)$

2.4. Amostras de soros de doadores de sangue foram obtidas junto à Fundação Pró-sangue/ Hemocentro de São Paulo (n= 89). 


\section{ASPECTOS ÉTICOS DA PESQUISA}

O estudo foi aprovado pela Comissão de Ética para Análise de Projetos de Pesquisa da FMUSP, pela Comissão de Ética da Pesquisa do Instituto de Medicina Tropical de São Paulo (IMT/SP) e pela Comissão de Ética em Pesquisa da Fundação de Medicina Tropical do Amazonas (FMT/IMT-AM).

As amostras biológicas utilizadas pertenciam à soroteca do Laboratório de Soroepidemiologia e Imunobiologia do IMT/SP, originalmente colhidos no contexto de pesquisas afins.

Todos os cuidados necessários em relação aos aspectos éticos da utilização de material biológico estocado foram respeitados, ou seja, foi garantida a preservação rigorosa do anonimato dos indivíduos originariamente envolvidos e o material foi devidamente conservado e utilizado eticamente, bem como as informações obtidas a partir dele.

\section{ANTÍGENOS de $P$. falciparum}

\subsection{Manutenção de $P$. falciparum}

Isolado ADA de $P$. falciparum é mantido no Laboratório de Imunologia e Soroepidemiologia do Instituto de Medicina Tropical de São Paulo, por cultivo in vitro e por congelamento em nitrogênio $\left(\mathrm{N}_{2}\right)$ líquido. 
(a). Congelamento

Eritrócitos de cultivo foram centrifugados e para cada $1 \mathrm{~mL}$ de sedimento foi adicionado $0,34 \mathrm{~mL}$ de "glycerolyte" na velocidade de uma gota/ segundo sob leve agitação. Após 5 minutos de repouso foram adicionados mais $1,36 \mathrm{~mL}$ de "glycerolyte", nas mesmas condições anteriores. O produto final foi aliquotado em $1 \mathrm{~mL}$ em ampola de congelamento, mantido a $-80^{\circ} \mathrm{C}$ por 18 horas e posteriormente, armazenado em "container" contendo $\mathrm{N}_{2}$ líquido. (b). Descongelamento

Os eritrócitos foram descongelados por 2 minutos, em banho-maria a $37^{\circ} \mathrm{C}$, e colocadas em tubo estéril. Foram adicionados sob agitação, $0,2 \mathrm{~mL}$ de $\mathrm{NaCl} 12 \%$, para cada $1 \mathrm{~mL}$ de células congeladas. Após 5 minutos de repouso, foram adicionados $10 \mathrm{~mL}$ de $\mathrm{NaCl} 1,6 \%$ com uma agulha de $21 \mathrm{G}$ (1 a 2 gotas/ segundo). $O$ produto foi centrifugado a $1500 \times \mathrm{g}$ por 10 minutos e o sedimento ressuspenso com $10 \mathrm{~mL}$ de $\mathrm{NaCl}$ 0,9\% e dextrose $0,2 \%$. Após nova centrifugação, o sedimento de eritrócitos foi adicionado ao meio de cultura, para recuperação dos parasitos.

\subsection{Cultivo de $P$. falciparum}

Cultivo de $P$. falciparum foi realizado como descrito por Trager \& Jensen, 1976. Cepas foram cultivadas assincronicamente em eritrócitos humanos tipo "O", Rh positivo na concentração final de $4 \%$, em placas de Petri contendo $8 \mathrm{~mL}$ de meio RPMI 1640 completo em ambiente a $5 \%$ de $\mathrm{CO}_{2}$. A troca do meio de cultura foi feita diariamente, e quando a parasitemia 
alcançar um mínimo de $4 \%$ ou a cada quatro dias, foi feito o repique para duas placas de Petri, contendo meio de cultura.

\subsubsection{Preparo do extrato antigênico somático de $P$. falciparum (PfZw)}

Quando a parasitemia atingiu cerca de 10\%, com formas predominantes de esquizontes, os eritrócitos foram retirados das placas e centrifugados a $1500 \times g$ por 10 minutos. O líquido sobrenadante foi descartado, e o sedimento, lavado por três vezes com solução fisiológica tamponada com fosfatos 0,01M, pH 7.2 (PBS). Após a última centrifugação, o sedimento de eritrócitos foi lisado pela adição de saponina a 0,04\% em PBS, por 20 minutos. Os parasitos liberados foram centrifugados a $3000 \times \mathrm{g}$ por 15 minutos e lavados 3 vezes com PBS. O sedimento obtido foi armazenado a $-80^{\circ} \mathrm{C}$, até o momento do uso.

Antígenos somáticos foram extraídos com detergente anfótero Zwittergent a $10 \%$ em PBS contendo os seguintes inibidores de proteases: aprotinina $(50 \mu \mathrm{g} / \mathrm{mL})$, leupeptina $(1 \mu \mathrm{g} / \mathrm{mL})$ e antipaína $(1 \mu \mathrm{g} / \mathrm{mL})$ e fluoreto de fenilmetilsulfonila (phenylmethyl sulfonyl fluoride - PMSF) 1mM. Para aproximadamente $100 \mathrm{mg}$ (peso úmido) de sedimento de parasitos foram adicionados $200 \mu \mathrm{L}$ de $Z w$ e $1,0 \mathrm{~mL}$ de PBS. O conteúdo protéico do extrato antigênico de $P$. falciparum foi dosado pelo método de Lowry. 


\section{Obtenção de Anticorpos}

5.1. Soro de carneiro anti-lgA, anti-lgG e anti-lgM humanas, fração $F_{a b}$ (específica para fração $F_{c}$ ) foram cedidos gentilmente pela BioMérieux.

5.2. Anticorpos monoclonais anti-lgG1 (clone 8c/6-39), anti-lgG2 (clone HP6014), anti-IgG3 (clone HP6050) e anti-IgG4 (clone HP6025) humanas foram obtidos comercialmente da Sigma Chemical Co.

5.3. Soro de carneiro e de cabra anti-IgE humana foram obtidos comercialmente da Cappel e da Sigma Chem. Co, respectivamente.

5.4. Proteínas de Mieloma purificadas das subclasses $\lg G 1, \lg G 2$, $\lg G 3$ e IgG4 e de IgE foram obtidas comercialmente da Sigma Chem. Co.

\section{Obtenção de Conjugados}

\subsection{Conjugado enzimático proteína - peroxidase}

Os anticorpos anti-lgA, anti-lgG e anti-lgM foram conjugados a peroxidase, segundo metodologia descrita por Wilson \& Nakane, 1978.

Para tanto, peroxidase tipo VI (5mg/mL) foi oxidada com uma solução de $\mathrm{NalO}_{4}$ 0,1M por 30 minutos, à temperatura ambiente. Após diálise contra tampão acetato $0,001 \mathrm{M}, \mathrm{pH} 4,4$ por 24 horas, a $4^{\circ} \mathrm{C}$, foi feita a alcalinização da peroxidase oxidada e do soro a ser conjugado com adição de $50 \mu \mathrm{L}$ de tampão carbonato/ bicarbonato $0,5 \mathrm{M}, \mathrm{pH} 9,5$, em cada solução. Procederse-á a conjugação pela adição lenta da solução protéica a peroxidase e incubação por 2 horas, à temperatura ambiente. Para estabilização do conjugado foi adicionado $\mathrm{NaHB}_{4}$ 0,1M. Após nova incubação por 2 horas, à 
temperatura ambiente e diálise contra PBS por 24 horas, a $4^{\circ} \mathrm{C}$, o conjugado foi diluído $(\mathrm{v} / \mathrm{v})$ em glicerina bidestilada, aliquotado e conservado a $-20^{\circ} \mathrm{C}$, até o momento do uso.

O conjugado anti-IgE humana - peroxidase foi obtido comercialmente da Sigma Chem. Co. e estreptavidina - peroxidase foi obtido comercialmente da Amershan - LIFESCIENCE.

\subsection{Conjugado proteína - biotina}

Anticorpos de anti-IgE humana foram marcados com biotina como descrito por Diamandis \& Cristopoulos, 1991.

Dez microlitros de éster de biotinamidocaproato $\mathrm{N}$-hidroxisuccinamida 0,1M em dimetilformamida (DMF) foram adicionados a $1 \mathrm{~mL}$ da solução de anticorpo de anti-lgE (a $4 \mathrm{mg} / \mathrm{mL}$ em PBS), previamente dialisada contra $\mathrm{NaHCO}_{3} 0,1 \mathrm{M}$ por 24 horas, a $4^{\circ} \mathrm{C}$. A mistura foi mantida à temperatura ambiente por 4 horas, sob leve agitação. Após nova diálise contra PBS por 24 horas, a $4^{\circ} \mathrm{C}$ foi centrifugada a $500 \times g$ por 15 minutos, diluída a 1:2 em glicerina destilada e mantida a $-20^{\circ} \mathrm{C}$ protegida da luz.

Os conjugados anti-lgG1, anti-lgG2, anti-lgG3 e anti-lgG4 humanas marcada com biotina foram obtidos comercialmente da Sigma Chem. Co. A especificidade e os títulos desses conjugados foram determinados por titulação em bloco com os mielomas de cada subclasse de lgG (Anexo I). 


\section{PESQUISA DE SUBCLASSES DE IgG ANTI-FORMAS}

\section{ERITROCITÁRIAS DE P.falciparum}

\subsection{Padronização do ELISA}

Placas NUNC (polysorb) foram sensibilizadas com antígeno de $P$. falciparum a $5 \mu \mathrm{g} / \mathrm{mL}\left(50 \mu \mathrm{L} /\right.$ cavidade) em PBS por 2 horas a $37^{\circ} \mathrm{C}$ e 18 horas a $4^{\circ} \mathrm{C}$. Após, as placas foram lavadas uma vez com PBS contendo 0,05\% de Tween 20 (PBS-Tw) e foram bloqueadas com leite desnatado a $5 \%\left(100 \mu \mathrm{L} /\right.$ cavidade) por 2 horas a $37^{\circ} \mathrm{C}$ e as placas foram novamente lavadas 2 vezes com PBS-Tw e uma vez com água de MilliQ, secas, embrulhadas uma a uma em papel de filtro e armazenadas a $4^{\circ} \mathrm{C}$ em bolsas de alumínio com dessecante até o momento do uso. Para realização da reação imunoenzimática as placas foram mantidas à temperatura ambiente. Foram adicionados $50 \mu \mathrm{L}$ de cada diluição dos 12 soros-padrão controles positivos e negativos para subclasses $\lg G 1, \lg G 2$ e $\lg G 3(1 / 25,1 / 50,1 / 100)$ e para IgG4 $(1 / 5,1 / 10$ e $1 / 20)$ anti $-P$. falciparum em leite desnatado a $2 \%$ em PBS-Tw, nas cavidades das placas, que foram incubadas por 40 minutos a $37^{\circ} \mathrm{C}$. Após 3 lavagens com PBS-Tw, foram adicionados à cada cavidade $50 \mu \mathrm{L}$ das diluições do conjugado específico anti-lgG1 (1/1000), anti-lgG2, anti-lgG3 e anti-lgG4 (1/500), respectivamente e diluídos em leite desnatado a $2 \%$ em PBS-Tw. As placas foram incubadas novamente por 40 minutos a $37^{\circ} \mathrm{C}$ e lavadas 3 vezes com PBS-Tw. Foi adicionado o conjugado estreptavidina-peroxidase $\left(50 \mu \mathrm{L} /\right.$ cavidade), s placas foram incubadas a $37^{\circ}$ C por 40 minutos. Após, foi feito novo ciclo de lavagens de 3 vezes com 
PBS-Tw, foram adicionados à cada cavidade $50 \mu \mathrm{L}$ substrato cromogênico 3,3',5,5'-tetrametilbenzidina $\mathrm{H}_{2} \mathrm{O}_{2}$ (TMB-Sigma Chem. Co) e as placas foram incubadas por 30 minutos a $37^{\circ} \mathrm{C}$. A reação foi interrompida com $25 \mu \mathrm{L}$ de $\mathrm{H}_{2} \mathrm{SO}_{4} 2 \mathrm{~N}$. A densidade óptica (D.O.) do produto colorido obtido foi feita em leitor de microplacas Titertek Multiskan MCC340 a 450 nm.

Após a padronização do ELISA, foram testadas as amostras de soro de área endêmica e dos doadores de sangue. Os resultados foram expressos como índices de reatividade (I.R.), sendo IR= densidade óptica (D.O.) da amostra/ D.O. do "cut-off". O "cut-off" foi calculado pela média das D.O.s de 89 amostras de soro de doadores de sangue mais duas vezes o desvio padrão.

Em cada placa, foram adicionadas diluições dos mielomas de $\lg G 1$, IgG2, IgG3 e IgG4 humanas (5120, 1280, 320,80 20 e $5 \mathrm{ng} / \mathrm{mL}$ ) para a construção de curvas-padrão que foram utilizada no programa ELISA para o cálculo da concentração de subclasses de lgG anti - P. falciparum.

\subsection{Estudo da Afinidade Funcional ou Avidez das Subclasses de IgG anti- P. falciparum}

A técnica ELISA foi realizada conforme descrito acima, sendo que após a incubação das amostras de soros em duplicata, a primeira lavagem de uma duplicata foi feita com solução de uréia $8 \mathrm{M}$ por 5 minutos (100 $\mu \mathrm{L} /$ cavidade). O índice de avidez (I.A.) foi calculado pela relação da D.O. da 
amostra tratada com uréia pela D.O. da amostra sem o tratamento com uréia, multiplicada por 100 .

$$
\text { I.A. }=\frac{\text { D.O. com uréia } \times 100}{\text { D.O. sem uréia }}
$$

\section{PESQUISA DE ANTICORPOS IgE ANTIFORMAS ERITROCITÁRIAS DE P. falciparum}

\subsection{Escolha do conjugado anti-IgE humana}

Foram testados em diferentes ELISAs os seguintes soros anti-IgE humana:

- Soro de carneiro anti-IgE humana $(6 / 7 / 82)(A)$

- Soro de carneiro anti-IgE humana (Cappel) (B)

- Soro de cabra anti-IgE humana marcado com peroxidase Sigma Chem. Co $(11 / 11 / 96)(C)$

- Soro de cabra anti-IgE humana (específica para cadeia $\varepsilon$ ) marcado com peroxidase Sigma Chem. Co (A 9667, lote 029H4887) (D)

- Soro de cabra anti-IgE humana Sigma Chem. Co (55,3 mg/ mL) marcada com biotina $(E)$

Placa NUNC (polysorb) foi sensibilizada com mieloma de IgE humana Sigma Chem. Co $(1,3 \mathrm{mg} / \mathrm{mL})$ a $5 \mu \mathrm{g} / \mathrm{mL}$ em PBS por 2 horas a $37^{\circ} \mathrm{C}$ e 18 horas a $4^{\circ} \mathrm{C}$. A placa foi lavada uma vez com PBS contendo $0,05 \%$ de Tween 20 (PBS-Tw) e foi bloqueada com leite desnatado a 5\%. Após o bloqueio a placa foi lavada 2 vezes com PBS-Tw e uma vez com água de MilliQ. Foram adicionados $100 \mu \mathrm{L}$ dos soros anti-IgE nas diluições $1 / 100$, 
$1 / 500,1 / 1000$ e 1/5000 (soros A a D) e 1/100, 1/200, 1/400 e 1/800 (E) em leite desnatado a $2 \%$ em PBS-Tw e incubados a $37^{\circ} \mathrm{C}$ por 40 minutos. Após novo ciclo de lavagens com PBS-Tw foram adicionados $100 \mu \mathrm{L}$ de anti-lgG de carneiro marcada com peroxidase diluída a 1/1000 em leite desnatado a $2 \%$ em PBS-Tw às cavidades testadas com soros $A$ e $B ; 100 \mu \mathrm{L}$ do substrato cromogênico $\mathrm{TMB} \mathrm{H}_{2} \mathrm{O}_{2}$ (Sigma Chem. Co) às cavidades com soros $C$ e $D$ e $100 \mu \mathrm{L}$ de conjugado estreptavidina - peroxidase diluído a 1/1000 em leite desnatado a $2 \%$ em PBS-Tw às cavidades testadas com soro $\mathrm{E}$, incubados a $37^{\circ} \mathrm{C}$ por 40 minutos (soros $\mathrm{A}, \mathrm{B}$ e $\mathrm{E}$ ) e por 30 minutos (soros C e D). Nas cavidades testando os soros C e D foram adicionados 50 $\mu \mathrm{L}$ de $\mathrm{H}_{2} \mathrm{SO}_{4} 2 \mathrm{~N}$ para interromper a reação enzimática e a leitura das densidades ópticas foram feitas em leitor de microplacas Titertek Multiskan MCC340 a $450 \mathrm{~nm}$. As cavidades correspondentes aos soros A, B e E foram novamente lavadas e incubadas a $37^{\circ} \mathrm{C}$ por 30 minutos com 100 $\mu \mathrm{L} /$ cavidade de substrato cromogênico TMB $\mathrm{H}_{2} \mathrm{O}_{2}$ e posteriormente a reação foi interrompida com $50 \mu \mathrm{L} /$ cavidade de $\mathrm{H}_{2} \mathrm{SO}_{4} 2 \mathrm{~N}$ e foi feita a leitura da densidade óptica como citado acima (Anexo II).

Foram escolhidos dois conjugados para serem testados na posterior padronização do ELISA-lgE: soro de cabra anti-lgE humana marcado com biotina $(E)$ diluído a $1 / 500$ e soro de cabra anti-lgE humana (específica para cadeia $\varepsilon$ ) marcado com peroxidase (D) diluído a 1/1000. 


\subsection{Padronização do ELISA - IgE}

\subsubsection{Absorção dos soros com Rf-absorbent}

Diluições iniciais do soro 1/5, 1/10 e 1/20 em PBS contendo 0,05\% de Tween 20 (PBS-Tw) foram adicionados a volumes iguais de soro de carneiro anti-IgG humana (Rf-absorbent, DadeBehring, Germany), resultando em diluições a 1/10, 1/20 e 1/40, respectivamente.

\subsubsection{ELISA - IgE}

Placas NUNC (polysorb) foram sensibilizadas com antígeno de $P$. falciparum a $5 \mu \mathrm{g} / \mathrm{mL}\left(100 \mu \mathrm{L} /\right.$ cavidade) em PBS por 2 horas a $37^{\circ} \mathrm{C}$ e 18 horas a $4^{\circ} \mathrm{C}$. Após, as placas foram lavadas uma vez com PBS contendo 0,05\% de Tween 20 (PBS-Tw) e foram bloqueadas com leite desnatado a $5 \%\left(100 \mu \mathrm{L} /\right.$ cavidade) por 2 horas a $37^{\circ} \mathrm{C}$ e as placas foram novamente lavadas 2 vezes com PBS-Tw e uma vez com água de MilliQ. Para realização da reação imunoenzimática as placas foram mantidas à temperatura ambiente. Os soros puros e diluídos a 1/2, 1/5, 1/10, 1/20 e 1/40 em leite desnatado a 2\% em PBS-Tw e diluições dos soros a 1/10, 1/20 e 1/40 após absorção com Rf-absorbent foram adicionados em triplicata à placa (100 $\mu \mathrm{L} /$ cavidade) e incubados a $37^{\circ} \mathrm{C}$ por 40 minutos. Após ciclo de 3 lavagens com PBS-Tw foram adicionados em cada uma das triplicatas soro de carneiro anti-lgG humana marcado com peroxidase ou soro de cabra antiIgE humana marcado com peroxidase ou soro de cabra anti-lgE humana marcado com biotina diluídos a 1/10000, 1/1000 e 1/500 em leite desnatado a $2 \%$ em PBS-Tw, respectivamente (100 $\mu \mathrm{L} /$ cavidade). As placas foram 
incubadas a $37^{\circ} \mathrm{Cor} 40$ minutos e foi feito um novo ciclo de 3 lavagens. Foi adicionado o substrato cromogênico TMB $\mathrm{H}_{2} \mathrm{O}_{2}(100 \mu \mathrm{L} /$ cavidade) as replicatas correspondentes aos conjugados com peroxidase e após incubação a $37^{\circ} \mathrm{C}$ por 30 minutos ao abrigo da luz, a reação enzimática foi interrompida com $\mathrm{H}_{2} \mathrm{SO}_{4} 2 \mathrm{~N}$ e a leitura das densidades ópticas foram feitas em leitor de microplacas Titertek Multiskan MCC340 a 450 nm. Foi adicionado o conjugado estreptavidina-peroxidase diluído a 1/1000 em leite desnatado a $2 \%$ em PBS-Tw a replicata correspondente ao conjugado com biotina e incubada a $37^{\circ} \mathrm{C}$ por 40 minutos. Após, foram feitos novo ciclo de lavagens de 3 vezes com PBS-Tw, foram adicionados à cada cavidade 100 $\mu \mathrm{L}$ substrato cromogênico $\mathrm{TMB} \mathrm{H}_{2} \mathrm{O}_{2}$ (Sigma Chem. Co) e as placas foram incubadas por 30 minutos a $37^{\circ} \mathrm{C}$, a reação foi interrompida com $50 \mu \mathrm{L} /$ cavidade de $\mathrm{H}_{2} \mathrm{SO}_{4} 2 \mathrm{~N}$ e foi feita a leitura da densidade óptica como citado acima.

Após a padronização do ELISA, foram testadas as de soro de área endêmica e dos doadores de sangue. Os resultados foram expressos como índices de reatividade (I.R.), sendo I.R.= densidade óptica da amostra (D.O.)/ D.O. do "cut-off". O "cut-off" de cada placa foi calculado a partir da média + duas vezes o desvio padrão das D.O.s de seis soros controles negativos.

Em cada placa, foram adicionadas diluições do mieloma de IgE humana $(5120,1280,320,80,20$ e 5 ng/ mL)para a construção de curvas-padrão que foram utilizadas no programa ELISA para o cálculo da concentração de anticorpos IgE anti- P. falciparum. 


\section{PESQUISA DE ANTICORPOS IgM ANTI-FORMAS ERITROCITÁRIAS}

\section{DE P. falciparum}

\subsection{Otimização do ELISA - IgM Indireto}

Placas NUNC (polysorb) foram sensibilizadas com antígeno de $P$. falciparum a $5 \mu \mathrm{g} / \mathrm{mL}\left(100 \mu \mathrm{L} /\right.$ cavidade) em PBS por 2 horas a $37^{\circ} \mathrm{C}$ e 18 horas a $4^{\circ} \mathrm{C}$. Após, as placas foram lavadas uma vez com PBS contendo 0,05\% de Tween 20 (PBS-Tw) e foram bloqueadas com leite desnatado a $5 \%$, variando o tempo de bloqueio e o modo de estabilização das placas:

- Variáveis A e B: leite desnatado a 5\% em PBS por 2 horas a $37^{\circ} \mathrm{C}(200$ $\mu \mathrm{L} /$ cavidade);

- Variáveis C e D: leite desnatado a $5 \%$ em PBS por 18 horas a $4^{\circ} \mathrm{C}(200$ $\mu \mathrm{L} /$ cavidade);

Variáveis A e C: após o bloqueio, as placas foram lavadas por 2 vezes com PBS contendo Tween 20 a 0,05\% (PBS-Tw) e uma vez com água de MilliQ e tratadas com $150 \mu \mathrm{L} /$ cavidade de solução estabilizadora de proteínas (BioMérieux) por 2 horas, secas, embrulhadas uma a uma em papel de filtro e armazenadas a $4^{\circ} \mathrm{C}$ em bolsas de alumínio com dessecante até o momento do uso.

Variáveis B e D: após o bloqueio, as placas foram lavadas por 2 vezes com PBS contendo Tween 20 a 0,05\% (PBS-Tw) e uma vez com água de MilliQ, secas, embrulhadas uma a uma em papel de filtro e armazenadas a $4^{\circ} \mathrm{C}$ em bolsas de alumínio com dessecante até o momento do uso.

Para realização da reação imunoenzimática as placas foram mantidas à temperatura ambiente. Foram adicionados $100 \mu \mathrm{L}$ de cada diluição dos 12 
soros-padrão controles positivos e negativos em leite desnatado a $2 \%$ em PBS-Tw $(1 / 25,1 / 50,1 / 100,1 / 200)$ nas cavidades das placas, que foram incubadas por 40 minutos a $37^{\circ} \mathrm{C}$. Após 3 lavagens com PBS-Tw, foram adicionados à cada cavidade $100 \mu \mathrm{L}$ das diluições do conjugado específico anti-lgM $(1 / 5000,1 / 10000,1 / 20000,1 / 30000)$ e foi realizada nova incubação por 40 minutos a $37^{\circ} \mathrm{C}$. Após novo ciclo de lavagens de 3 vezes com PBS$\mathrm{Tw}$, foram adicionados à cada cavidade $100 \mu \mathrm{L}$ de substrato cromogênico TMB $\mathrm{H}_{2} \mathrm{O}_{2}$ (Sigma Chem. Co) e as placas foram incubadas por 30 minutos a $37^{\circ} \mathrm{C}$ ao abrigo da luz. A reação foi interrompida com $50 \mu \mathrm{L}$ de $\mathrm{H}_{2} \mathrm{SO}_{4} 2 \mathrm{~N}$. A densidade óptica (D.O.) do produto colorido obtido foi feita em leitor de microplacas Titertek Multiskan MCC340 a $450 \mathrm{~nm}$.

\subsubsection{Determinação da Densidade Óptica Limiar}

A partir dos resultados obtidos com os soros-padrão, estabelecemos melhor diluição dos soros e do conjugado e o melhor bloqueio. Com o ELISA otimizado foram testadas 88 amostras de soro de doadores de sangue para determinação da densidade óptica (D.O.) limiar, que foi calculado pela média das D.O.s dessas 88 amostras mais duas vezes o desvio padrão. 


\subsubsection{Preparação do soro limiar de reatividade}

Foi diluído um "pool" de soros positivos para anticorpos IgM antiformas eritrocitárias em um "pool" de soros negativos a 1/2,1/3, 1/4, 1/8, 1/16,1/32, 1/64 e 1/128. Cada soro artificialmente preparado foi testado no ELISA - IgM indireto otimizado. O soro que fornecer a D.O. mais próxima da D.O. limiar foi escolhido como soro limiar de reatividade (SLR). O SLR foi utilizado em triplicata em todas as placas, com controle de variação intertestes. A média da D.O.s das triplicatas do SLR foi considerada como o corte da reação ("cut-off") de cada placa.

\subsubsection{Aplicação do ELISA - IgM}

Amostras de soro de área endêmica foram testadas em duplicata no ELISA-IgM indireto otimizado. Os resultados de cada amostra foram fornecidos com índice de reatividade (I.R.)m, calculado como a razão entre a média das D.O.s das duplicatas da amostra pela D.O. "cut-off" (D.O. média do SLR).

10. PESQUISA DE ANTICORPOS IgA ANTI -FORMAS ERITROCITÁRIAS DE P. falciparum

\subsection{Otimização do ELISA -IgA}

Placas NUNC (polysorb) foram sensibilizadas com antígeno de $P$. falciparum a $5 \mu \mathrm{g} / \mathrm{mL}(100 \mu \mathrm{L} /$ cavidade $)$ em PBS por 2 horas a $37^{\circ} \mathrm{C}$ e 18 horas a $4^{\circ} \mathrm{C}$. Após, as placas foram lavadas uma vez com PBS contendo 0,05\% de Tween 20 (PBS-Tw) e foram bloqueadas com leite desnatado a 
$5 \%\left(200 \mu \mathrm{L} /\right.$ cavidade) por 2 horas a $37^{\circ} \mathrm{C}$ e as placas foram novamente lavadas 2 vezes com PBS-Tw e uma vez com água de MilliQ, secas, embrulhadas uma a uma em papel de filtro e armazenadas a $4^{\circ} \mathrm{C}$ em bolsas de alumínio com dessecante até o momento do uso. Para realização da reação imunoenzimática a placas foram mantidas à temperatura ambiente.

Foram adicionados $100 \mu \mathrm{L}$ de cada diluição dos 12 soros-padrão controles positivos e negativos em leite desnatado a $2 \%$ em PBS - Tween 0,05\% (PBS-Tw) $(1 / 25,1 / 50,1 / 100$ e 1/200) nas cavidades das placas, que foram incubadas a $37^{\circ} \mathrm{C}$ por 40 minutos. Após 3 lavagens com PBS-Tw, foram adicionados à cada cavidade $100 \mu \mathrm{L}$ das diluições do conjugado específico anti-IgA (1/100, 1/200, 1/400, 1/800, 1/1000 e 1/2000) diluídos em leite desnatado a $2 \%$ em PBS-Tw e foi realizada nova incubação a $37^{\circ} \mathrm{C}$ por 40 minutos. Após novo ciclo de lavagens de 3 vezes com PBS-Tw, foram adicionados à cada cavidade $100 \mu \mathrm{L}$ de substrato cromogênico TMB $\mathrm{H}_{2} \mathrm{O}_{2}$ (Sigma Chem. Co) e as placas foram incubadas por 30 minutos a $37^{\circ} \mathrm{C}$ ao

abrigo da luz. A reação foi interrompida com $50 \mu \mathrm{L}$ de $\mathrm{H}_{2} \mathrm{SO}_{4} 2 \mathrm{~N}$. A densidade óptica (D.O.) do produto colorido obtido foi feita em leitor de microplacas Titertek Multiskan MCC340 a $450 \mathrm{~nm}$.

\subsection{Determinação da densidade óptica limiar}

A partir dos resultados obtidos com os soros-padrão, estabelecemos a melhor diluição dos soros e do conjugado. Com ELISA otimizado foram testadas 88 amostras de soros de doadores de sangue para determinação 
da densidade óptica (D.O.) limiar, que foi calculado pela média das D.O.s dessas 88 amostras mais duas vezes o desvio padrão.

Os resultados de cada amostra foram fornecidos como índice de reatividade (I.R.)m, calculado como a razão entre a média da D.O. das duplicatas da amostra pela D.O. "cut-off".

\section{DETERMINAÇÃO DE IgE e IgA TOTAIS}

\subsection{IgE total}

IgE total foi determinado nos soros por método nefelométrico com partículas de poliestireno com o kit N Látex lgE mono (Dade Behring), no Laboratório Central do Hospital das Clínicas da Faculdade de Medicina da USP (LAC/HC/FMUSP), por Flávia Cristina Kinskowski.

\section{2. $\lg A$ total}

IgA total foi determinada nos soros por método nefelométrico com o kit $\mathrm{N}$ Látex Anti-soros contra imunoglobulinas humanas (Dade Behring), no LAC/HC/FMUSP, por Flávia Cristina Kinskowski. 


\section{DETERMINAÇÃO DO POLIMORFISMO DO GENE DO RECEPTOR} Fc $\gamma R$ IIA $^{131}$

\subsection{Método de Extração de DNA genômico com Fenol/ Clorofórmio}

O DNA de 53 amostras foi extraído segundo protocolo descrito por Snounou et al, 1993 e modificado por Ferreira et al, 1998. Duzentos microlitros de sangue total foram adicionados a $10 \mu \mathrm{L}$ de saponina (Sigma Chem. Co) $1 \%$ e $1 \mathrm{~mL}$ de PBS estéril, e incubados a $37^{\circ} \mathrm{C}$ por 5 minutos, sendo posteriormente centrifugados a $2000 \times g$ por 15 minutos. $O$ sobrenadante foi lavado com $1 \mathrm{~mL}$ de PBS estéril, centrifugado a $2000 \mathrm{xg}$ por 15 minutos. Esta lavagem foi repetida por mais duas vezes. Após a última lavagem, foram adicionados ao sedimento $200 \mu \mathrm{L}$ de solução de lise (Tris-HCl $1 \mathrm{M} \mathrm{pH} \mathrm{8,0,} \mathrm{EDTA} 500 \mathrm{mM} \mathrm{pH} \mathrm{8,0,} \mathrm{NaCl} \mathrm{2,5} \mathrm{M,} \mathrm{SDS} \mathrm{10 \% ,}$ proteinase $\mathrm{K}$ (Sigma Chem Co) $20 \mathrm{mg} / \mathrm{mL}$, qsp $200 \mu \mathrm{L}$ de água estéril). A mistura foi incubada a $56^{\circ} \mathrm{C}$ por 3 horas e em seguida, a proteinase $\mathrm{K}$ foi inativada a $95^{\circ} \mathrm{C}$ por 10 minutos.

Foram adicionados $250 \mu \mathrm{L}$ de fenol equilibrado (Gibco), misturando gentilmente por 10 minutos. Após a centrifugação $10.000 \times g$ por 5 minutos, a fase aquosa foi removida. Posteriormente $250 \mu \mathrm{L}$ de fenol/ clorofórmio (1:1) foram adicionados à amostra, centrifugados a $10.000 \times g$ por 5 minutos, e a fase aquosa foi novamente removida. Este procedimento foi repetido com $250 \mu \mathrm{L}$ de clorofórmio (Merck). Para precipitar o DNA, a fase aquosa foi retirada e colocada em um novo tubo contendo $25 \mu \mathrm{L}$ de acetato de sódio 
$3 \mathrm{M} \mathrm{pH} 5,2$ e $600 \mu \mathrm{L}$ de etanol (Merck) gelado (100\%) e incubada a $-20^{\circ} \mathrm{C}$ "overnight".

Após a incubação, o material foi centrifugado a $14.000 \times g$ por 20 minutos a $4^{\circ} \mathrm{C}$. O sobrenadante foi removido e o sedimento de DNA foi lavado com $600 \mu \mathrm{L}$ de etanol $80 \%$ e novamente centrifugado como descrito acima. O sobrenadante foi descartado e o sedimento foi seco à temperatura ambiente e ressuspenso em $100 \mu \mathrm{L}$ de água estéril.

\subsection{Oligonucleotídeos}

Os oligonucleotídeos para amplificação do PCR foram escolhidos especialmente para amplificar o gene Fc $\gamma$ RIIA -H/ R ${ }^{131}$ e não os genes homólogos Fc $\gamma$ RIIB e Fcy RIIC, como descrito por Jiang et al. (1996) e foram obtidos comercialmente da Invitrogen do Brasil.

SENSE: 5'- GGAAAATCCCAGAAATTCTCGC-3'

ANTISENSE: 5'-CAACAGCCTGACTACCTATTACGCGGG-3'

\subsection{Amplificação por PCR}

A amplificação por PCR foi preparada com 100 ng de DNA genômico, 200 pmol de cada oligonucleotídeo, $200 \mu \mathrm{M}$ dNTP (dATP, dCTP,dTTP, dGTP), $1.7 \cup$ Taq polimerase (Invitrogen), tampão de Taq polimerase contendo $200 \mathrm{mM}$ de Tris- $\mathrm{HCl}\left(\mathrm{pH}\right.$ 8,4), $500 \mathrm{mM}$ de $\mathrm{KCl}, 1,5 \mathrm{mM}$ de $\mathrm{MgCl}_{2}$. O volume foi completado para $100 \mu \mathrm{L}$ com água bidestilada, deionizada e autoclavada. Após uma denaturação inicial a $95^{\circ} \mathrm{C}$ por 5 minutos, 32 ciclos de PCR (denaturação a $94^{\circ} \mathrm{C}$ por 15 segundos, anelamento a $55^{\circ} \mathrm{C}$ por 30 
segundos, extensão a $72^{\circ} \mathrm{C}$ por 40 segundos) e uma extensão final a $72^{\circ} \mathrm{C}$ por 10 minutos foram feitos em aparelho Master Cycler Gradient (Eppendorf). Como controle negativo interno de reação foi utilizado água bidestilada, deionizada e autoclavada.

\subsection{Eletroforese em Gel de Agarose}

Foi utilizada agarose 2\% (Sigma Chem. Co) dissolvida em Tampão de corrida TAE 1x (Tris acetato $40 \mathrm{mM}$, EDTA $2 \mathrm{mM}$ ) e solubilizada por aquecimento. As amostras foram analisadas para verificar se ocorreu amplificação do produto de 366 pares de base (bp). A todas as amostras foi adicionado tampão de amostra de DNA (0,5\% de azul de bromofenol, 100 mM EDTA e 50\% de glicerol). Após a corrida, o gel foi corado com brometo de etídio $(0,5 \mu \mathrm{g} / \mathrm{mL})$ durante 40 minutos ao abrigo da luz. $\mathrm{O}$ padrão de bandas foi analisado em transluminador sob fonte de luz UV e o gel foi fotografado em aparelho Stratagene Eagle Eye ${ }^{R}$.

\subsection{Digestão do produto de PCR com enzima de restrição}

Para digestão do produto de PCR foi realizada uma mistura contendo $10 \mu \mathrm{L}$ do produto de PCR (366 pares de base (bp)), 0,5U/ $\mu \mathrm{L}$ Bsh1236I (FnuDII) (Fermentas), 0,5 $\mu \mathrm{L}$ de tampão $\mathrm{R}^{+}$contendo $10 \mathrm{mM}$ Tris- $\mathrm{HCl}(\mathrm{pH}$ 8,5), $10 \mathrm{mM} \mathrm{MgCl}, 100 \mathrm{mM} \mathrm{KCl}$ e $0,1 \mathrm{ng} / \mathrm{mL}$ BSA (Fermentas). O volume foi completado para $20 \mu \mathrm{L}$ com água bidestilada, deionizada e autoclavada. A mistura foi incubada a $37^{\circ} \mathrm{C}$ por 4 horas e após a incubação a enzima de restrição foi inativada a $65^{\circ} \mathrm{C}$ por 20 minutos. Após a digestão com Bsh1236I 
(FnuDII), produz um fragmento de 343 pares de base (bp) $\left(H / H^{131}\right)$ ou um fragmento de 322 pares de base (bp) $\left(R / R^{131}\right)$ ou um fragmento de cada 343bp e 322bp, respectivamente $\left(H / R^{131}\right)$.

\subsection{Eletroforese em Gel de Agarose}

Foi utilizada agarose 3\% (Sigma Chem. Co) dissolvida em Tampão de corrida TAE 1x (Tris acetato $40 \mathrm{mM}$, EDTA $2 \mathrm{mM}$ ) e solubilizada por aquecimento. O padrão de peso molecular utilizado foi o 100bp DNA Ladder (Gibco). A todas as amostras foi adicionado tampão de amostra de DNA (0,5\% de azul de bromofenol, 100 mM EDTA e 50\% de glicerol). Após a corrida, o gel foi corado com brometo de etídio $(0,5 \mu \mathrm{g} / \mathrm{mL})$ durante 40 minutos ao abrigo da luz. O padrão de bandas foi analisado em transluminador sob fonte de luz UV e o gel foi fotografado em aparelho Stratagene Eagle Eye ${ }^{R}$.

\section{Análise Estatística}

Todas as análises estatísticas e dos dados descritivos foram realizados no Programa Sigma Stat (Jandel Scientific) e Prysma. Os resultados dos índices de reatividade e da concentração de anticorpos foram apresentados em medianas. As comparações entre dois grupos para amostras independentes foram feitas pelo teste paramétrico não paramétrico MannWhitney. As comparações entre grupos múltiplos para amostras independentes foram feitas pelo teste não paramétrico Kruskal Wallis. As comparações entre as freqüências e proporções foram feitas pelo teste do 
Qui-quadrado $\left(\chi^{2}\right)$ e teste de Fischer (para pequenas casuísticas). Todas as probabilidades dos testes foram feitas para um nível de significância de 95\%.

Os resultados em concentração das imunoglobulinas $\lg G 1$, IgG2, IgG3, IgG4 e IgE foram determinados a partir de curvas-padrão dos respectivos mielomas usando-se o programa ELISA desenvolvido por Plikyatis et al, 1995 (Centers for Disease Control and Prevention, Atlanta, GA, USA). O programa usa uma função log - logística de quatro parâmetros para descrever dados de padrões e formar as curvas de calibração. 
V. RESULTADOS 


\section{PADRONIZAÇÃO DOS TESTES IMUNOENZIMÁTICOS PARA A PESQUISA DE DIFERENTES CLASSES E SUBCLASSES DE IMUNOGLOBULINAS ANTI-Plasmodium falciparum}

\subsection{Subclasses de IgG}

Na tabela 1 mostramos os resultados da padronização do ELISA para pesquisa de subclasses de anticorpos IgG anti-P. falciparum usando 12 soros positivos e 12 soros negativos para IgG anti- $P$. falciparum.

Pelos resultados apresentados na tabela 1, escolhemos a diluição dos soros a 1/50 para pesquisa de anticorpos $\lg G 1$, $\lg G 2$ e $\lg G 3$ anti- $P$. falciparum. A pesquisa de anticorpos lgG4 foi avaliada com diluições dos soros a $1 / 5,1 / 10$ e $1 / 20$, sendo que os melhores resultados foram obtidos com a diluição a 1/5. A diluição do conjugado anti-lgG1 a 1/1000 e para as demais subclasses a diluição a 1/500, estabelecidas a partir da titulação dos conjugados com mielomas das respectivas subclasses de lgG (Anexo I).

Foram testadas 89 amostras de soro de doadores de sangue, sendo que a média mais duas vezes o desvio padrão das D.O.s obtidas com essas amostras foram 0,077 para IgG1, 0,108 para IgG2, 0,023 para IgG3 e 0,029 para IgG4. Calculamos o IR de cada soro negativo, e a partir desses calculamos o IR limiar que foi de 1,0 para todas as subclasses. Assim, todas as amostras com IR $\geq 1,0$ foram consideradas positivas. 
Tabela 1. Resultados da padronização do ELISA para pesquisa de anticorpos IgG1, IgG2, IgG3 e IgG4 anti-P. falciparum em 12 amostras de soros positivos e 12 negativos para anticorpos IgG anti-P. falciparum.

\begin{tabular}{|c|c|c|c|c|c|c|c|c|c|c|}
\hline \multirow{3}{*}{$\begin{array}{l}\text { Subclasses } \\
\text { de } \\
\text { anticorpos }\end{array}$} & \multirow{3}{*}{ Soros } & \multicolumn{9}{|c|}{ Resultados do ELISA (D.O.) } \\
\hline & & \multicolumn{3}{|c|}{$1 / 25$} & \multicolumn{3}{|c|}{$1 / 50$} & \multicolumn{3}{|c|}{$1 / 100$} \\
\hline & & Méd & máx & mín & Méd & Max & mín & Méd & máx & mín \\
\hline \multirow[t]{2}{*}{$\lg G 1$} & Pos & 2,099 & 2,514 & 1,750 & 1,987 & 2,370 & 1,580 & 1,830 & 2,444 & 1,010 \\
\hline & Neg & 0,081 & 0,252 & 0,010 & 0,035 & 0,107 & 0,000 & 0,010 & 0,070 & 0,000 \\
\hline \multirow[t]{2}{*}{$\lg G 2$} & Pos & 0,605 & 1,222 & 0,130 & 0,480 & 0,964 & 0,060 & 0,373 & 0,771 & 0,030 \\
\hline & Neg & 0,029 & 0,069 & 0,010 & 0,017 & 0,044 & 0,000 & 0,008 & 0,022 & 0,000 \\
\hline \multirow[t]{4}{*}{$\lg G 3$} & Pos & 0,334 & 1,059 & 0,060 & 0,253 & 0,794 & 0,030 & 0,193 & 0,573 & 0,020 \\
\hline & Neg & 0,003 & 0,007 & 0,000 & 0,003 & 0,007 & 0,000 & 0,002 & 0,005 & 0,000 \\
\hline & & & $1 / 5$ & & & $1 / 10$ & & & $1 / 20$ & \\
\hline & & Méd & máx & mín & Méd & Max & mín & Méd & máx & mín \\
\hline \multirow[t]{2}{*}{$\lg G 4$} & Pos & 0,089 & 0,989 & 0,000 & 0,077 & 0,871 & 0,000 & 0,067 & 0,756 & 0,000 \\
\hline & Neg & 0,004 & 0,014 & 0,000 & 0,002 & 0,004 & 0,000 & 0,001 & 0,001 & 0,000 \\
\hline
\end{tabular}

\subsection{Anticorpos IgE}

Na tabela 2 apresentamos os resultados da padronização do ELISA para pesquisa de anticorpos IgE anti-P. falciparum com dois soros controles positivos e três soros de doadores de sangue de área não endêmica e testando dois conjugados anti-IgE humana e o conjugado anti-IgG humana. 
Tabela 2. Resultados do ELISA para pesquisa de anticorpos IgE específicos com conjugados anti-IgG humana peroxidase ( $\alpha$-lgG-Po), anti-lgE humana marcado com peroxidase ( $\alpha-\lg E-P o)$, anti-lgE humana marcada com biotina ( $\alpha-\lg E-B) . R F=$ pré-absorção dos anticorpos lgG com RF-absorbent.

\begin{tabular}{|c|c|c|c|c|c|c|c|c|}
\hline \multirow[b]{2}{*}{ Soro } & \multirow[b]{2}{*}{ Conjugado } & \multicolumn{7}{|c|}{ Diluições do soro } \\
\hline & & & puro & $1 / 2$ & $1 / 5$ & $1 / 10$ & $1 / 20$ & $1 / 40$ \\
\hline \multirow{6}{*}{ P8 } & $\alpha-\lg G-P o$ & & 0,125 & 0,341 & $-0,021$ & 0,492 & 0,588 & 0,24 \\
\hline & & $\mathrm{RF}$ & - & - & - & 0,315 & 0,333 & 0,425 \\
\hline & $\alpha-\lg E-P o$ & & 0,034 & 0,182 & $-0,006$ & 0,019 & 0,002 & 0,042 \\
\hline & & $\mathrm{RF}$ & - & - & & 0,059 & 0,058 & 0,198 \\
\hline & $\alpha-\lg E-B$ & & 0,022 & 0,038 & 0,017 & 0,002 & $-0,01$ & $-0,021$ \\
\hline & & $\mathrm{RF}$ & - & - & - & 0,058 & 0,14 & 0,119 \\
\hline \multirow{6}{*}{ P29 } & $\alpha-\lg G-P o$ & & $-0,086$ & 0,303 & 0,417 & 0,361 & 0,393 & 0,261 \\
\hline & & RF & - & - & - & 0,368 & 0,348 & 0,426 \\
\hline & $\alpha-\lg E-P o$ & & $-0,01$ & $-0,002$ & $-0,008$ & $-0,028$ & 0,005 & $-0,011$ \\
\hline & & $\mathrm{RF}$ & - & - & - & 0,013 & 0,097 & 0,095 \\
\hline & $\alpha-\lg E-B$ & & 0,049 & 0,041 & 0,005 & $-0,008$ & $-0,023$ & $-0,028$ \\
\hline & & RF & - & - & - & 0,071 & 0,157 & 0,235 \\
\hline \multirow{3}{*}{$\mathrm{N} 1$} & $\alpha-\lg G-P o$ & & 0,051 & $-0,111$ & $-0,102$ & $-0,148$ & $-0,119$ & $-0,117$ \\
\hline & $\alpha-\lg E-P o$ & & $-0,067$ & $-0,042$ & $-0,072$ & $-0,086$ & $-0,075$ & $-0,053$ \\
\hline & $\alpha-\lg G-P o$ & & 0,009 & $-0,064$ & $-0,097$ & $-0,113$ & $-0,097$ & $-0,094$ \\
\hline \multirow[t]{2}{*}{ N2 } & $\alpha-\lg E-P o$ & & $-0,072$ & $-0,039$ & $-0,044$ & $-0,08$ & $-0,093$ & $-0,094$ \\
\hline & $\alpha-\lg G-P o$ & & $-0,006$ & $-0,095$ & $-0,087$ & $-0,106$ & $-0,108$ & $-0,097$ \\
\hline N3 & $\alpha-\lg E-P o$ & & $-0,082$ & $-0,068$ & $-0,078$ & $-0,088$ & $-0,057$ & $-0,082$ \\
\hline
\end{tabular}

Baseados nos resultados acima, escolhemos o conjugado anti-lgE humana marcada com biotina e a diluição dos soros a 1/40 após tratamento 
com RF-Absorbent para a execução do ELISA para pesquisa de anticorpos IgE anti-P. falciparum.

Assim padronizada, foram testadas 84 amostras de soros de doadores de sangue de área não endêmica e calculados os IRs de cada um. A média mais duas vezes o desvio padrão dos IRs dos controles negativos foi considerado como o IR limiar, que foi 1,00. Assim, todas as amostras com IR $\geq 1,0$ foram consideradas positivas.

\subsection{Anticorpos $\lg M$}

Foi feita a otimização do ELISA-IgM indireto, testando-se 4 diluições dos 12 soros controles positivos e negativos $(1 / 25,1 / 50,1 / 100$ e 1/200) e 4 diluições do conjugado anti-lgM humana $(1 / 5.000,1 / 10.000,1 / 20.000$ e 1/30.000), com quatro variáveis do tempo de bloqueio e armazenamento das placas após o bloqueio (Anexo III).

As condições escolhidas foram: bloqueio por 2 horas a $37^{\circ} \mathrm{C}$, com secagem direta das placas para o posterior armazenamento (variável B), diluição a 1/100 dos soros e diluição a 1/20.000 do conjugado para a continuação dos experimentos. Definidas essas variáveis, foram testadas 88 amostras de soro de doadores de sangue, para a determinação da D.O. limiar ("cut-off"). A média das D.O.s desses soros foi 0.123 , com um desvio padrão (DP) de 0.096, assim, o cálculo da D.O. limiar ("cut-off") foi:

\footnotetext{
"cut-off"= média das D.Os. $+2 \times$ DP= 0,123 + 2 × 0,096=0,315
} 
Considerando esse "cut-off", 3 amostras de soro de doadores de sangue foram positivas ( $\mathrm{DO}>0,315$ ), portanto, a especificidade foi de $97 \%$.

Para a preparação do soro limiar de reatividade, foi diluído um "pool" de soros positivos para anticorpos IgM anti-formas eritrocitárias em um "pool" de soros negativos a 1/2,1/3,1/4,1/8,1/16,1/32, 1/64 e 1/128. Cada soro artificialmente preparado foi testado no ELISA-IgM indireto otimizado. O soro que forneceu a D.O. mais próxima a D.O.limiar foi escolhido como soro limiar de reatividade (SLR), que foi o "pool" de soros positivos diluídos a $1 / 3 \mathrm{em}$ "pool" de soros negativos (Anexo III).

\subsection{Anticorpos $\lg A$}

\subsubsection{ELISA-IgA indireto}

A padronização do ELISA indireto para pesquisa de anticorpos IgA antiformas eritrocitárias de P.falciparum foram testadas 4 diluições de 6 soros controles positivos e 6 negativos (1/25, 1/50, 1/100 e 1/200) e 6 diluições do conjugado anti-lgA humana (1/100,1/200, 1/400, 1/800,1/1000 e 1/2000).

Foram escolhidas as diluições 1/25 dos soros e 1/2000 do conjugado para continuação dos experimentos. Foram testadas 88 amostras de doadores de sangue, sendo que a média mais duas vezes o desvio padrão das D.O.s obtidas com essas amostras foi 0.432 . Calculamos o IR de cada soro negativo, e a partir desses calculamos o IR limiar que foi de 1,0. Assim, todas as amostras com IR $\geq 1,0$ foram consideradas positivas. 


\subsection{Outras patologias testadas nos ELISAs}

Foram testadas amostras de soro de outras patologias nos ELISAs para pesquisa dos anticorpos $\lg G$ e $\lg M$ e das subclasses de $\lg G$ e os resultados obtidos são apresentados na tabela 3. Uma amostra de indivíduo com FAN reagente foi positivo para anticorpos IgM ; uma amostra de indivíduo com Doença de Chagas, PCR e FAN e duas amostras de indivíduo com Leishmaniose Cutânea foram positivas para IgG; uma amostra de indivíduo com Doença de Chagas, Toxoplasmose, PCR, ASLO e FAN foi positiva para IgG1; uma amostra de indivíduo com Leishmaniose Cutânea, Sífilis, PCR, ASLO e FAN foi positiva para IgG2; uma amostra de indivíduo com Leishmaniose Cutânea, Toxoplasmose, PCR, ASLO e FR foi positiva para lgG3 e uma amostra de indivíduo com Toxoplasmose foi positiva para IgG4. No entanto, estas amostras apresentaram sempre índices de reatividade baixos, muito próximo do limiar considerado.

Tabela 3. Freqüências de amostras de soro de indivíduos com outras patologias positivas nos ELISA para pesquisa de diferentes classes e subclasses de anticorpos anti-formas eritrocitárias de $P$. falciparum.

\begin{tabular}{lcccccc}
\hline \multirow{2}{*}{ Outras patologias } & \multicolumn{5}{c}{ ELISA (\% de amostras de soro positivas) } \\
\cline { 2 - 7 } & lgM & $\operatorname{lgG}$ & $\operatorname{lgG} 1$ & $\operatorname{lgG} 2$ & $\operatorname{lgG} 3$ & $\operatorname{lgG} 4$ \\
\hline Chagas $(\mathrm{n}=9)$ & 0,0 & 11,1 & 11,1 & 0,0 & 0,0 & 0,0 \\
Leishmaniose $(\mathrm{n}=8)$ & 0,0 & 25,0 & 25,0 & 12,5 & 12,5 & 0,0 \\
Toxoplasmose $(\mathrm{n}=8)$ & 0,0 & 0,0 & 12,5 & 0,0 & 12,5 & 12,5 \\
Sífilis $(\mathrm{n}=6)$ & 0,0 & 0,0 & 16,7 & 16,7 & 0,0 & 0,0 \\
PCR $(\mathrm{n}=5)$ & 0,0 & 20,0 & 20,0 & 20,0 & 20,0 & 0,0 \\
ASLO $(\mathrm{n}=8)$ & 0,0 & 0 & 12,5 & 12,5 & 12,5 & 0,0 \\
FR $(\mathrm{n}=10)$ & 0,0 & 0,0 & 10,0 & 0,0 & 10,0 & 0,0 \\
FAN $(\mathrm{n}=10)$ & 10,0 & 10,0 & 10,0 & 10,0 & 0,0 & 0,0 \\
\hline \hline
\end{tabular}




\section{QUANTIDADE E QUALIDADE DOS ANTICORPOS}

A quantidade das diferentes classes e subclasses de anticorpos antiPlasmodium falciparum produzidas durante a resposta imune ao plasmódio foi expressa em (a). Níveis de anticorpos, calculados em índices de reatividade (IR) ou em concentração $(\mu \mathrm{g} / \mathrm{mL})$ e em (b). Freqüência de amostras de soros positivos. A quantidade foi analisada no total das amostras e considerando-se a presença de infecção por plasmódio detectada por métodos parasitológicos, gota espessa e $\mathrm{QBC}^{\circledR}$.

A qualidade dos anticorpos foi avaliada (a). Pela determinação do índice de avidez dos anticorpos; (b). Pelas diferenças no padrão de resposta humoral entre os indivíduos com complicações clínicas causadas pela malária, os infectados sem nenhuma complicação clínica e os infectados assintomáticos; (c). Pelas correlações com variáveis preditoras de exposição prévia à malária. 


\subsection{Anticorpos IgG e subclasses de IgG}

Na tabela 4 apresentamos os níveis dos anticorpos lgG (em índice de reatividade (IR)) e das subclasses lgG1, IgG2, IgG3 e IgG4 (em IR e concentração $\mu \mathrm{g} / \mathrm{mL}$ ) anti-formas eritrocitárias de P.falciparum no total de 270 indivíduos de área endêmica e considerando a presença ou não de infecção por plasmódio. Observamos que maiores níveis de $\lg G$ (em IR), $\lg G 1, \lg G 2$ e $\lg G 3$ (em concentração) ocorreram significantemente nos indivíduos não infectados em relação aos infectados, e o inverso foi observado para lgG4, cujos maiores níveis foram encontrados entre os indivíduos infectados do que nos não infectados. Quanto ao índice de avidez, maiores índices de avidez de lgG foram observados nos indivíduos não infectados significantemente e para as subclasses, as diferenças na foram significantes.

Considerando os seguintes níveis normais das subclasses de lgG no soro: IgG1, 9mg/mL, IgG2 3mg/mL, IgG3 1mg/mL e lgG4 0,5mg/mL (ABBAS et al, 2000), as concentrações medianas das subclasses específicas para formas eritrocitárias de P.falciparum encontradas na população estudada representaram $16,4 \%, 11,7 \%, 11,4 \%$ e $0,2 \%$ das IgG1, IgG2, IgG3 e IgG4 totais, respectivamente.

As freqüências de amostras de soros positivos para anticorpos lgG e das subclasses IgG1, IgG2, IgG3 e IgG4 no total das 270 amostras de soro de indivíduos de área endêmica e considerando a presença ou não de infecção por plasmódios são apresentadas na tabela 5. Não houve diferença significante das freqüências de positivos entre os indivíduos infectados e não 
infectados $(P>0,05)$. Quando consideramos a espécie de Plasmodium infectante, foi observada diferença significante das freqüências de positivos para os anticorpos IgG1 entre os indivíduos infectados por $P$. falciparum $(78,43 \%)$ e os infectados por $P$. vivax $(62,7 \%)\left(\chi^{2}=4,16 ; P=0,04\right)$, e também houve uma diferença significante entre os indivíduos infectados por $P$. vivax $(62,7 \%)$ e os infectados com malária mista $(92,6 \%)\left(\chi^{2}=6,55 ; P=0,01\right)$, mas não para os anticorpos $\lg G$ e as demais subclasses $(P>0,05)$.

$\mathrm{Na}$ figura 4 apresentamos as freqüências dos anticorpos $\lg \mathrm{G}$ e das subclasses de IgG de baixa avidez e de alta avidez no total de amostras estudadas e agrupadas entre os indivíduos infectados e os não infectados.

No total de indivíduos predominam anticorpos $\lg G$, $\lg G 1$ e $\lg G 2$ de alta avidez, enquanto anticorpos lgG3 e lgG4 predominam os de baixa avidez. Entre os indivíduos infectados por plasmódio, predominaram anticorpos lgG, IgG1, IgG2 e IgG3 de baixa avidez e anticorpos IgG4 de alta avidez; o oposto sendo observado entre os indivíduos não infectados, em que predominaram anticorpos $\lg G$, lgG1, lgG2 e lgG3 de alta avidez e anticorpos IgG4 de baixa avidez, apesar de existir diferença significante apenas para os anticorpos $\lg G\left(\chi^{2}=4,34 ; P=0,037\right)$. 
Tabela 4. Resultados das medianas dos níveis e da avidez dos anticorpos $\lg G$, IgG1, $\lg G 2$, IgG3 e $\lg G 4$ anti-formas eritrocitárias de $P$. falciparum obtidos no ELISA com 270 amostras de soro de indivíduos de área endêmica de malária. IR= índice de reatividade (DO da amostra/ DO do "cutoff"); $[\mathrm{Ig}]=$ concentração da subclasse em $\mu \mathrm{g} / \mathrm{mL} ; \mathrm{IA}=$ índice de avidez (DO da amostra tratada com uréia/DO amostra tratada com PBS) $\times 100 ; \quad P=$ probabilidade a $95 \%$ de existir diferença entre os grupos (teste de MannWhitney). Em vermelho estão os resultados com diferença significante.

\begin{tabular}{|c|c|c|c|c|c|c|c|}
\hline \multirow[b]{2}{*}{ Anticorpo } & \multirow[b]{2}{*}{ População } & \multicolumn{4}{|c|}{ Níveis de anticorpos } & \multicolumn{2}{|c|}{ IA } \\
\hline & & $\begin{array}{c}{[\mathrm{lg}]} \\
(\mu \mathrm{g} / \mathrm{mL})\end{array}$ & $P$ & IR & $P$ & $\%$ & $P$ \\
\hline \multirow[t]{3}{*}{$\overline{l g G}$} & total & 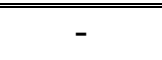 & 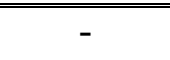 & $\overline{3,01}$ & & 62,0 & \\
\hline & infectados & - & - & 2,97 & 0,0395 & 60,3 & 0,0426 \\
\hline & não infectados & - & - & 3,83 & & 68,6 & \\
\hline \multirow[t]{3}{*}{$\operatorname{lgG1}$} & total & 14,8 & & 6,72 & & 64,0 & \\
\hline & infectados & 13,0 & 0,0115 & 5,99 & 0,0425 & 62,1 & 0,0652 \\
\hline & não infectados & 28,4 & & 11,06 & & 76,4 & \\
\hline \multirow[t]{3}{*}{$\lg G 2$} & total & 3,50 & & 0,59 & & 60,6 & \\
\hline & infectados & 3,35 & $<0,0001$ & 0,55 & 0,0076 & 58,5 & 0,2999 \\
\hline & não infectados & 7,55 & & 1,43 & & 67,0 & \\
\hline \multirow[t]{3}{*}{$\operatorname{lgG} 3$} & total & 1,14 & & 1,43 & & 43,6 & \\
\hline & infectados & 1,09 & 0,0061 & 1,35 & 0,079 & 42,9 & 0,6886 \\
\hline & não infectados & 2,97 & & 1,65 & & 52,6 & \\
\hline \multirow[t]{3}{*}{ IgG4 } & total & 0,01 & & 0,2 & & 444,8 & \\
\hline & infectados & 0,02 & 0,0261 & 0,225 & 0,0393 & 48,9 & 0,6031 \\
\hline & não infectados & 0,01 & & 0,15 & & 38,7 & \\
\hline
\end{tabular}


Tabela 5. Resultados das freqüências de amostras de soros positivas no ELISA para anticorpos IgG e subclasses $\lg G 1$, IgG2, IgG3 e $\lg G 4$ antiformas eritrocitárias de $P$. falciparum no total de 270 indivíduos residentes em áreas endêmicas de malária e agrupadas pelos resultados da pesquisa de plasmódios pela gota espessa e QBC ${ }^{\circledR}$.

\begin{tabular}{|c|c|c|c|c|c|c|c|c|c|}
\hline \multirow{2}{*}{\multicolumn{3}{|c|}{ ANTICORPOS }} & \multicolumn{4}{|c|}{ RESULTADOS DA PARASITEMIA } & \multirow{2}{*}{$\mathrm{Pm}$} & \multirow{2}{*}{ Neg } & \multirow{2}{*}{ Tota } \\
\hline & & & $\begin{array}{c}\text { Plasmodium } \\
+\end{array}$ & $\mathrm{Pt+}$ & & & & & \\
\hline & & & 233 & 153 & 27 & 51 & 2 & 37 & 270 \\
\hline \multirow[t]{3}{*}{$\lg G$} & Pos & $\mathrm{N}$ & 178 & 115 & 23 & 38 & 2 & 31 & 209 \\
\hline & & $\%$ & 76,4 & 75,2 & 85,2 & 74,5 & 100 & 83,8 & 77,4 \\
\hline & & & 233 & 153 & 27 & 51 & 2 & 37 & 270 \\
\hline \multirow[t]{3}{*}{$\lg \mathrm{lg} 1$} & Pos & $\mathrm{N}$ & 179 & 120 & 25 & 32 & 2 & 33 & 212 \\
\hline & & $\%$ & 76,8 & 78,4 & 92,6 & 62,7 & 100 & 89,2 & 78,5 \\
\hline & & & 233 & 153 & 27 & 51 & 2 & 37 & 270 \\
\hline \multirow[t]{3}{*}{$\operatorname{lgG} 2$} & Pos & $\mathrm{N}$ & 96 & 66 & 12 & 16 & 2 & 22 & 118 \\
\hline & & $\%$ & 41,2 & 43,1 & 44,4 & 31,4 & 100 & 59,5 & 43,7 \\
\hline & & & 233 & $\begin{array}{l}153 \\
\end{array}$ & 27 & 51 & 2 & 37 & 270 \\
\hline \multirow[t]{3}{*}{$\lg G 3$} & Pos & $\mathrm{N}$ & 133 & 91 & 14 & 27 & 1 & 24 & 157 \\
\hline & & $\%$ & 57,1 & 59,5 & 51,9 & 52,9 & 50 & 64,9 & 58,1 \\
\hline & Total & & 198 & (130 & 19 & 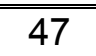 & 2 & 35 & 233 \\
\hline \multirow[t]{2}{*}{$\operatorname{lgG} 4$} & Pos & $\mathrm{N}$ & 32 & 21 & 3 & 8 & - & 3 & 35 \\
\hline & & $\%$ & 16,2 & 16,2 & 15,8 & 17,0 & - & 8,6 & 15,0 \\
\hline
\end{tabular}


$\lg G 1$

(\%)

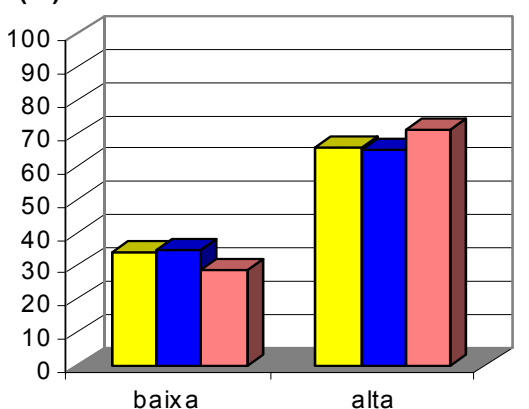

$\lg G 3$

(\%)

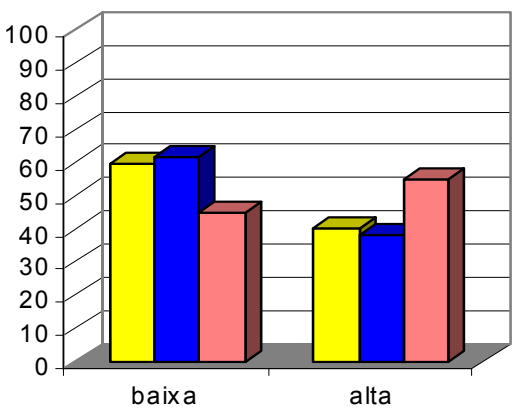

IgG2

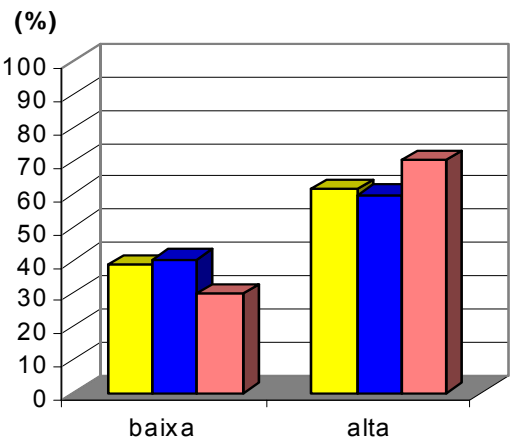

$\lg G 4$

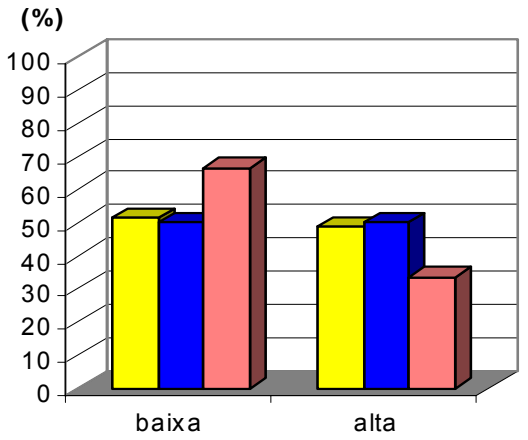

$\lg G$

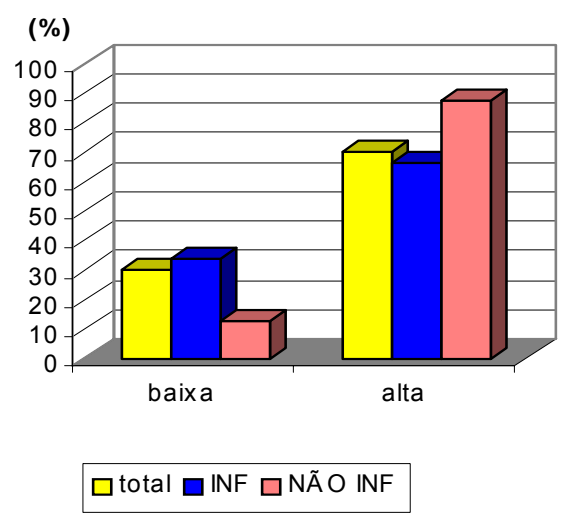

Fig. 4. Freqüências dos anticorpos $\lg G$ e das subclasses $\lg G 1$, IgG2, IgG3 e IgG4 anti-formas eritrocitárias de $P$. falciparum de baixa avidez e de alta avidez no total de indivíduos $(n=270)$ de área endêmica de malária e agrupados entre os indivíduos infectados por plasmódios (INF) (n=233) e os não infectados (NÃO INF) $(n=37)$ testados no ELISA. 
Correlacionamos os índices de reatividade de lgG, as concentrações das subclasses e os níveis de avidez dos anticorpos IgG e das subclasses com as variáveis preditoras de exposição à malária, como idade, número de malárias anteriores e tempo de permanência na área endêmica. Correlações positivas e significantes entre a idade e os níveis de IR-IgG, IgG1, IgG2, IAIgG, IA-lgG1 e IA-lgG4 (resultados significantes das correlações de Spearman na tabela 6). O tempo de permanência não apresentou nenhuma correlação significante com os resultados de anticorpos $(P>0,05)$.

Correlações positivas e significantes foram obtidas no teste de correlação de Spearman entre número de malárias anteriores e níveis de lgG, $\lg G 1, \lg G 2$ e $\lg G 3$ (tabela 6).

No gráfico da figura 5 apresentamos as freqüências dos anticorpos $\lg \mathrm{e}$ subclasses IgG1, IgG2, IgG3 e IgG4 para anticorpos anti-P. falciparum considerando o número de malárias anteriores relatadas pelos indivíduos estratificados em: mais de cinco malárias anteriores $(>5)(n=138)$, de uma a cinco malárias anteriores (1 a 5) $(n=86)$ e primo-infectados (primo) $(n=30)$.

As freqüências de amostras positivas para anticorpos $\lg G 1$ diferiram significantemente entre os grupos com mais de 5 malárias anteriores, de 1 a 5 e primo-infectados, $94,2 \%, 69,8 \%$ e $36,7 \%$, respectivamente $\left(\chi^{2}=56,3 \%\right.$, $P<0,0001)$, apesar de não terem diferido se os indivíduos estavam ou não infectados $(P>0,05)$. 
Tabela 6. Resultados dos coeficientes de correlação de Spearman e das probabilidades que foram significantes a $95 \%$ quando correlacionados variáveis preditoras de exposição à malária (idade, número de episódios anteriores de malária) e os níveis de anticorpos lgG e subclasses lgG1, lgG2, lgG3 e lgG4 anti-formas eritrocitárias e os respectivos níveis de avidez no ELISA.

\begin{tabular}{|c|c|c|c|}
\hline \multicolumn{2}{|c|}{ Correlação (Spearman) } & \multirow{2}{*}{$\begin{array}{c}\mathbf{r} \\
0,13\end{array}$} & \multirow{2}{*}{$\begin{array}{c}\boldsymbol{P} \\
0,033\end{array}$} \\
\hline & IR-IgG & & \\
\hline & IA-IgG & 0,19 & 0,009 \\
\hline & $\operatorname{lgG} 1$ & 0,17 & 0,008 \\
\hline \multirow[t]{5}{*}{ Idade } & IA-IgG1 & 0,15 & 0,031 \\
\hline & $\lg G 2$ & 0,16 & 0,008 \\
\hline & IA-lgG4 & 0,35 & 0,041 \\
\hline & IR-IgG & 0,30 & 0,000 \\
\hline & IA-IgG & 0,16 & 0,028 \\
\hline Número de & $\lg G 1$ & 0,51 & 0,000 \\
\hline Malárias & IA-lgG1 & 0,30 & 0,000 \\
\hline \multirow[t]{3}{*}{ anteriores } & $\lg G 2$ & 0,45 & 0,000 \\
\hline & $\lg G 3$ & 0,33 & 0,000 \\
\hline & $\lg G 4$ & $-0,23$ & 0,000 \\
\hline
\end{tabular}



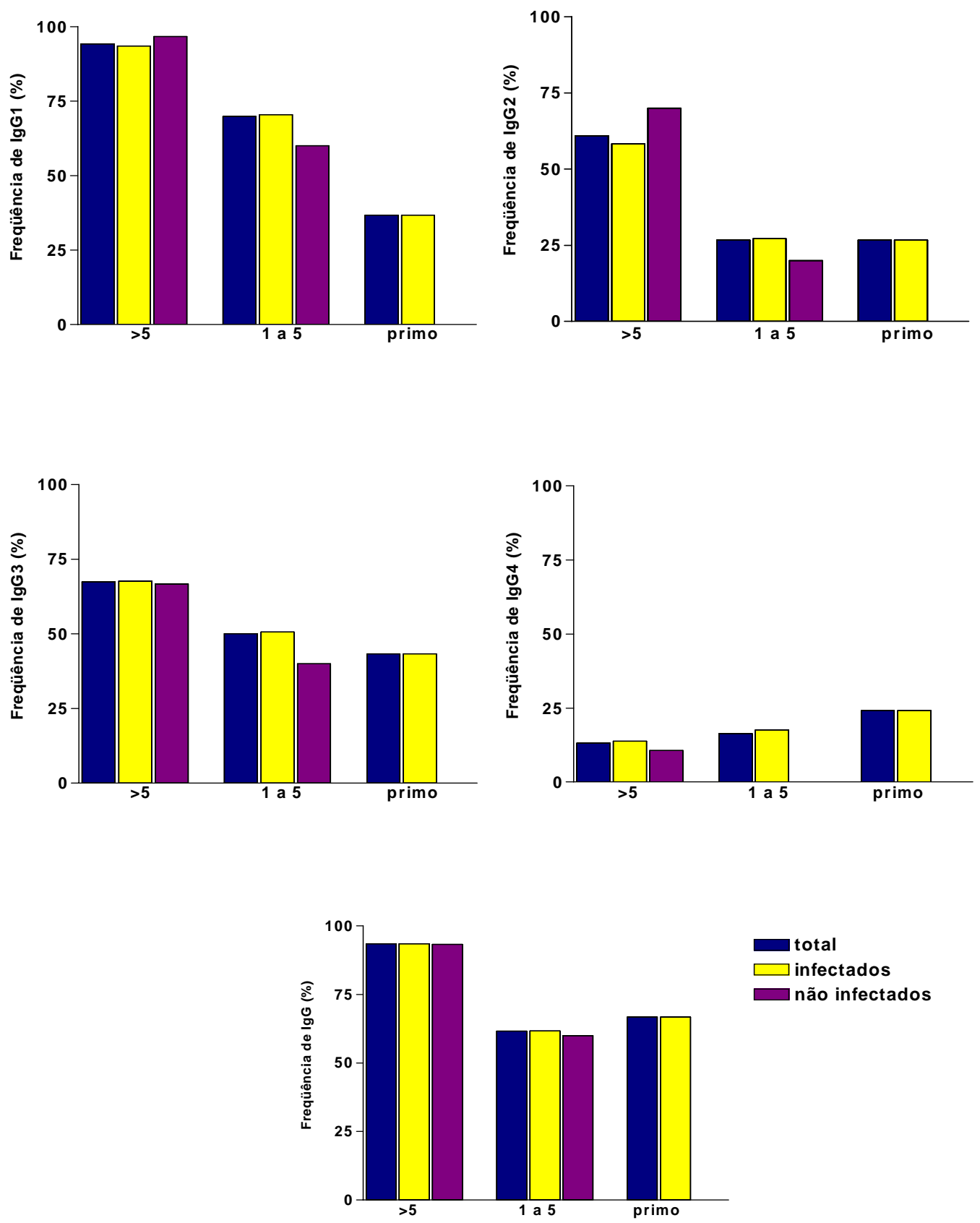

Fig. 5. Freqüências de amostras de soro positivas para anticorpos $\lg G$ e subclasses $\operatorname{lgG} 1, \lg G 2$, IgG3 e IgG4 anti-formas eritrocitárias de $P$. falciparum no ELISA no total de 270 indivíduos e considerando a presença ou não de infecção por Plasmodium distribuídas entre os grupos de indivíduos com mais de 5 malárias anteriores $(>5)(n=138)$, de uma a cinco malárias anteriores (1 a 5) $(n=86)$ e de primo-infectados (primo) $(\mathrm{n}=30)$. 
A freqüência de amostras positivas para anticorpos lgG2 foi significantemente maior no grupo de indivíduos com mais de 5 malárias anteriores do que nos grupos de 1 a 5 e primo-infectados, 60,9\%, 27,2\% e $26,7 \%$, respectivamente $\left(\chi^{2}=29,7 \%, P<0,0001\right)$, apesar de não terem diferido se os indivíduos estavam ou não infectados $(P>0,05)$.

As freqüências de amostras positivas para anticorpos IgG3 também foi significantemente maior no grupo de indivíduos com mais de 5 malárias anteriores do que nos grupos de 1 a 5 e primo-infectados, 67,4\%, 50,0\% e $43,3 \%$ respectivamente $\left(\chi^{2}=9,90 \%, P=0,007\right)$, apesar de não terem diferido se os indivíduos estavam ou não infectados $(P>0,05)$.

O oposto foi observado entre as freqüências de amostras positivas para anticorpos lgG4, que apesar de não diferirem significantemente foram maiores nos grupos de indivíduos relatando de 1 a 5 malárias anteriores e de primo-infectados, $16,4 \% 24,1 \%$ respectivamente do que no grupo com mais de 5 malárias anteriores, $13,1 \%\left(\chi^{2}=2,48 \%, P=0,290\right)$.

As freqüências de amostras positivas para anticorpos IgG também foi significantemente maior no grupo de indivíduos com mais de 5 malárias anteriores do que nos grupos de 1 a 5 e primo-infectados, 93,5\%, 61,7\% e $66,7 \%$, respectivamente $\left(\chi^{2}=36,5, P<0,0001\right)$. Também não houve diferença significante entre os indivíduos infectados e não infectados $(P>0,05)$.

Também analisamos os níveis de anticorpos lgG em índice de reatividade e das subclasses de IgG em concentração e os níveis de avidez nos diferentes grupos de malárias anteriores. As figuras 6 e 7 apresentam os resultados dessas análises. 

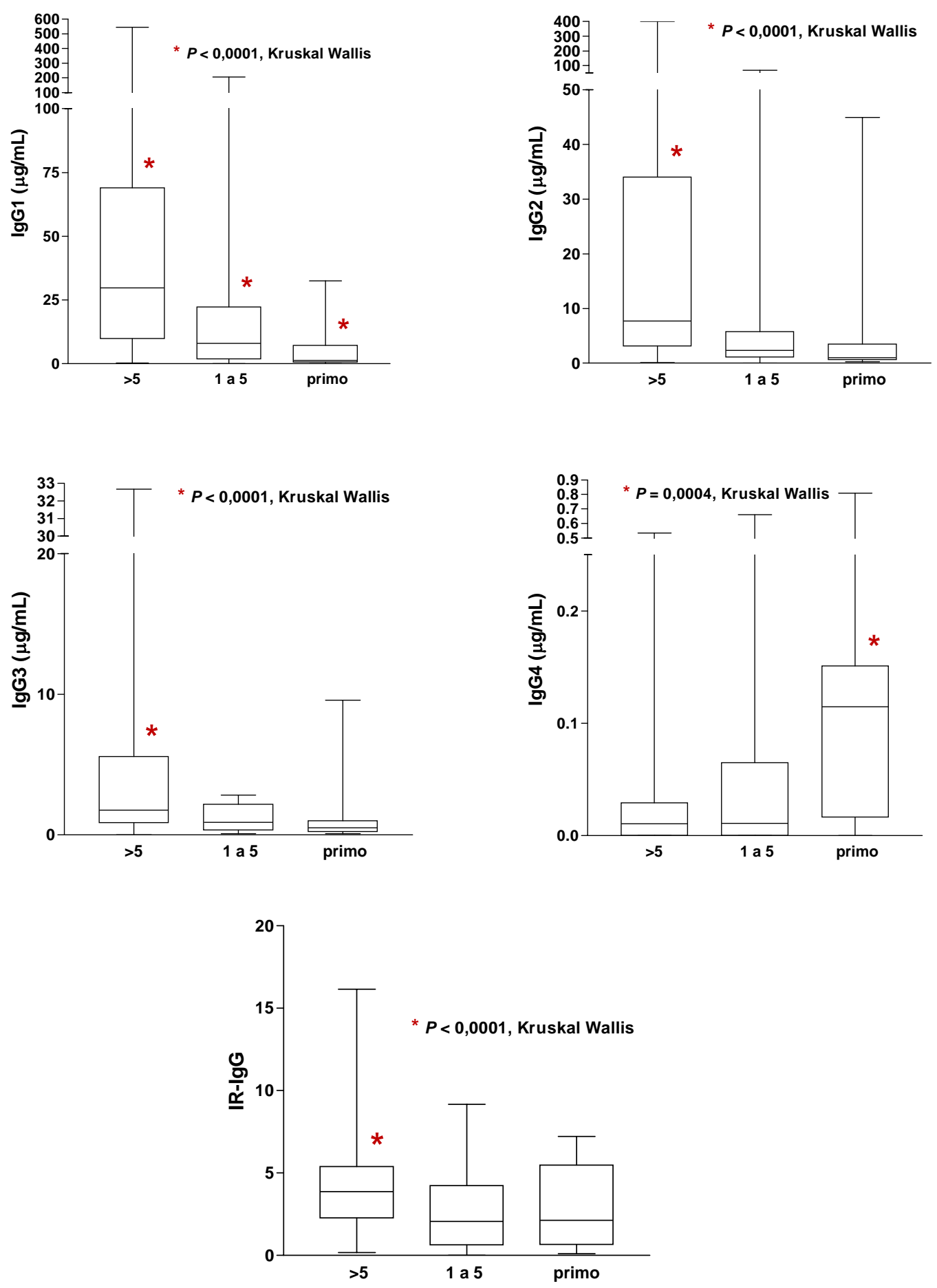

Fig. 6. Comparação dos níveis dos anticorpos IgG (em índice de reatividade (IR)) e das subclasses $\lg G 1$, lgG2, lgG3 e lgG4 anti-formas eritrocitárias de $P$. falciparum (em concentração, $\mu \mathrm{g} / \mathrm{mL}$ ) entre os grupos de indivíduos com mais de 5 malárias anteriores (>5) ( $n=138)$, de uma a cinco malárias anteriores (1 a 5) $(n=86)$ e de primo-infectados (primo) $(n=30)$ obtidos no ELISA. 
Observamos na figura 6 que os níveis de anticorpos $\lg G$ expressos como medianas dos IRs aumentaram significantemente em relação ao número de malárias anteriores, sendo 3,86 no grupo de indivíduos com mais de 5 malárias anteriores, 2,06 no grupo de uma a cinco malárias e 2,13 grupo de primo-infectados. Apesar de diferenças terem sido significantes apenas entre os grupos com mais de 5 malárias anteriores em relação aos outros dois grupos $(P<0,0001)$.

Os níveis de anticorpos lgG1 expressos como medianas das concentrações aumentaram significantemente em relação ao número de malárias anteriores, sendo $29,7 \mu \mathrm{g} / \mathrm{mL}$ no grupo de indivíduos com mais de 5 malárias anteriores, 8,07 $\mu \mathrm{g} / \mathrm{mL}$ no grupo de uma a cinco malárias e 1,29 $\mu \mathrm{g} / \mathrm{mL}$ no grupo de primo-infectados $(P<0,0001)$.

Os níveis de anticorpos lgG2 e lgG3 também aumentaram com o número de malárias anteriores, medianas de $\operatorname{lgG} 2,7,68,2,33,1,03 \mu \mathrm{g} / \mathrm{mL}$ e de IgG3, 1,77, 0,90 e 0,51 $\mu \mathrm{g} / \mathrm{mL}$ nos grupos com mais de 5 malárias anteriores, de uma a cinco malárias e de primo-infectados, respectivamente. Apesar de diferenças terem sido significantes apenas entre os grupos com mais de 5 malárias anteriores em relação aos outros dois grupos $(P<0,0001)$. 
Os níveis de anticorpos lgG4 diminuíram com o número de malárias anteriores, 0,011, 0,011 e 0,1145 $\mu \mathrm{g} / \mathrm{mL}$ nos grupos com mais de 5 malárias anteriores, de uma a cinco malárias e de primo-infectados, respectivamente $(P=0,0004)$. Resultados também significantes de correlação negativa entre anticorpos lgG4 e número de malárias anteriores no teste de correlação de Spearman (tabela 6).

Observamos na figura 7 que os níveis de avidez dos anticorpos lgG1 aumentaram significantemente em relação ao número de malárias anteriores, sendo $71,7 \%$ no grupo de indivíduos com mais de 5 malárias anteriores, $52,2 \%$ no grupo de uma a cinco malárias e $22,9 \%$ no grupo de primo-infectados $(P<0,0001)$. Correlação positiva e significante também foi obtida no teste de correlação de Spearman entre número de malárias anteriores e níveis de avidez de lgG1 e de lgG (tabela 6).

Já os níveis de avidez dos anticorpos lgG, $\lg G 2$, lgG3 e $\lg G 4$ não diferiram com o número de malárias anteriores $(P>0,05)$. 

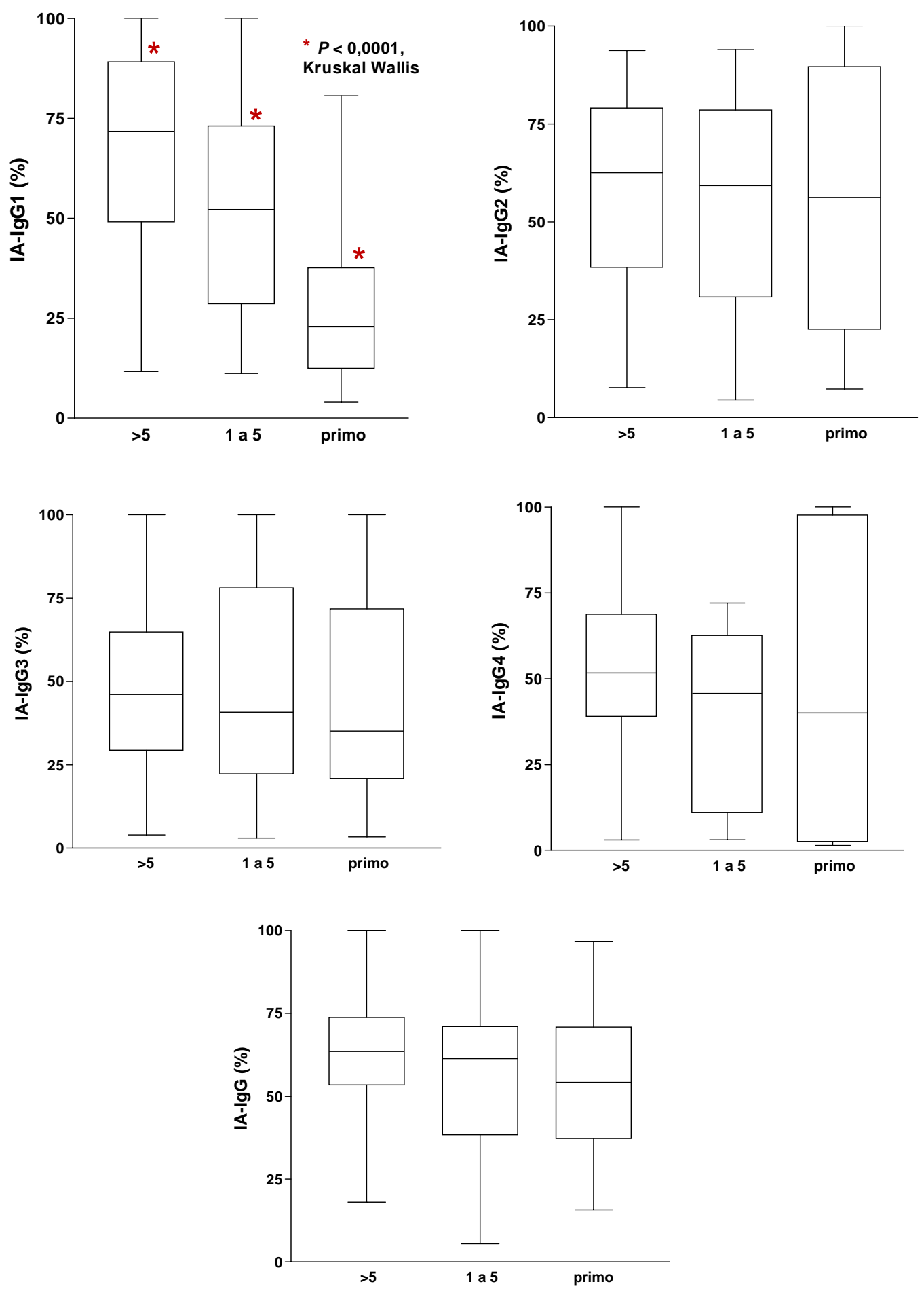

Fig. 7. Comparação dos níveis de avidez (IA) dos anticorpos IgG e das subclasses lgG1, IgG2, IgG3 e lgG4 anti-formas eritrocitárias de $P$. falciparum entre os grupos de indivíduos com mais de 5 malárias anteriores $(>5)(n=138)$, de uma a cinco malárias anteriores (1 a 5) $(n=86)$ e de primo-infectados (primo) $(n=30)$ obtidos no ELISA. 


\subsection{ANTICORPOS IgE, IgM, IgA}

Na tabela 7 apresentamos os resultados de anticorpos $\lg \mathrm{M}$, $\lg \mathrm{A}$ e $\lg \mathrm{E}$ quando testadas todas as amostras de soro das áreas endêmicas de malária, considerando a presença de plasmódio, definida pela positividade em pelo menos um método para pesquisa de plasmódios, gota espessa e/ou $\mathrm{QBC}^{\circledR}$.

Tabela 7. Resultados das freqüências (\%) de positivos e dos índices de reatividade (IR) (em mediana) de anticorpos $\operatorname{lgM}$, IgA e $\operatorname{lgE}$ anti-formas eritrocitárias de $P$. falciparum obtidos no ELISA com amostras de soros de indivíduos residentes em áreas endêmicas de malária divididos pelos resultados da pesquisa de plasmódios pela gota espessa e $\mathrm{QBC}^{\circledR}$.

\begin{tabular}{|c|c|c|c|c|c|c|c|c|c|}
\hline \multirow{2}{*}{\multicolumn{3}{|c|}{ ANTICORPOS }} & \multicolumn{7}{|c|}{ RESULTADOS DA PARASITEMIA } \\
\hline & & & \multirow[t]{2}{*}{ Plasmodium+ } & \multirow{3}{*}{$\frac{\mathrm{Pf}+}{153}$} & \multirow{3}{*}{$\frac{\mathrm{PfPv}^{+}}{27}$} & \multirow{3}{*}{$\frac{P v}{51}$} & \multirow{3}{*}{$\frac{\mathrm{Pm}}{2}$} & \multirow{3}{*}{$\frac{\mathrm{Neg}}{37}$} & \multirow{3}{*}{$\begin{array}{c}\text { Total } \\
270\end{array}$} \\
\hline & & & & & & & & & \\
\hline & To & & 233 & & & & & & \\
\hline \multirow[t]{4}{*}{$\lg M$} & IF & & 0,95 & 1,00 & 0,73 & 0,93 & 1,15 & 1,04 & 0,95 \\
\hline & Pos & $\mathrm{N}$ & 108 & 75 & 8 & 24 & 1 & 20 & 128 \\
\hline & & $\%$ & 46,4 & 49,0 & 29,6 & 47,1 & 50,0 & 54,1 & 47,4 \\
\hline & $\overline{\text { To }}$ & & 119 & 91 & 13 & 15 & - & 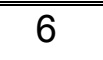 & 125 \\
\hline \multirow[t]{4}{*}{$\lg A$} & IF & & 0,90 & 0,96 & 0,74 & 0,97 & - & 0,82 & 0,90 \\
\hline & Pos & $\mathrm{N}$ & 51 & 42 & 2 & 7 & - & 3 & 54 \\
\hline & & $\%$ & 42,9 & 46,2 & 15,4 & 46,7 & - & 50,0 & 43,2 \\
\hline & To & & 208 & 130 & 26 & 51 & 1 & 30 & 238 \\
\hline \multirow[t]{3}{*}{$\lg E$} & IF & & 0,64 & 0,75 & 0,21 & 0,57 & 0,08 & 1,41 & 0,66 \\
\hline & Pos & $\mathrm{N}$ & 79 & 53 & 8 & 18 & - & 15 & 94 \\
\hline & & $\%$ & 37,9 & 40,8 & 30,8 & 35,3 & - & 50,0 & 39,5 \\
\hline
\end{tabular}

(Pf: P. falciparum; Pv: P. vivax; Pm: P. malariae; Neg: negativo). 
As freqüências de anticorpos $\lg M, \lg A$ e $\lg E$ foram maiores nos indivíduos não infectados do que nos indivíduos infectados, mas sem diferença significante $(P>0,05)$. Quando consideramos a espécie de Plasmodium infectante, também não foram observadas diferenças significantes das freqüências de positivos para os anticorpos $\lg M, \lg A$ e $\lg E$ $(P>0,05)$.

Os níveis de anticorpos $\lg M$ e $\lg A$, calculados em IRs, não diferiram entre os indivíduos infectados e os indivíduos não infectados $(P>0,05)$. Os níveis de anticorpos $\lg E$ calculados em concentração $(\mu \mathrm{g} / \mathrm{mL})$, também não diferiram entre infectados e os não infectados (Tabela 8).

Tabela 8. Resultados das medianas dos níveis de anticorpos IgE anti-formas eritrocitárias de $P$. falciparum no ELISA com 238 amostras de soro de indivíduos de área endêmica de malária. IR=índice de reatividade; $[\mathrm{Ig}]=$ concentração da subclasse em $\mu \mathrm{g} / \mathrm{mL} ; P=$ probabilidade a $95 \%$ de existir diferença entre os grupos (teste de Mann-Whitney).

\begin{tabular}{clcccc}
\hline \hline & & \multicolumn{4}{c}{ Níveis de anticorpos } \\
\cline { 3 - 6 } anticorpo & População & {$[\mathrm{lg}]$} & $P$ & $\mathrm{IR}^{*}$ & $P$ \\
& & $(\mu \mathrm{g} / \mathrm{mL})$ & & & \\
\hline \hline lgE & total & 0,05 & & 0,68 & \\
& infectados & 0,05 & 0,697 & 0,64 & 0,701 \\
& não infectados & 0,07 & & 1,41 & \\
\hline \hline
\end{tabular}


Correlacionamos os índices de reatividade de $\lg M, \lg A$ e $\lg E$, as concentrações dos anticorpos IgE com as variáveis preditoras de exposição à malária, como idade, número de malárias anteriores e tempo de permanência na área endêmica não observamos nenhuma correlação significante com os resultados de anticorpos $(P>0,05)$ (Correlação de Spearman).

Na figura 8 mostramos as freqüências de anticorpos $\lg M, \lg A$ e $\lg E$ de acordo com o número de episódios anteriores de malária relatados pelos indivíduos.

Os primo-infectados apresentaram maior freqüência de anticorpos IgM (70\%) dos que os que relataram de 1 a 5 malárias $(47,7 \%)$ e os que relataram mais de 5 malárias $(42,8 \%)\left(\chi^{2}=7,33 ; P=0,026\right)$. Apesar de não terem diferido se os indivíduos estavam ou não infectados $(P>0,05)$.

A freqüência de anticorpos $\lg A$ não diferiu com o número de malárias anteriores $(P>0,05)$.

A freqüência de amostras positivas para os anticorpos lgE foi significantemente maior no grupo de indivíduos com mais de 5 malárias do que nos grupos de 1 a 5 malárias e primo-infectados, 56,5\%, 33,8\% e $41,4 \%$, respectivamente $\left(\chi^{2}=11,6 P=0,003\right)$. Apesar de não terem diferido se os indivíduos estavam ou não infectados $(P>0,05)$.

Também analisamos os níveis de anticorpos $\lg M$ e $\lg \mathrm{A}$ em índice de reatividade e de $\operatorname{lgE}$ em concentração $(\mu \mathrm{g} / \mathrm{mL})$ nos diferentes grupos de malárias anteriores (figura 9). 
Os níveis de anticorpos lgM e lgA diminuíram com número de malárias anteriores, medianas de $\lg M$ 0,90, 0,98 e 1,28 e de $\operatorname{lgA} 0,82,0,96$ e 1,02 nos grupos com mais de 5 malárias anteriores, de uma a cinco malárias e de primo-infectados, respectivamente, apesar que não foram observadas diferenças significantes entre os grupos $(P>0,05)$.

Os níveis de anticorpos IgE diminuíram com o número de malárias anteriores, 0,049, 0,049 e 0,063 $\mu \mathrm{g} / \mathrm{mL}$ nos grupos de 5 malárias anteriores, de uma cinco malárias e de primo-infectados, respectivamente, também sem diferenças significantes entre os grupos $(P>0,05)$. 

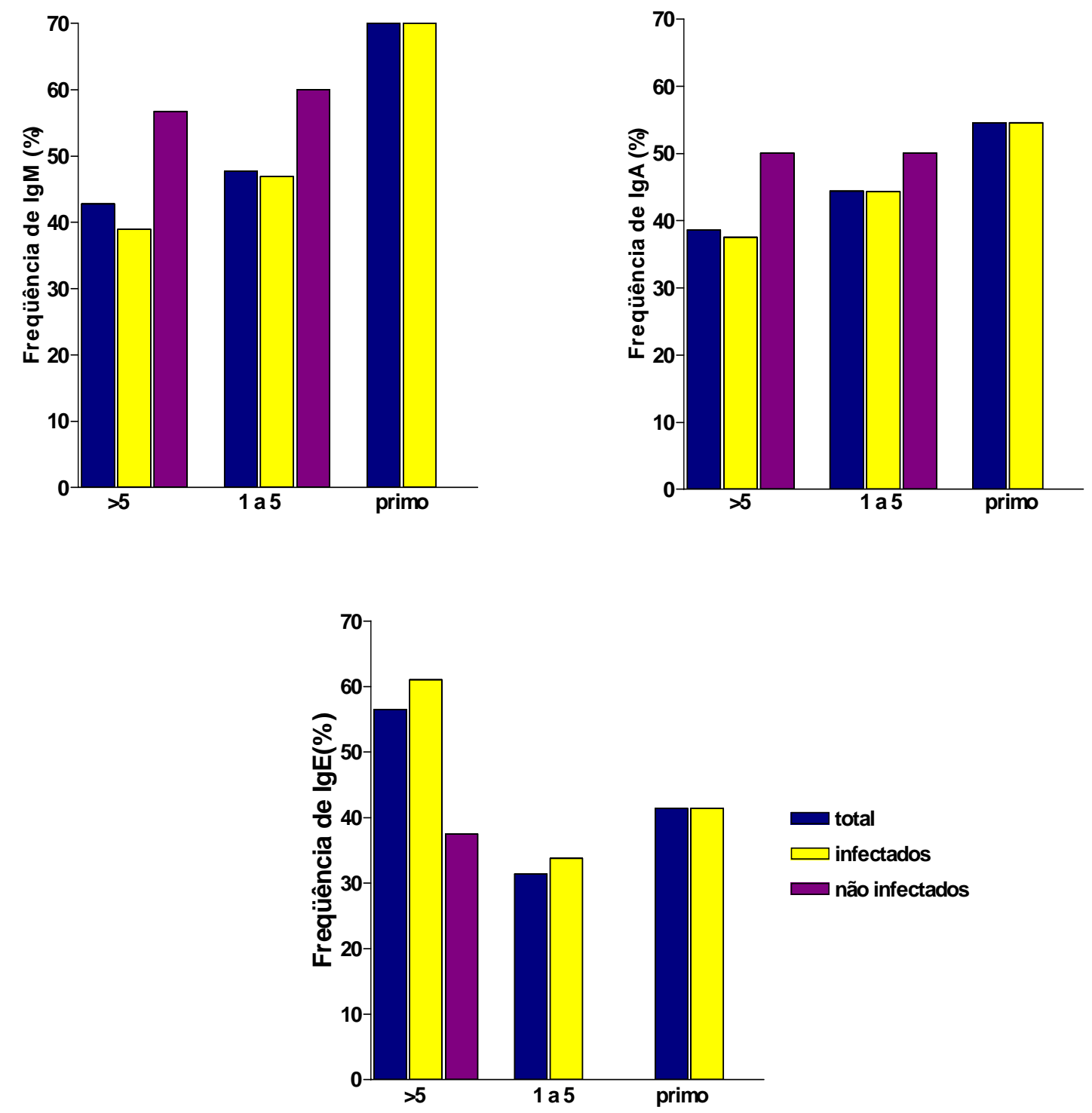

Fig. 8. Freqüências de amostras de soros positivas anticorpos $\lg M, \lg A$ e $\lg E$ antiformas eritrocitárias de $P$. falciparum no ELISA no total de 270 indivíduos e considerando a presença ou não de infecção por Plasmodium distribuídas entre os grupos de indivíduos com mais de 5 malárias anteriores $(>5)(n=138)$, de uma a cinco malárias anteriores (1 a 5) $(n=86)$ e de primo-infectados (primo) $(n=30)$. 

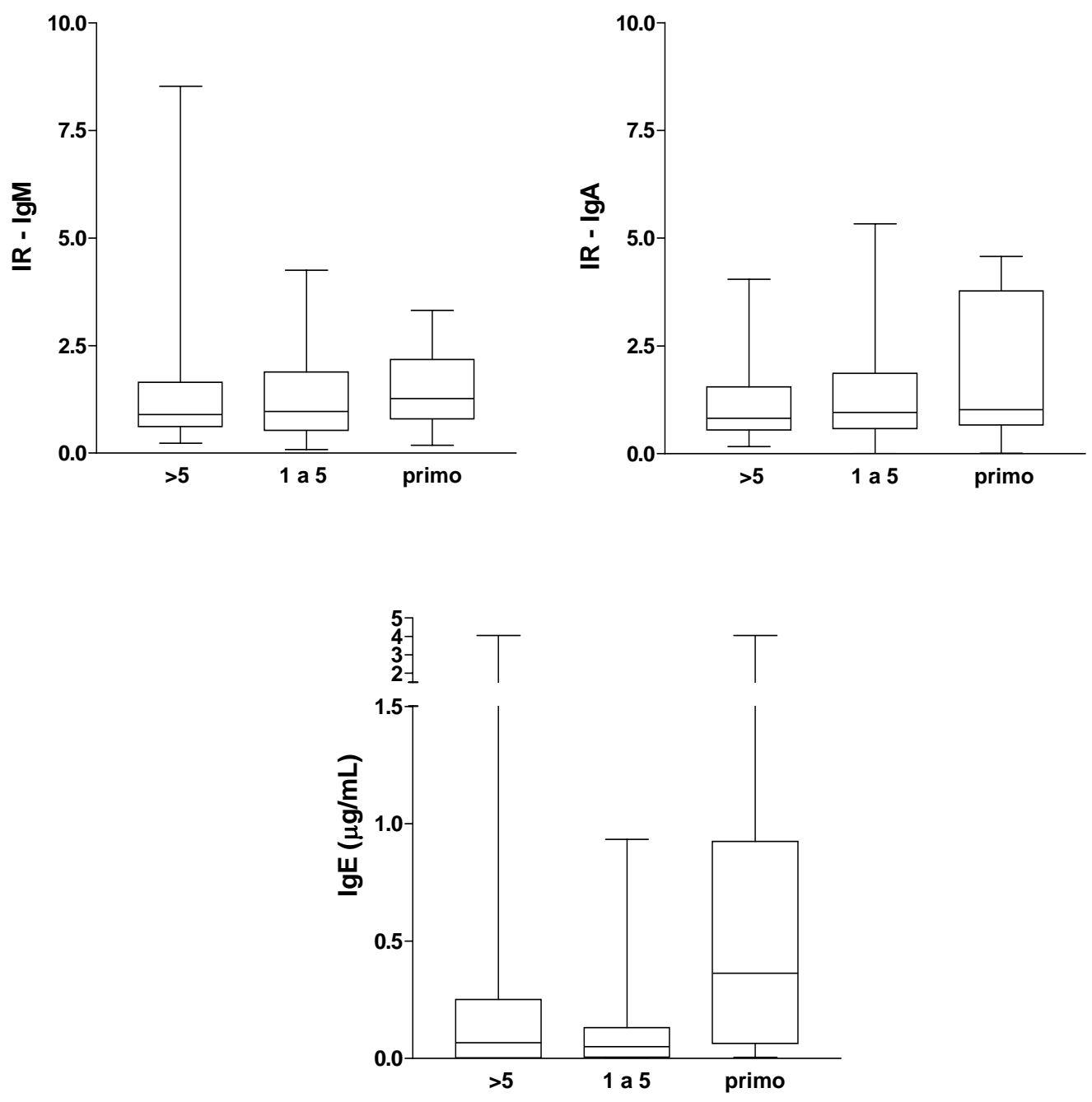

Fig. 9. Comparação dos níveis dos anticorpos lgM e lgA (em índice de reatividade (IR)) e de IgE anti-formas eritrocitárias de $P$. falciparum (em concentração, $\mu \mathrm{g} / \mathrm{mL}$ ) entre os grupos de indivíduos com mais de 5 malárias anteriores $(>5)(n=138)$, de uma a cinco malárias anteriores (1 a 5) $(n=86)$ e de primo-infectados (primo) $(n=30)$ obtidos no ELISA. 
De 66 amostras de soro foram determinados os níveis de $\lg E$ e $\lg A$ totais por nefelometria. A mediana dos níveis de $\lg E$ foi de $1.095 \mathrm{Ul} / \mathrm{mL}$, muito acima dos níveis normais que são abaixo de $100 \mathrm{Ul} / \mathrm{mL}$; apenas quatro amostras mostraram níveis normais de $\lg E$ total. Entre as 62 amostras com níveis elevados, 40 foram positivas para anticorpos lgE anti- $P$. falciparum $(64,5 \%)$ e 22 foram negativas $(35,5 \%)(z=3.05 ; P=0,002)$.

Os níveis de $\lg \mathrm{A}$ total ficaram dentro da normalidade com mediana de 2,00 g/L, sendo que os níveis normais estão entre 0,7 a $4 \mathrm{~g} / \mathrm{L}$. Apenas três amostras de soro estavam abaixo da normalidade e quatro acima de $4 \mathrm{~g} / \mathrm{L}$. 


\subsection{DETERMINAÇÃO DO PERFIL DE RESPOSTA HUMORAL EM DIFERENTES FORMAS CLÍNICAS DA MALÁRIA}

Para analisar as diferenças de resposta humoral entre indivíduos com diferentes formas clínicas de malária, foram determinadas todas as classes e subclasses de imunoglobulinas específicas para $P$. falciparum em 233 amostras de soro de indivíduos infectados divididos em:

a) Indivíduos com complicações clínicas por malária $(n=70), 52$ infectados por $P$. falciparum e 18 por $P$. vivax (MC= malária complicada);

b) Indivíduos sem complicações clínica (n=148), 92 infectados por $P$. falciparum, 32 por $P$. vivax, 1 por $P$. malariae e 23 por $P$. falciparum e $P$. vivax (MNC= malária não complicada)

c) Indivíduos assintomáticos ( $\mathrm{n=15),} 9$ infectados por $P$. falciparum, 1 por $P$. vivax, 1 por $P$. malariae e 4 por $P$. falciparum e $P$. vivax (AS= malária assintomática).

Os resultados em freqüências de amostras positivas para as diferentes classes e subclasses de anticorpos anti- $P$. falciparum são apresentados na figura 10 . 
$\square \mathrm{MC} \square \mathrm{MNC} \square \mathrm{AS}$

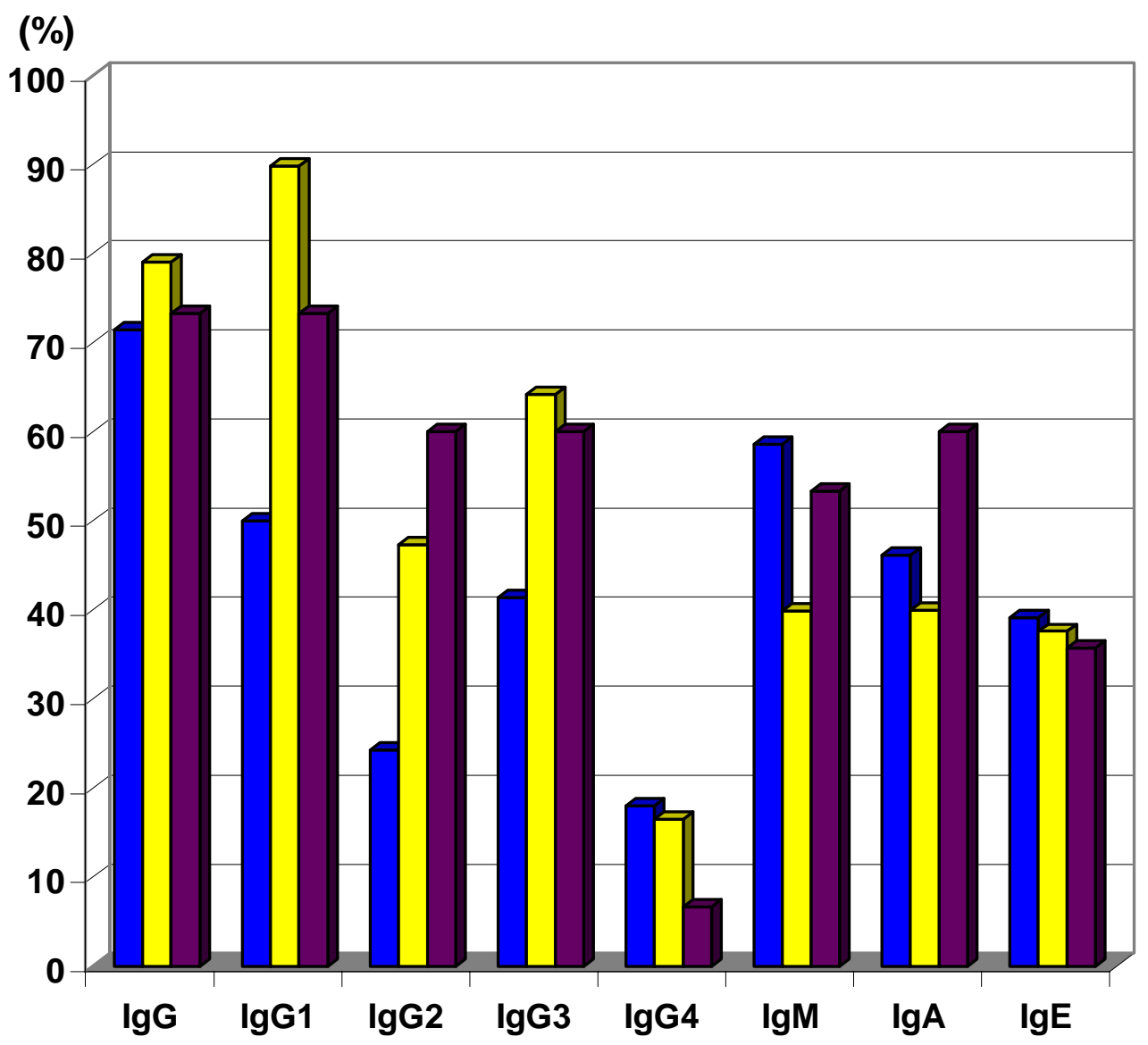

Fig. 10. Freqüências dos anticorpos $\lg G, \lg G 1, \lg G 2$, $\lg G 3, \lg G 4, \lg M$, $\lg A$ e $\lg E$ anti-formas eritrocitárias de $P$. falciparum no ELISA com 233 amostras de soro de indivíduos com malária, 70 com complicações clínicas por malária (MC), 148 sem complicações clínicas (MNC) e 15 assintomáticos (AS).

Os anticorpos IgG1 predominaram nos grupos MNC e AS, 89,9\% e 73,3\%,respectivamente com diferença significante em relação ao grupo MC, $50,0 \%\left(\chi^{2}=42,5 ; P<0,0001\right)$.

Os anticorpos IgG2 predominaram nos grupos MNC e AS, 47,3\% e $60,0 \%$, respectivamente com diferença significante em relação ao grupo MC, $24,3 \%\left(\chi^{2}=12,7 ; P=0,0017\right)$. 
Os anticorpos IgG3 predominaram nos grupos MNC e AS, 64,2\% e $60,0 \%$, respectivamente com diferença significante em relação ao grupo MC, $41,4 \%\left(\chi^{2}=10,1 ; P=0,0064\right)$.

O oposto foi observado para os anticorpos IgG4 que predominaram nos grupos MNC e MN, $18 \%$ e 16,5\%, respectivamente, em relação ao grupo AS, $6,7 \%$, apesar da diferença não ter sido significante $\left(\chi^{2}=1,14 ; P=0,57\right)$.

Os anticorpos IgM predominaram no grupo $\mathrm{MC}, 58,6 \%$ com diferença significante em relação aos grupos MNC e AS, 39,9\% e 53,3\%, respectivamente $\left(\chi^{2}=7,00 ; P=0,030\right)$.

Em relação aos anticorpos $\lg G$, $\lg A$ e $\lg E$ não houve diferença significante entre os grupos $(P>0,05)$.

Na figura 11 apresentamos as freqüências de cada subclasse e de IgG de alta avidez e baixa avidez divididos pelos grupos de diferentes formas clínicas de malária. Anticorpos lgG e lgG1 de alta avidez predominaram significantemente nos grupos MNC e AS e de baixa avidez, predominaram no grupo MC (IgG, $\chi^{2}=16,5, P=0,0003$ e $\left.\lg G 1, \chi^{2}=16,4, P=0,0003\right)$. O mesmo foi observado para os anticorpos lgG2, apesar da diferença não ter sido significante $(P>0,05)$. Entre os anticorpos lgG3 predominaram os de baixa avidez independente da forma clínica, apesar de não significante $(P>0,05)$. Os níveis de avidez dos anticorpos IgG4 não diferiram no grupo MNC, e no grupo MC predominaram os de baixa avidez, mas sem significância $(P>0,05)$. Apenas um dos indivíduos assintomáticos foi positivo para anticorpos IgG4, e estes foram de alta avidez. 
$\lg G 1$

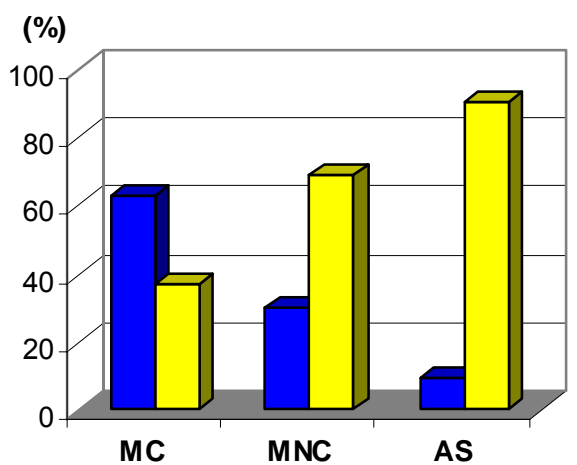

$\lg G 3$

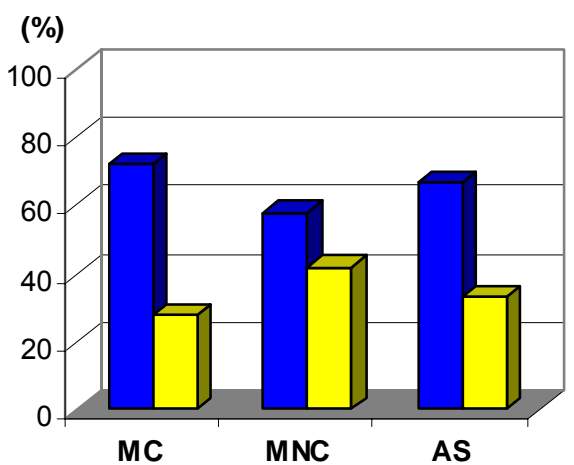

$\lg \mathbf{l g}$

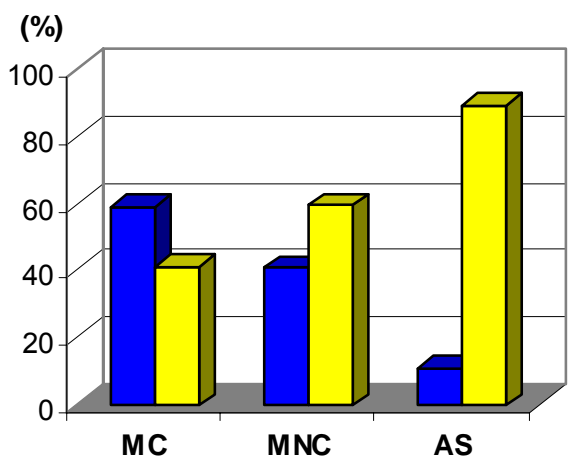

$\lg$ G4

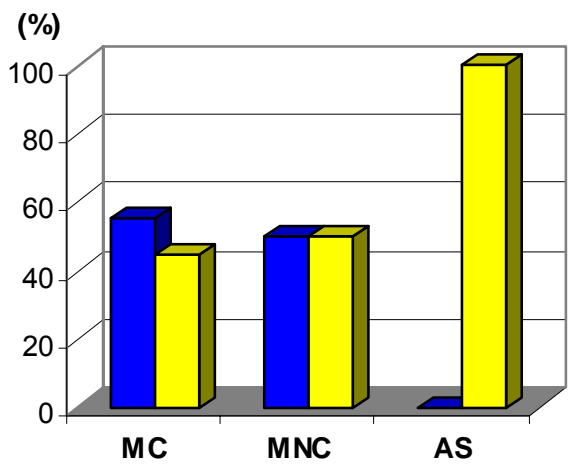

$\lg G$

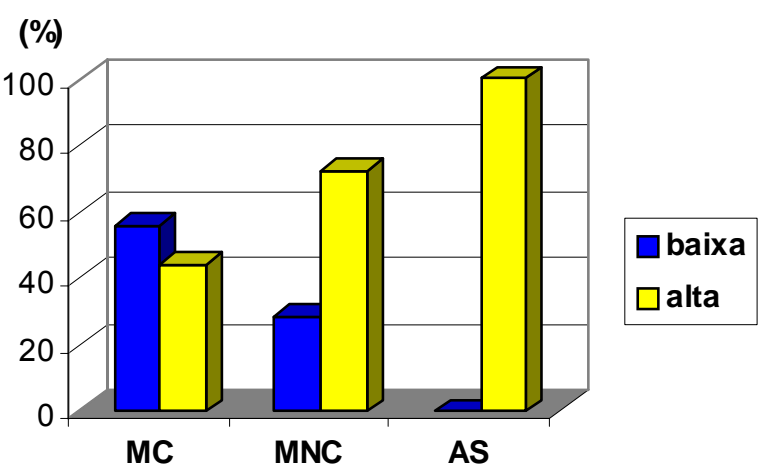

Fig. 11. Freqüências das subclasses $\lg G 1$, lgG2, $\lg G 3$ e $\lg G 4$ e de $\lg G$ anti-formas eritrocitárias de $P$. falciparum de baixa avidez e de alta avidez divididas entre os indivíduos com malária complicada (MC) $(n=70)$, indivíduos sem complicações clínicas por malária (MNC) $(n=148)$ e indivíduos infectados assintomáticos (AS) $(n=15)$ testados no ELISA. 
Nas figuras 12 e 13 apresentamos a distribuição dos resultados das diferentes imunoglobulinas nos grupos MC, MNC e AS.

O perfil diferencial entre os grupos foi semelhante ao observado em freqüências de positividade para cada imunoglobulina. Os níveis de $\lg G 1$, $\lg G 2$, IgG3 foram maiores nos grupos MNC e AS do que no grupo MC $(P<0,0001)$. Os níveis de lgG4 não diferiram entre os grupos $(P>0,05)$. Já os níveis de $\lg M$ e $\lg E$ foram maiores no grupo $\mathrm{MC}(P=0,107, P=0,069$, respectivamente) e os níveis de $\lg G$ e $\lg A$ não diferiram entre os grupos $(P>0,05)$.

No quadro da figura 14 apresentamos os resultados das 233 amostras analisadas para cada imunoglobulina e divididas entre os três grupos de formas clínicas da malária. Assim, visualizamos o perfil de resposta humoral de cada indivíduo, reforçando as observações de um perfil de resposta predominante de $\operatorname{lgG} 1$, IgG2 e lgG3 nos grupos AS e MNC e de $\lg G 4$, IgE e IgM no grupo MC. 

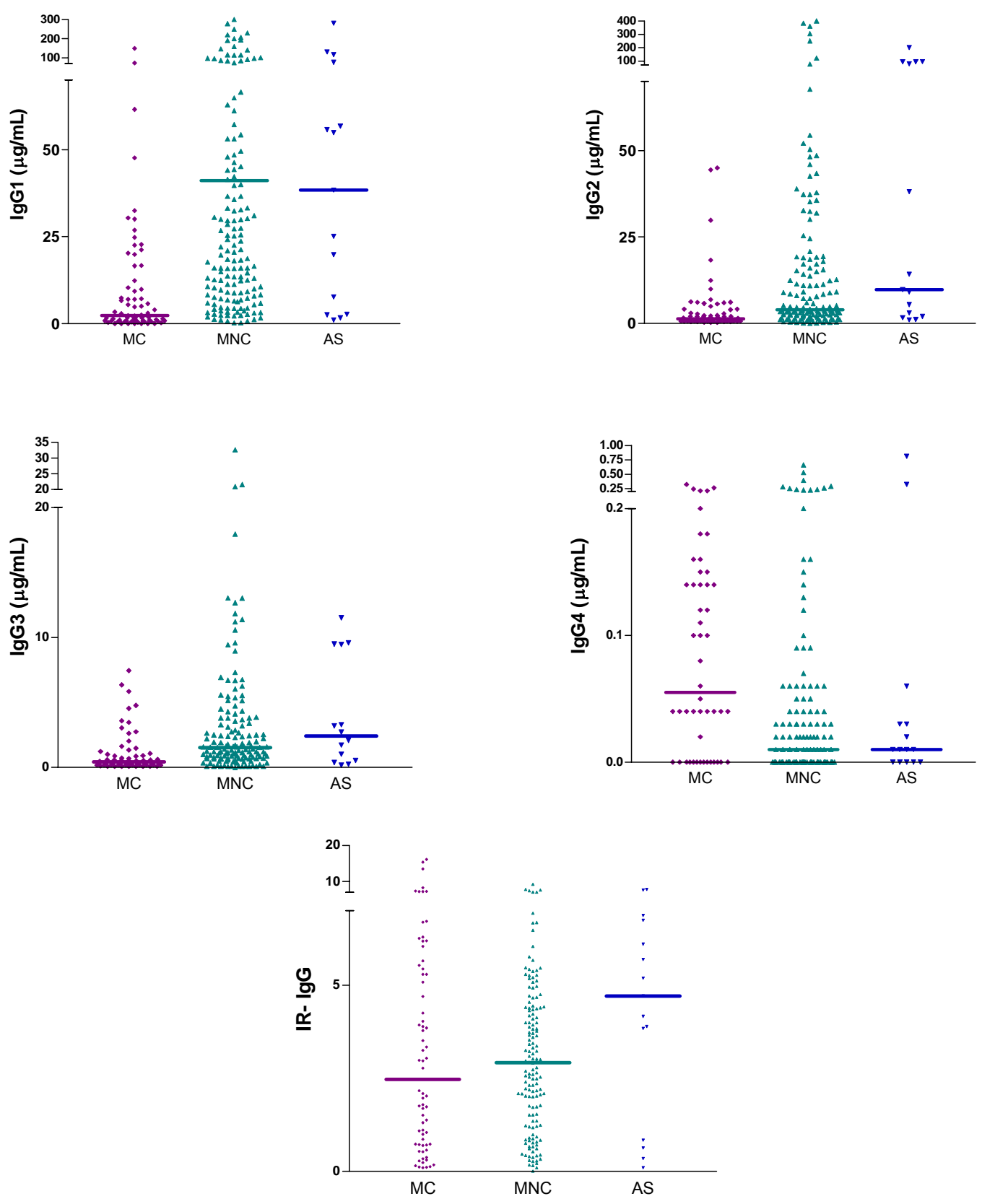

Fig. 12. Distribuição dos níveis dos anticorpos $\lg G$ e subclasses $\lg G 1$, $\lg G 2$, $\lg G 3$ e IgG4 anti-formas eritrocitárias de $P$. falciparum no ELISA. Resultados de IgG expressos em índices de reatividade (IR) e as subclasses expressos em concentração $(\mu \mathrm{g} / \mathrm{mL})$ entre os indivíduos com malária complicada (MC) $(n=70)$, indivíduos sem complicações clínicas por malária (MNC) $(n=148)$ e indivíduos com malária assintomáticos (AS) $(n=15)$. 

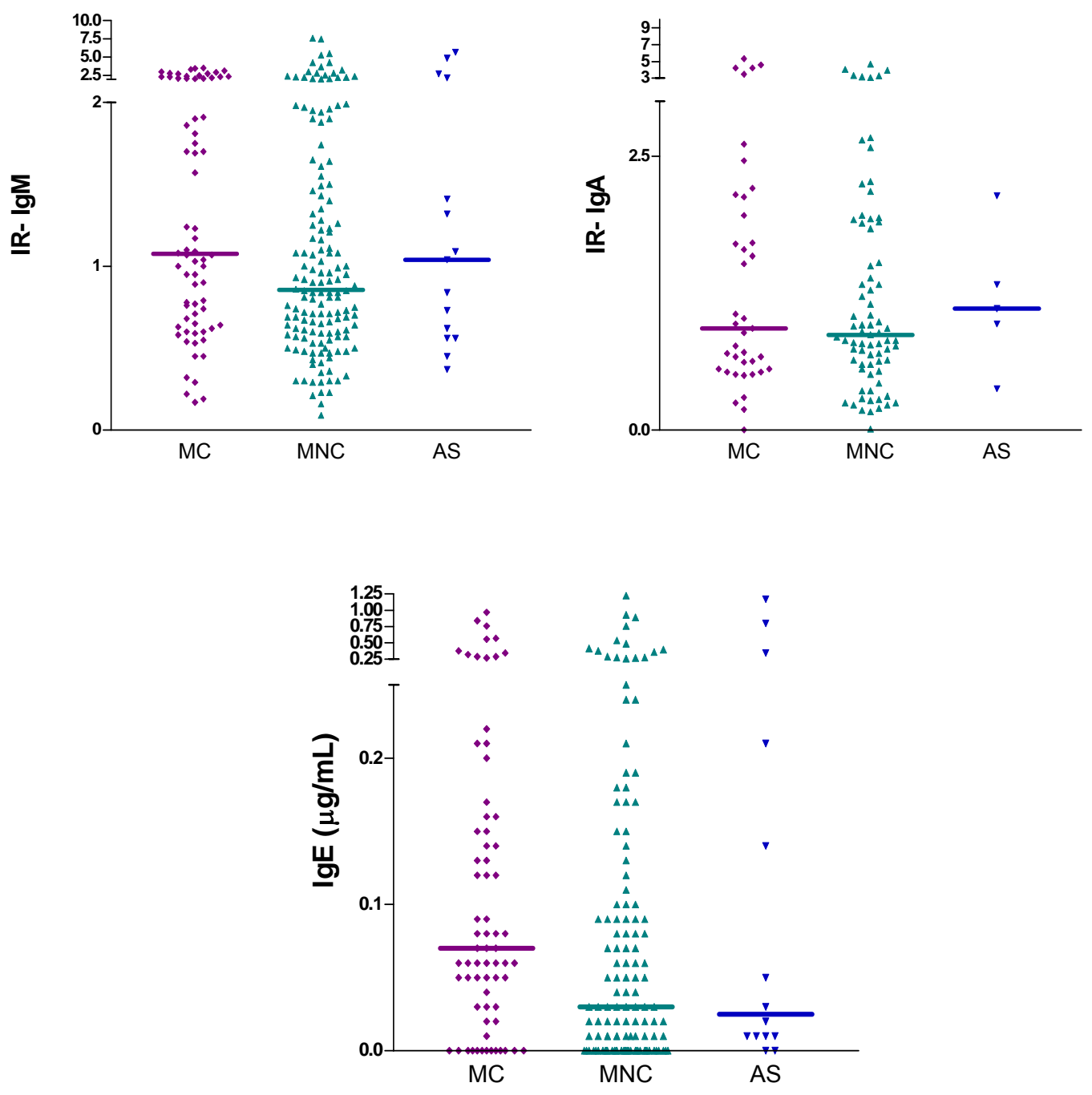

Fig. 13. Distribuição dos níveis dos anticorpos $\lg M$, $\lg A$ e $\lg E$ anti-formas eritrocitárias de $P$. falciparum no ELISA. Resultados de IgM e IgA estão expressos em índices de reatividade (IR) e de $\mathrm{IgE}$ em concentração $(\mu \mathrm{g} / \mathrm{mL})$ entre os indivíduos com malária complicada (MC) $(n=70)$, indivíduos sem complicações clínicas por malária (MNC) $(\mathrm{n}=138)$ e indivíduos com malária assintomática (AS) $(n=15)$. 


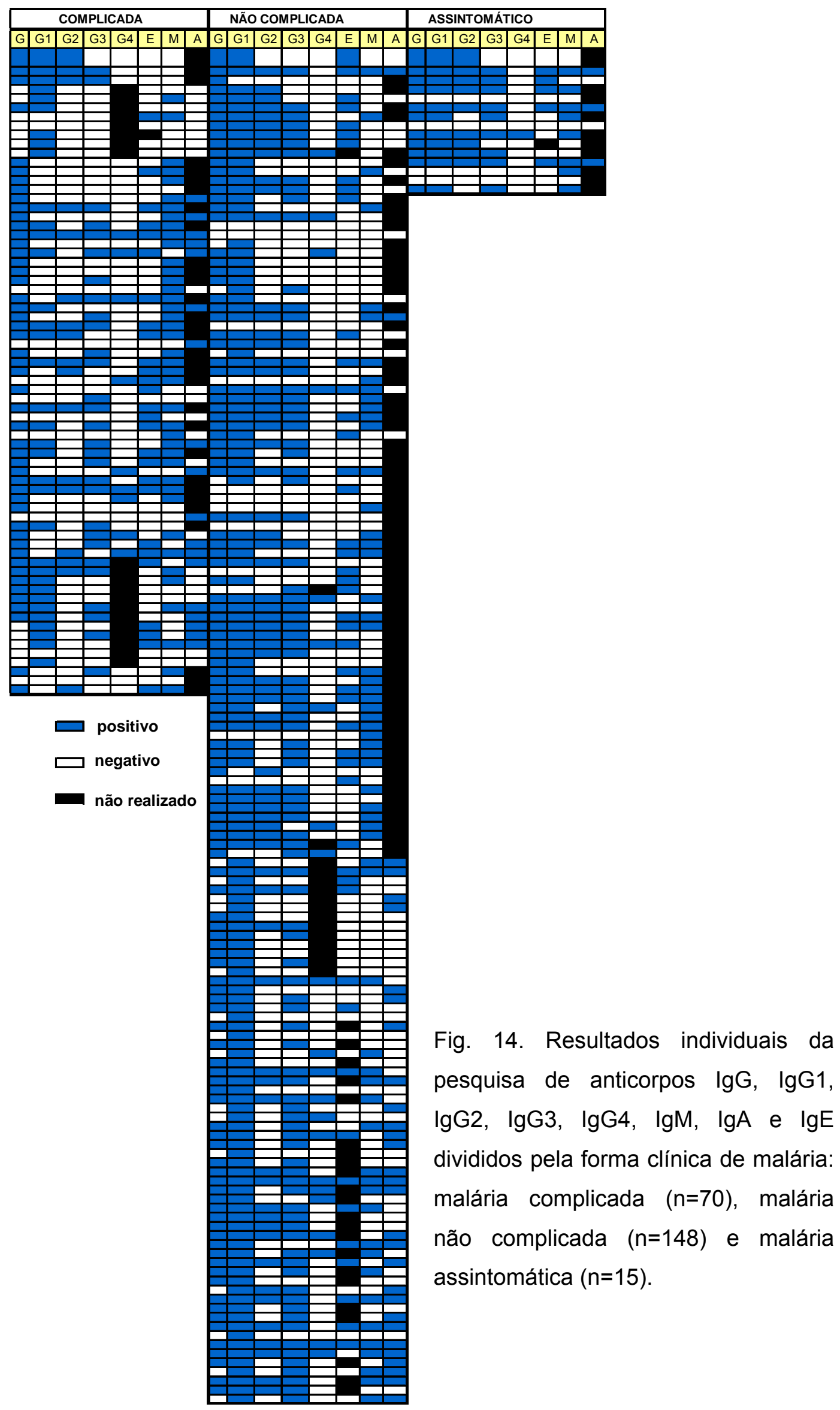


Analisamos também as interações entre as diferentes classes e subclasses de anticorpos frente aos três grupos de formas clínicas de malária (Tabela 9).

Tabela 9. Interações entre os níveis de diferentes classes e subclasses de anticorpos anti-formas eritrocitárias de $P$. falciparum entre os grupos de indivíduos com malária complicada, com malária não complicada e com malária assintomática. $\mathrm{G}=\lg G, \mathrm{G} 1=\lg \mathrm{G} 1, \mathrm{G} 2=\lg \mathrm{g} 2, \mathrm{G} 3=\lg \mathrm{G} 3, \mathrm{G} 4=\lg \mathrm{G} 4, \mathrm{E}=\lg \mathrm{E}$, $M=\lg M$.

\begin{tabular}{|c|c|c|c|c|}
\hline \multirow[b]{2}{*}{ Interações } & \multicolumn{3}{|c|}{ Forma clínica da malária } & \multirow{2}{*}{$\begin{array}{c}\text { Kruskal } \\
\text { Wallis }(p)\end{array}$} \\
\hline & complicada & $\begin{array}{c}\text { não } \\
\text { complicad }\end{array}$ & assintomática & \\
\hline G1G3/G2G4 & 2,16 & 3,35 & 1,70 & 0,061 \\
\hline G1G2G3/G4 & 0,36 & 9,12 & 32,1 & $<0,001$ \\
\hline G1G3 & 1,45 & 10,94 & 23,94 & $<0,0001$ \\
\hline G2G4 & 0,91 & 2,12 & 4,92 & $<0,0001$ \\
\hline EG4 & 0,16 & 0,06 & 0,06 & 0,0100 \\
\hline G2/G4 & 12,2 & 154,1 & 482,7 & $<0,0001$ \\
\hline G3/G4 & 4,29 & 39,79 & 82,83 & $<0,0001$ \\
\hline $\mathrm{EG} 4 / \mathrm{G} 2$ & 0,106 & 0,008 & 0,01 & $<0,0001$ \\
\hline MEG4 & 2,81 & 1,91 & 1,52 & 0,16 \\
\hline$M / G$ & 0,565 & 0,39 & 0,36 & 0,032 \\
\hline G/M & 1,77 & 2,56 & 2,81 & 0,031 \\
\hline G1G2G3/MEG4 & 5,32 & 13,87 & 18,87 & $<0,0001$ \\
\hline$E / G$ & 0,31 & 0,18 & 0,29 & 0,021 \\
\hline $\mathrm{G} / \mathrm{E}$ & 2,70 & 2,98 & 3,80 & 0,078 \\
\hline
\end{tabular}


Observamos que nos grupos MNC e AS predominaram as interações dos anticorpos $\operatorname{lgG} 1$, $\lg G 2$ e $\lg G 3$, enquanto no grupo MC complicada predominaram as interações entre lgG4 e lgE. Maiores razões dos níveis de IgG2 em relação a IgG4 predominam nos indivíduos assintomáticos e com malária não complicada.

\section{DETERMINAÇÃO DO POLIMORFISMO DO RECEPTOR FC $\gamma$ RIIA H/R $\mathbf{R}^{131}$}

Foi realizado um método de digestão com enzima de restrição específica do alelo para determinarmos a existência do polimorfismo Fc $\gamma$ RIIA H/R ${ }^{131}$ em 53 indivíduos. A freqüência do alelo H131 foi $67,9 \%(n=36)$, sendo 22,6\% $H / H(n=12)$ e 45,3\% H/R ( $n=24)$. O aminoácido arginina na posição (R/R) foi encontrado em 17 indivíduos (32,1\%) R/R.

$\mathrm{Na}$ figura 15 apresentamos os resultados da digestão do produto de PCR digerido com a enzima de restrição Bsh1236I (FnuDII) de algumas amostras com a presença ou ausência do polimorfismo no receptor Fc $\gamma$ RIIA H/R131.

As amostras de DNA dos 53 indivíduos foram testadas também por Nested-PCR para a pesquisa de Plasmodium, sendo que foram todas positivas. Assim, os pacientes foram divididos em dois grupos em relação à presença ou não de sintomas: sintomáticos $(n=35)$ e assintomáticos $(n=18)$.

Na tabela 10 apresentamos os resultados dos anticorpos lgG2 divididos entre os grupos de indivíduos sintomáticos e assintomáticos com e sem a presença do polimorfismo H131. 
Ao analisarmos estatisticamente os dados da tabela, encontramos que a freqüência de anticorpos lgG2 foi significantemente maior nos indivíduos assintomáticos $(76,9 \%)$ do que nos sintomáticos $(39,1 \%)(P=0,041$, teste de Fisher). Ao compararmos as medianas das concentrações de lgG2 nos grupos, observamos que essas foram maiores no grupo de indivíduos assintomáticos, com diferença significante entre os indivíduos que carregam o polimorfismo H131 $(78,7 \mu \mathrm{g} / \mathrm{mL}$ nos assintomáticos e $3,35 \mu \mathrm{g} / \mathrm{mL}$ nos sintomáticos) ( $T=311, P=0,02$, teste de Mann-Whitney).

Tabela 10. Resultados do ELISA para pesquisa de anticorpos IgG2 antiformas eritrocitárias de $P$. falciparum divididos nos grupos de indivíduos positivos para Plasmodium por Nested-PCR sintomáticos e assintomáticos e com $(H / H$ ou $H / R)$ e sem (R/R) o polimorfismo no receptor FcyRIIA $H^{131}$, determinado por PCR após digestão com enzima de restrição alelo específica.

\begin{tabular}{llccc}
\hline \multicolumn{1}{c}{ Grupos } & \multicolumn{1}{c}{ Alelo } & \multicolumn{3}{c}{ Anticorpos lgG2 } \\
& Fcy RIIA H131 & [ ] Md & N pos & \% pos \\
\hline \hline sintomáticos & $\mathrm{R} / \mathrm{R}(\mathrm{n}=12)$ & 4,0 & 5 & 41,7 \\
$(\mathrm{n}=35)$ & $\mathrm{H} / \mathrm{H}$ ou H/R $(\mathrm{n}=23)$ & 3,4 & 9 & 39,1 \\
\hline assintomáticos & $\mathrm{R} / \mathrm{R}(\mathrm{n}=5)$ & 38,1 & 4 & 80,0 \\
(n=18) & $\mathrm{H} / \mathrm{H}$ ou H/R $(\mathrm{n}=13)$ & 78,6 & 10 & 76,9 \\
\hline \hline
\end{tabular}

$\overline{M d}=$ mediana das concentrações em $\mu \mathrm{g} / \mathrm{mL}$ 


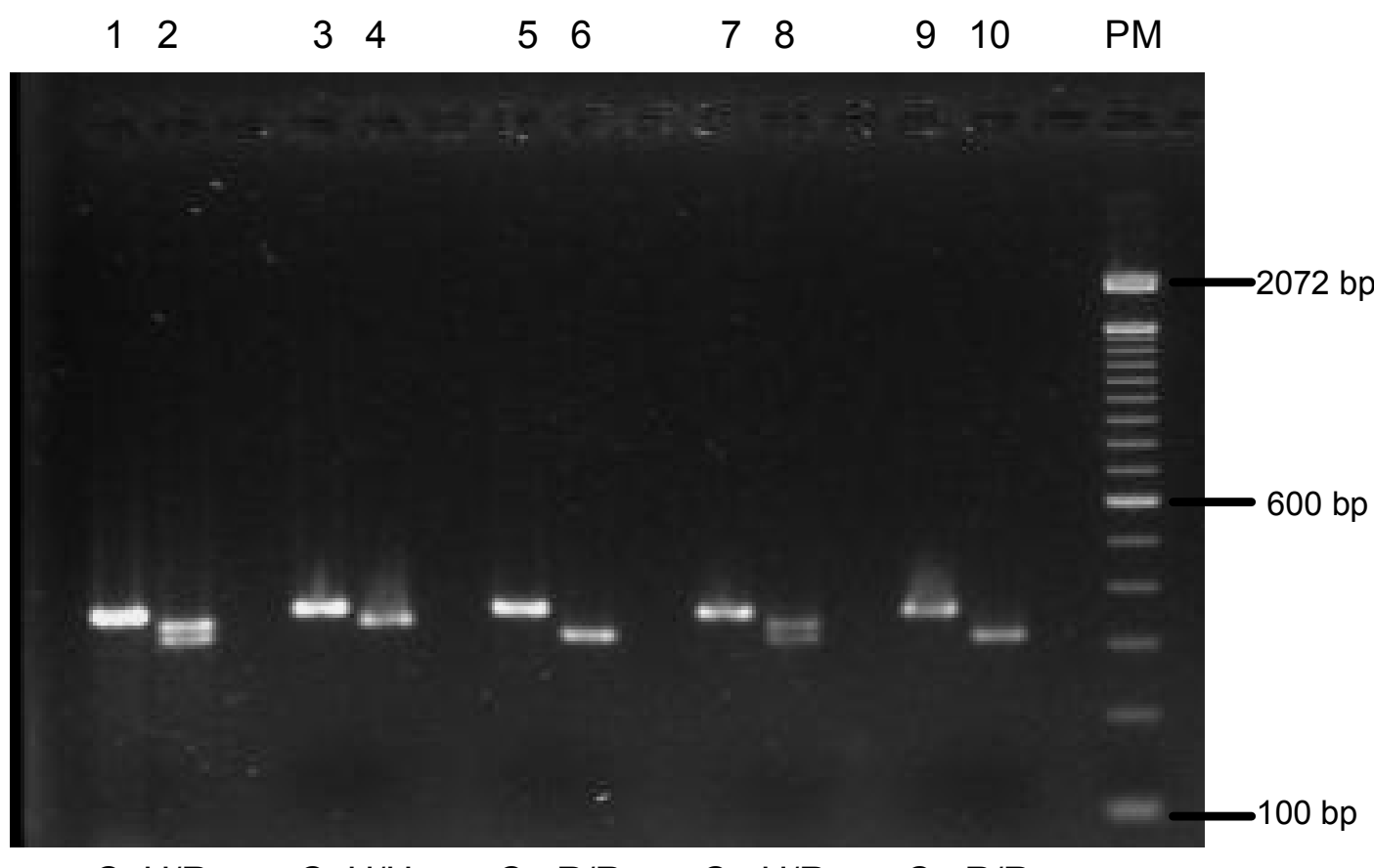
C $\mathrm{H} / \mathrm{R}$
$\mathrm{C} \mathrm{H} / \mathrm{H}$
C R/R
C $\mathrm{H} / \mathrm{R}$
C $R / R$

Fig.16. Eletroforese em gel de agarose a 3\% corado com brometo de etídio contendo os produtos de amplificação e da digestão do DNA com a enzima Bsh1236I (FnuDII). Linhas 2 e 8 representam amostras $(H / R)$, linha 4 representa amostra $(H / H)$ e as linhas 6 e 10 representam amostras $(R / R)$, digeridas com a enzima de restrição. As linhas 1, 3, 5, 7 e 9 (C) representam o produto de PCR sem digestão com a enzima de restrição. Abreviação: PM: padrão de tamanho molecular (100bp DNA Ladder). 


\section{DISCUSSÃO}


Em geral, a aquisição de imunidade na malária é lenta e para ser mantida requer a exposição a variantes antigênicas múltiplas dos plasmódios e a maturação do sistema imune. Com a idade diminui a incidência de mortalidade e morbidade e aumentam os níveis de anticorpos. Portanto, após várias infecções, pode-se observar em nível populacional, o aumento da prevalência de anticorpos a antígenos específicos e em nível individual, o reconhecimento de maior número de variantes de um antígeno em particular (DAY \& MARSH, 1991; BAIRD, 1995).

Durante muito tempo, os estudos da resposta imune humoral na malária se concentraram na avaliação da especificidade antigênica da resposta, mas muitas evidências de que a imunidade protetora estaria associada à mudança de classes e subclasses dos anticorpos mostraram a importância de se considerar à qualidade dos anticorpos produzidos, que envolve a afinidade da porção $F_{a b}$ pelo antígeno e a natureza da região $F_{c}$ que determina a função do anticorpo.

No nosso trabalho, avaliamos a resposta imune humoral de indivíduos naturalmente expostos à malária, de diferentes regiões do Brasil, a antígenos somáticos de $P$. falciparum. Em áreas de transmissão instável, como nas regiões endêmicas do Brasil, é mais difícil a associação da resposta humoral com proteção pela dificuldade em se encontrar grupos populacionais protegidos. Assim, associamos os resultados dos anticorpos com infecção patente por plasmódios, a exposição prévia à malária estratificada, em três grupos (mais de 5 malárias anteriores, 1 a 5 malárias 
anteriores e primo-infectados) e diferentes formas clínicas da malária (malária complicada, não complicada e assintomática).

Inicialmente, foram padronizadas técnicas imunoenzimáticas para a pesquisa de diferentes classes e subclasses (lgG1, $\lg G 2, \lg G 3, \lg G 4, \lg A$ e $\operatorname{lgE})$ de imunoglobulinas específicas para formas eritrocíticas de $P$. falciparum. Também foi otimizado o ELISA para pesquisa de anticorpos da classe IgM.

Os anticorpos conjugados à biotina usados no ELISA para detecção das subclasses de lgG foram testados contra mielomas de cada subclasse e os resultados mostraram boa especificidade (anexo I), o que nos assegurou confiabilidade nos resultados obtidos.

A diluição dos soros a $1 / 50$ foi a escolhida para as subclasses $\lg G 1$, lgG2 e lgG3 por ser a menor diluição que permitia clara distinção entre as amostras positivas das negativas. Para a detecção de anticorpos IgG4, que estão presentes em concentrações muito baixas no soro, a diluição de soros escolhida foi de $1 / 5$.

Para a pesquisa de anticorpos IgE foi necessária a absorção prévia dos anticorpos IgG com o reagente RF-Absorbent, que consiste de um anticorpo anti-IgG humana. Após a absorção o soro resultante apresenta nenhuma ou pouca concentração de $\lg G$, o que diminui a probabilidade de falsos resultados negativos pela competição de altos níveis de $\lg G$ com IgE ou de falsos resultados positivos por possível reação cruzada de anticorpos lgG com o conjugado anti-IgE humana marcada com biotina. Após a absorção, o soro fica diluído a 1/40. Para a pesquisa dos anticorpos $\lg G$ e $\lg M$ os soros 
foram diluídos a 1/100 e para os anticorpos IgA os soros foram diluídos a $1 / 25$.

Algumas amostras de soro de indivíduos com outras patologias foram positivas para determinadas classes e subclasses de anticorpos. As amostras positivas apresentaram sempre índices de reatividade baixos, muito próximos ao limiar considerado. Esses resultados podem ser devidos a reações inespecíficas, como auto-anticorpos das amostras de soro de indivíduos com doenças auto-imunes (FAN positivas, FR ou PCR) reagindo com componentes celulares das hemácias; ou devido a reações cruzadas, como a reatividade de amostras de soro de indivíduos com Doença de Chagas, Leishmaniose Cutânea, Toxoplasmose ou Sífilis. Ainda não podemos excluir a possibilidade de algumas amostras de soro serem realmente positivas para anticorpos anti- $P$. falciparum, visto que não conhecemos a história epidemiológica de cada doador.

Após a padronização dos testes, as amostras de soro de indivíduos de área endêmica foram testadas para todas as classes e subclasses de anticorpos. A casuística estudada consistiu de 233 indivíduos infectados por plasmódios diagnosticados pela gota espessa e/ou $\mathrm{QBC}^{\circledR}$ e apenas 37 indivíduos não infectados.

Os níveis de anticorpos IgG, determinados em índice de reatividade (IR), e $\lg G 1$, $\lg G 2$, IgG3, em concentração $(\mu \mathrm{g} / \mathrm{mL})$, foram maiores entre os indivíduos não infectados do que nos indivíduos infectados.Para a subclasse lgG4, verificamos maior nível entre os infectados. 
A freqüência de positividade e os níveis dos anticorpos $\lg G, \lg G 1, \lg G 2$ e IgG3 foram maiores nos grupos de indivíduos com maior número de episódios anteriores de malária, sendo que as concentrações desses anticorpos apresentaram correlação positiva significante com o número de malárias anteriores. A idade dos indivíduos correlacionou-se positivamente com significância com os anticorpos lgG, lgG1 e lgG2.

Considerando que o desenvolvimento de imunidade protetora depende do grau de exposição prévia, as correlações positivas com variáveis preditoras de exposição à malária sugerem o possível envolvimento dessas classes de anticorpos na proteção. Estas observações podem também explicar o fato de que apesar da grande maioria dos indivíduos estudados relatarem muitos episódios anteriores de malária (em média, 10), os níveis de lgG, lgG1, lgG2 e lgG3 foram maiores nos indivíduos não infectados do que nos infectados. Provavelmente os indivíduos não infectados estariam mais protegidos de novas infecções.

Também o papel protetor das subclasses pode ser evidenciado pelos maiores níveis encontrados nos indivíduos com malária não complicada e assintomática, quando comparados aos indivíduos com malária complicada.

Nossos resultados corroboram os de outros autores que mostraram uma relação entre anticorpos citofílicos, lgG1 e lgG3, com formas não graves da doença. Vários estudos mostraram que anticorpos lgG1 e lgG3 específicos seriam protetores na malária, enquanto anticorpos lgG4 seriam não protetores (BOUHAROUN-TAYOUN \& DRUILHE, 1992; DUBOIS et al, 1993; 
RZEPCZYK et al, 1997; TAYLOR et al, 1998; TANGTEERAWATANA et al, 2001).

Em indivíduos naturalmente imunes, anticorpos lgG1 e lgG3 anti$\mathrm{MSPf}_{19}$ evoluíram com as estações do ano dependendo, da carga parasitária e a produção específica de $\lg$ 1 1 versus $\lg G 3$ foi regulada independentemente. Para explicar as diferenças na regulação dos diferentes isotipos de anticorpos, especula-se se a evolução dos anticorpos lgG1 e lgG3 seja decorrente do catabolismo e/ ou da utilização desses anticorpos (DIALLO et al, 2002).

Um estudo realizado com indivíduos com malária grave em Dakar, no oeste da África, não encontrou anticorpos lgG3 em indivíduos que evoluíram para a fatalidade; por outro lado, anticorpos $\lg G 3$, em baixos níveis foram encontrados nos indivíduos que evoluíram bem, mostrando que de alguma maneira estes anticorpos estariam contribuindo para a ausência de mortalidade (SARTHOU et al, 1997).

Apesar dos anticorpos IgG2 não participarem dos mecanismos efetores de opsonização, fagocitose e $A D C I$ por não se ligarem aos receptores $F c \gamma R$, principalmente ao FcyRIIA, um receptor encontrado em células e envolvido na ativação da produção de TNF- $\alpha$ e conseqüente morte do parasita, nossos resultados mostraram predominância de anticorpos lgG2 em indivíduos com formas não complicadas de malária. Deloron et al. (1997) já haviam mostrado uma associação entre altos níveis de lgG2 e baixo risco de se adquirir infecção por $P$. falciparum. Também Aucan et al. (2000) 
encontraram associação entre altos níveis de anticorpos $\lg G 2$ para epitopos de RESA e MSP2 e baixo risco de infecção.

O papel protetor de anticorpos IgG2 na malária em determinadas populações tem sido explicado pela ocorrência de um polimorfismo no gene do receptor FcyRIIA (AUCAN et al, 2000). O polimorfismo H131 que é uma mudança de arginina $(R)$ para histidina $(H)$ na posição 131, permite a ligação da fração $F_{c}$ de lgG2 ao receptor, conferindo assim capacidade citofílica aos anticorpos IgG2 (WARMERDAM et al, 1991).

Como nossos resultados também sugeriram uma ação citofílica dos anticorpos lgG2, investigamos a existência do polimorfismo H131 na parte da nossa população de que dispunhamos. Infelizmente não foi possível a investigação do polimorfismo na maioria da população com formas complicadas da malária, por não dispormos de sangue total para extração de DNA. Desta forma o polimorfismo H131 foi investigado em 53 amostras de DNA de indivíduos infectados sintomáticos e assintomáticos. A freqüência do alelo H131 nesta população foi $67,9 \%$, sendo $22,6 \% \mathrm{H} / \mathrm{H}$ e $45,3 \% \mathrm{H} / \mathrm{R}$. O aminoácido arginina na posição (R/R) foi encontrado em $32,1 \%$ dos indivíduos. Encontramos que tanto a freqüência de positivos como os níveis dos anticorpos IgG2 foram significantemente maiores nos indivíduos assintomáticos $(76,9 \%)$ do que nos sintomáticos $(39,1 \%)$. Entre os indivíduos que carregam o polimorfismo $\mathrm{H} 131$ os níveis de lgG2 foram muito maiores nos assintomáticos $(78,7 \mu \mathrm{g} / \mathrm{mL})$ dos que nos sintomáticos $(3,35$ $\mu \mathrm{g} / \mathrm{mL})$. 
Aucan et al. (2000) também encontraram uma freqüência aproximada de $70 \%$ do polimorfismo H131 na população e os níveis de lgG2 se correlacionaram com baixo risco de infecção por $P$. falciparum. Os altos níveis de IgG2 que encontramos nos indivíduos assintomáticos portadores do polimorfismo sugerem a participação de lgG2 como anticorpo citofílico na nossa população, cuja freqüência do polimorfismo H131 também foi alta.

Os resultados obtidos com os anticorpos IgG4 também estão de acordo com os da literatura. Os níveis de lgG4 apresentaram correlação negativa com o número de malárias anteriores, e a freqüência de positividade e os níveis de IgG4 foram maiores nos grupos de indivíduos com poucos episódios anteriores de malária e nos indivíduos com malária complicada.

A associação de anticorpos lgG4 específicos na malária com ausência de proteção foi observada por outros autores (ARIBOT et al, 1996; AUCAN et al, 2000). IgG4 inibe in vitro a ação de anticorpos citofílicos, lgG1 e lgG3, responsáveis por mediarem a opsonização de eritrócitos infectados (GROUX \& GYSIN, 1990). Soe-Soe et al. (2004) observaram que os níveis dos anticorpos lgG4 contra diferentes regiões de GLURP (Proteína rica em glutamato), (R0 e R1) se associaram negativamente com proteção clínica. $\mathrm{Na}$ infecção por S. mansoni, lgG4 bloqueia mecanismos protetores mediados por anticorpos e também inibe a morte do parasita por eosinófilos (KHALIFE et al, 1989; RIHET et al, 1992).

Aucan et al. (2000) observaram que a correlação positiva de lgG4 com o risco de infecção foi mais forte quando os níveis de lgG2 eram baixos sugerindo que IgG4 estaria neutralizando a citoxicidade celular mediada por 
monócitos ou outras células efetoras dependentes de lgG2. Assim IgG4 teria um papel bloqueador da ação protetora de $\lg G 2$.

Outro aspecto essencial da resposta imune humoral é a afinidade dos anticorpos que pode refletir a qualidade dos anticorpos envolvidos em proteção ou em diferentes fases da doença.

A afinidade funcional ou avidez é a medida da força entre o antígeno e o anticorpo. A avidez de determinadas classes de anticorpos aumenta com o tempo, após estímulos antigênicos e em diferentes infecções, como conseqüência da maturação da resposta imune (ABBAS et al, 2000). Nos estágios iniciais de uma infecção, quando presumivelmente existem grandes quantidades de antígeno presente, células B com receptores de membrana de diferentes graus de avidez são estimuladas e o resultado total é uma resposta humoral específica com anticorpos de grande variedade de avidez. Com o tempo, o nível de antígenos cai e o remanescente estimula preferencialmente células B com receptores altamente específicos e de alta avidez, levando à produção de clones de células produtoras de anticorpos de maior avidez.

A avidez de anticorpos produzidos em resposta a um estímulo antigênico parece ser dependente da natureza desse estímulo, de fatores genéticos, da eficiência dos macrófagos em processarem o antígeno para apresentarem às células imunocompetentes, da presença de antígenos circulantes e anticorpos circulantes e da presença de células T auxiliares.

A medida de avidez tem sido amplamente utilizada no diagnóstico de infecções, como na rubéola, citomegalovírus, herpesvírus, varicela-zoster 
(revisado em WOZICOVA, 2004). Na toxoplasmose, a determinação da avidez de anticorpos IgG específicos tem permitido diferenciar fase aguda de fase pregressa (CAMARGO, 1991).

Na malária, Ferreira et al. (1996) estudaram a avidez de anticorpos anti-formas eritrocitárias de $P$. falciparum, naturalmente adquiridos, em população de área endêmica, com transmissão estável, na África, e transmissão instável, na Amazônia Brasileira. Eles observaram que anticorpos de alta avidez, particularmente da subclasse lgG1, predominaram na resposta humoral anti- $P$. falciparum desenvolvida por africanos clinicamente imunes. Os pacientes da Amazônia, produziram anticorpos de baixa avidez durante a fase aguda, que poderia ser explicado pela ativação policlonal de células $B$. Dois meses após a quimioterapia, a proporção de anticorpos IgG de alta avidez anti- $P$. falciparum aumentou significantemente, mas a concentração de anticorpos citofílicos diminuiu. Eles postularam que anticorpos de alta qualidade anti- $P$. falciparum seriam produzidos inicialmente durante o crescimento intra-eritrocítico do parasita, e agiriam enquanto as parasitemias ainda eram baixas, sendo mais efetivos contra a severidade da doença.

Nossos resultados mostraram predomínio de anticorpos lgG, IgG1, lgG2 e IgG3 de alta avidez e anticorpos IgG4 de baixa avidez entre os indivíduos não infectados e o inverso foi observado entre os indivíduos infectados. Nos indivíduos não infectados os anticorpos de alta avidez provavelmente estão controlando a reinfecção rapidamente e desempenhando um papel protetor eficaz contra o parasita. Enquanto nos indivíduos infectados a produção de 
anticorpos de baixa avidez seja é devida à ativação policlonal de células B, como verificado por Ferreira et al. (1996).

Anticorpos de baixa avidez de todas os isótipos predominaram nos indivíduos com malária complicada, o que pode ser um reflexo do predomínio, neste grupo, de indivíduos com poucos episódios anteriores de malária. Mas, também predomínio de anticorpos de baixa avidez poderia estar associado ao não controle da infecção com uma expressão de imunodeficiência (FERREIRA et al, 1996).

Anticorpos lgG3 em geral foram de baixa avidez, independentemente da forma clínica da malária, o que pode sugerir que estes anticorpos sejam, preferencialmente induzidos contra novas variantes dos antígenos polimórficos do estágio eritrocítico de $P$. falciparum. Também a baixa avidez predominante nos anticorpos lgG3 poderia ser explicada pela curta meiavida que apresentam ( 7-8 dias), comparada à meia-vida das outras subclasses IgG1 lgG2 e IgG4 ( 23 dias) (CALICH \& VAZ, 2001; WINKLER et al, 1998).

As freqüências de positividade e os níveis dos anticorpos $\lg E$ não diferiram entre indivíduos infectados e não infectados. A positividade para anticorpos $\lg \mathrm{E}$ foi mais freqüente nos indivíduos com mais de cinco malárias anteriores, apesar dos níveis de anticorpos IgE terem sido maiores no grupo de primo-infectados. Os níveis de lgE foram maiores nos indivíduos com malária complicada.

Infecção experimental em camundongos com $P$. chabaudi chabaudi induz elevação dos níveis de IgE somente após repetidas infecções 
indicando que a reexposição e/ ou infecção crônica é de grande importância (HELMBY et al, 1996); este fato pode justificar o fato da maior freqüência de a positividade ter sido observada nos indivíduos que relatavam mais de cinco episódios anteriores de malária.

Anticorpos lgE anti-plasmodiais podem ser protetores, mas também devem contribuir para a gravidade da doença. Correlações observadas entre os níveis de IgE com a idade suportam a hipótese de que teriam um papel protetor contra malária (DESOWITZ et al, 1993; MAENO et al, 1993). Mais recentemente foram observadas altas concentrações de $\lg E$ em indivíduos com malária grave não comatosos quando comparados com indivíduos comatosos, sugerindo um papel protetor destes anticorpos (CALISSANO et al, 2003). O papel protetor de IgE é bem estabelecido na esquistossomose (JARRET \& MILLER, 1982; ALLEN, 1993; CAPRON \& CAPRON 1994; MILLER, 1996).

Outros trabalhos sugerem que os anticorpos $\lg E$ poderiam estar envolvidos na imunopatogênese da malária. Perlmann et al. (1994) observaram um aumento nos níveis de lgE em indivíduos com malária cerebral quando comparados com malária não complicada.

Um fator essencial da patogênese da malária falciparum é a citoaderência de eritrócitos infectados ao endotélio das vênulas póscapilares, levando à obstrução do fluxo sangüíneo e várias respostas inflamatórias. Isso envolve o recrutamento de monócitos, ativação endotelial e a liberação de citocinas, tal como fator de necrose tumoral- $\alpha$ (TNF- $\alpha$ ) (BERENDT et al, 1989). Embora TNF- $\alpha$ possa proteger contra os parasitas 
(CLARK et al, 1991; MILLER et al, 1994), sua superprodução local causa dano tecidual e também a sua concentração elevada no sangue está correlacionada à morbidade e mortalidade na malária grave (GRAU et al, 1989; KWIATKOWSKI et al, 1990).

A principal fonte de TNF- $\alpha$ são monócitos ativados pelas "toxinas" derivadas do parasita contendo moléculas de glicosilfosfatidil inositol (GPI) (JAKOBSEN et al, 1995; KWIATKOWSKI, 1995). No entanto, imunocomplexos de $\lg E$ com antígeno ou com IgG anti-lgE podem induzir a expressão de receptores $\mathrm{Fc}_{\boldsymbol{c} \varepsilon}$ em monócitos e a interação com estes receptores leva à ativação celular e à liberação de TNF- $\alpha$. Isto foi observado in vitro quando células induziram a liberação de TNF- $\alpha$, mas dependentemente de IgE (ELGHAZALI et al, 1997). In vivo a superprodução local de TNF- $\alpha$ em indivíduos com malária cerebral, pode ser induzida em monócitos pela reação com depósitos de imunocomplexos contendo antígeno e anticorpos IgE (MAENO et al, 2000). Imunocomplexos de IgE ligados a receptores CD23 (receptor de baixa afinidade de IgE -FcعII) podem levar à ativação da óxido nítrico sintase (NOS) e resultar na produção de óxido nítrico (NO) (DUGAS et al, 1995). No entanto, TNF- $\alpha$ e outras citocinas podem também induzir diretamente a liberação de NO (DING et al, 1988; CLARK et al, 1991). Ghigo et al. (1995) demonstraram que eritrócitos infectados podem gerar por si só grandes quantidades de NO, provavelmente produzindo um fator solúvel que induza NOS nas células endoteliais. Estes resultados sugerem que mecanismos dependentes e 
independentes de IgE podem estar envolvidos na indução de TNF- $\alpha$ e NO nos microvasos, na malária cerebral.

Os maiores níveis de $\lg E$ específicos encontrados no grupo de indivíduos com malária complicada, observados no nosso trabalho, sugerem e favorecem mais a participação desses na patogênese da doença do que em proteção. Os níveis de IgE total também estavam bem aumentados na nossa população, como tem sido observado em populações de áreas endêmicas (PERLMANN et al,1994).

As freqüências de positividade e os níveis dos anticorpos $\lg M$ não diferiram entre indivíduos infectados e não infectados, mas foram mais freqüentes nos indivíduos primo-infectados dos que nos que relataram de 1 a 5 malárias ou mais de 5 malárias. Os níveis de IgM diminuíram com número de malárias anteriores. Maior freqüência de anticorpos $\operatorname{lgM}$ em indivíduos primo-infectados era esperado, pois IgM é a primeira classe de anticorpos produzida numa resposta humoral primária. Este fato também deve ter contribuído para o predomínio de $\lg \mathrm{M}$ em indivíduos com formas complicadas de malária, pois entre estes estavam a maioria dos primoinfectados.

As freqüências de positividade e os níveis dos anticorpos $\lg A$ também não diferiram entre indivíduos infectados e não infectados. A freqüência de anticorpos lgA não diferiu com o número de malárias anteriores, mas os níveis de $\lg \mathrm{A}$ diminuíram com o número de malárias anteriores. Estes resultados estão de acordo com resultados anteriores do nosso grupo quando foi observado predomínio de anticorpos $\lg A$ em primo-infectados. 
(ÁVILA et al, 1993; ÁVILA et al, 1999). Nenhuma outra relação dos anticorpos IgA com variáveis preditoras de exposição ou proteção foi observada.

A visualização do perfil da resposta humoral de cada indivíduo estudado (figura 15) reforça as observações da predominância de resposta de anticorpos lgG1, IgG2 e lgG3 nos indivíduos assintomáticos e com malária não complicada e de $\operatorname{lgG} 4$, IgE e $\operatorname{lgM}$ nos indivíduos com malária complicada.

Como as diferentes classes e subclasses de anticorpos reagem com os mesmos epitopos, mas aparentemente, podem afetar o curso da infecção de modo diferente, estabelecemos interações entre os anticorpos calculando razões entre os seus níveis. As interações podem ser um modo apropriado para estimar a atividade de anticorpos.

Observamos que nos indivíduos assintomáticos e com malária não complicada predominaram as interações dos anticorpos $\lg \mathrm{G} 1$, IgG2 e $\lg G 3$, enquanto nos indivíduos com malária complicada predominaram as interações entre $\lg G 4$ e IgE. Maiores razões dos níveis de $\lg G 2$ em relação a lgG4 predominam nos indivíduos assintomáticos e com malária não complicada, como observado por Aucan et al. (2000). A razão IgE/lgG foi significantemente maior nos indivíduos com malária complicada do que nos que não apresentavam complicações clínicas, o que pode sugerir que anticorpos IgG e IgE reativos contra os mesmos epitopos poderiam estar exercendo funções opostas durante a infecção. Assim as relações entre 
anticorpos $\lg G / \lg E$, IgG1-lgG2-lgG3/lgG4, IgG2/lgG4, IgG4-lgE/lgG2 podem refletir o equilíbrio entre a patogenicidade e a proteção na malária.

Calissano et al. (2003) observaram baixos níveis de anticorpos lgG antiP. falciparum em indivíduos em coma, isto poderia ser devido a uma fraca resposta humoral ou grande quantidade de anticorpos poderiam estar ligados aos parasitas seqüestrados. Uma explicação adicional, mas não exclusiva nas diferentes concentrações de anticorpos, reflete outros fatores genéticos que estão contribuindo para a proteção e/ ou patogenicidade da doença.

A medida de anticorpos em fluidos corpóreos reflete uma situação estática, ou seja, são medidos os anticorpos que estão presentes neste fluido no tempo da amostragem. Poucos ou ausentes anticorpos de uma ou mais subclasses sugerem ou que estas moléculas não estão sendo produzidas ou que estão sendo utilizadas. Os níveis de anticorpos detectáveis no plasma ou soro de indivíduos imunes a $P$. falciparum provavelmente resultem do equilíbrio entre a produção e o uso de anticorpos específicos contra o parasita (DIALLO et al, 2002).

Como na infecção por $P$. falciparum a imunidade nunca é completamente estéril, é plausível que haja uma produção contínua de anticorpos. Esses anticorpos são produzidos em quantidades excessivas ou decaem ou ocorre um clareamento a níveis indetectáveis. Isto tem pelo menos duas conseqüências: (a). anticorpos específicos são produzidos, provavelmente em excesso conjuntamente com anticorpos de especificidades irrelevantes que poderiam estar envolvidos na "decepção" 
imune, um fenômeno geralmente observado em infecções parasitárias; (b). células B de memória específicas e diferenciadas são produzidas com especificidade para os antígenos mais abundantes do parasita com mudanças do isotipo de novo em resposta a novas variantes antigênicas (GARRAUD et al, 2003).

A seleção do isotipo e a maturação da afinidade de um anticorpo são conseqüências de um processo de diferenciação de células B que ocorrem nos centros germinativos dos linfonodos em um indivíduo imunizado. Embora, a afinidade funcional ou avidez dependa do antígeno e da seleção de clones de células que produzam anticorpos com melhor cinética de ligação ao epitopo, a seleção de isotipos (classe/subclasse) é um fenômeno complexo que resulta de múltiplos mecanismos, muitos dos quais não são ainda bem compreendidos (MANIS et al, 2002).

Entre os mecanismos mais importantes que levam à mudança do isotipo da cadeia pesada estão a intensidade e a duração da ligação do receptor da célula B com o epitopo e a natureza dos sinais co-estimulatórios que acontecem simultaneamente à ligação. As citocinas predominantes no contexto da resposta a um determinado antígeno é que vão fornecer ou aumentar esses sinais co-estimulatórios para as células $\mathrm{B}$, agindo no núcleo, ou diretamente na cadeia pesada da imunoglobulina ou ainda regulando a maturação da afinidade (GARRAUD \& NUTMAN, 1996). Citocinas produzidas por células $\mathrm{CD}^{+}$Th1, como IFN- $\gamma$, IL-2, IL-12 induzem a produção dos anticorpos citofilicos que participam de mecanismos efetores celulares dependentes de anticorpos. Citocinas produzidas por células $\mathrm{CD} 4^{+}$ 
Th2, como IL-4, IL-5, IL-10, induzem a produção de anticorpos neutralizantes e ainda bloqueadores dos mecanismos induzidos por Th1.

Winkler et al. (1998) mostraram mudança de resposta Th2 preferencial em malária aguda não tratada para uma resposta regulada por Th1, sendo que IFN- $\gamma$ foi essencial para a resolução da parasitemia e IL-10 pareceu ser a molécula chave no controle de respostas inflamatórias, que quando exageradas, podem levar a dano tecidual mais do que ao clareamento da parasitemia.

Provavelmente, o desenvolvimento gradual de imunidade protetora na malária, de fato, corresponda a uma modificação progressiva na regulação da resposta imune e não, como se pensou por muito tempo, o lento desenvolvimento de uma resposta ou a moléculas pobremente imunogênicas ou altamente polimórficas. Dados de "Immunoblotting" e ADCI sugerem que o hospedeiro exposto uma vez, ou um número limitado de vezes, à malária pode desenvolver altos níveis de anticorpos a antígenos que levam a mecanismos protetores, embora estes mecanismos não sejam funcionais. Ao contrário, a aquisição de um estado de resistência parece correlacionar-se com a habilidade de desenvolver anticorpos de um isotipo próprio, na maioria $\lg G 1$ e $\lg G 3$, e reduzir a proporção de isótipos não citofílicos (IgG4 e IgM) da mesma especificidade que bloqueiem mecanismos efetores (BOUHAROUN-TAYOUN \& DRUILHE, 1992).

Nossos resultados mostraram que, mesmo em populações de regiões com transmissão de malária instável, podemos observar o desenvolvimento de um certo grau de imunidade protetora, quando anticorpos apropriados 
são produzidos, mesmo com análise sendo feita com antígenos totais de formas eritrocitárias. Estudos posteriores deverão ser feitos, nessa mesma população, com antígenos específicos e candidatos a compor uma vacina com múltiplos epitopos para malária, pois é muito importante avaliar a capacidade do sistema imune de selecionar os mecanismos apropriados, por ex. produção preferencial de $\operatorname{lgG} 1$ e/ou lgG3 a antígenos particulares que levem a uma resposta protetora. 
VI. CONCLUSÕES 
1. Foram padronizadas técnicas imunoenzimáticas para a pesquisa de IgG1, IgG2, IgG3, IgG4, IgE, IgA e IgM contra formas eritrocitárias de P.falciparum.

2. Maiores níveis de anticorpos $\lg G$, $\lg G 1$, $\lg G 2$ e $\lg G 3$ foram observados nos indivíduos naturalmente expostos à malária não infectados do que nos indivíduos infectados e o oposto foi observado para lgG4.

3. Os níveis de anticorpos $\lg$, $\lg G 1$, $\lg G 2, \lg G 3$ apresentaram correlação positiva com o número de episódios anteriores de malária relatados pelos indivíduos naturalmente expostos, enquanto os anticorpos lgG4 apresentaram correlação negativa.

4. Os níveis de anticorpos IgG, IgG1 e IgG2 e os níveis de avidez de lgG e IgG1 apresentaram correlação positiva com a idade dos indivíduos naturalmente expostos à malária. 
5. Indivíduos naturalmente expostos à malária com melhor resposta à infecção, ou seja, sem complicações clínicas de malária ou assintomáticos, apresentaram resposta imune humoral específica com predomínio dos anticorpos lgG, IgG1, IgG2 de alta avidez e IgG3 de baixa avidez. Indivíduos naturalmente expostos à malária com complicações clínicas por malária apresentaram resposta imune humoral específica com predomínio dos anticorpos lgG4, IgE e IgM.

6. Altos níveis de anticorpos lgG2 foram encontrados nos indivíduos assintomáticos portadores do polimorfismo $\mathrm{H} 131$ do gene do receptor FcyRIIA, que confere ação citofílica aos anticorpos lgG2 e pode justificar a associação de IgG2 com proteção observada na população estudada.

7. Os resultados mostraram que mesmo em populações de regiões com transmissão de malária instável pode ser observado o desenvolvimento de um certo grau de imunidade protetora quando anticorpos apropriados são produzidos, ou seja, das classes lgG1, IgG2 e IgG3. 
VII. ANEXOS 


\section{Anexo I - Padronização do ELISA - subclasses de IgG}

Densidades ópticas obtidas no ELISA com diferentes diluições dos conjugados anti-lgG1, anti-lgG2, anti-lgG3 e anti-lgG4 humano marcado com biotina e diferentes concentrações de mieloma purificado das subclasses lgG1, lgG2, IgG3 e lgG4. [ ] concentração em ng/mL.

\begin{tabular}{|c|c|c|c|c|c|}
\hline \multirow{3}{*}{$\begin{array}{l}\text { Conjugado } \\
\text { Anti-humano } \\
\text { Marcado com } \\
\text { biotina } \\
\text { IgG1 }\end{array}$} & \multirow[b]{2}{*}{ diluições } & \multicolumn{4}{|c|}{ Mieloma IgG1 [] ng/mL } \\
\hline & & 5000 & 1000 & 200 & 40 \\
\hline & $1 / 1000$ & 1,079 & 1,132 & 0,899 & 0,257 \\
\hline \multirow{3}{*}{$\lg G 2$} & $1 / 2000$ & 1,176 & 1,069 & 0,738 & 0,216 \\
\hline & $1 / 500$ & 0,029 & 0,063 & 0,041 & 0,033 \\
\hline & $1 / 1000$ & 0,013 & 0,081 & 0,073 & 0,075 \\
\hline \multirow[t]{2}{*}{$\lg G 3$} & $1 / 500$ & 0,025 & 0,087 & 0,087 & 0,039 \\
\hline & $1 / 1000$ & $-0,034$ & $-0,009$ & $-0,030$ & $-0,022$ \\
\hline \multirow[t]{2}{*}{$\operatorname{lgG} 4$} & $1 / 500$ & $-0,016$ & $-0,004$ & $-0,016$ & $-0,022$ \\
\hline & $1 / 1000$ & $-0,057$ & 0,000 & 0,025 & 0,005 \\
\hline \multirow{4}{*}{$\begin{array}{c}\text { Conjugado } \\
\text { Anti-humano } \\
\text { Marcado com } \\
\text { biotina } \\
\text { IgG1 }\end{array}$} & & \multicolumn{4}{|c|}{ Mieloma IgG2 [ ] ng/mL } \\
\hline & diluições & 5000 & 1000 & 200 & 40 \\
\hline & $1 / 1000$ & 0,344 & 0,106 & 0,011 & 0,001 \\
\hline & $1 / 2000$ & 0,268 & 0,066 & 0,013 & 0,001 \\
\hline \multirow[t]{2}{*}{$\lg G 2$} & $1 / 500$ & 1,010 & 0,704 & 0,221 & 0,026 \\
\hline & $1 / 1000$ & 1,035 & 0,585 & 0,131 & 0,018 \\
\hline \multirow[t]{2}{*}{$\lg G 3$} & $1 / 500$ & 0,138 & 0,056 & 0,007 & 0,009 \\
\hline & $1 / 1000$ & 0,055 & 0,037 & $-0,005$ & $-0,012$ \\
\hline \multirow[t]{2}{*}{$\operatorname{lgG} 4$} & $1 / 500$ & 0,033 & 0,013 & $-0,003$ & $-0,004$ \\
\hline & $1 / 1000$ & 0,019 & 0,005 & $-0,006$ & $-0,010$ \\
\hline
\end{tabular}


Anexo I - Padronização do ELISA-subclasses de IgG (cont.)

\begin{tabular}{|c|c|c|c|c|c|}
\hline \multirow{3}{*}{$\begin{array}{l}\text { Conjugado } \\
\text { Anti-humano } \\
\text { Marcado com } \\
\text { biotina } \\
\text { IgG1 }\end{array}$} & \multirow[b]{2}{*}{ diluições } & \multicolumn{4}{|c|}{ Mieloma lgG3 [ ] ng/mL } \\
\hline & & 5000 & 1000 & 200 & 40 \\
\hline & $1 / 1000$ & 0,123 & 0,048 & 0,015 & 0,006 \\
\hline \multirow{3}{*}{$\operatorname{lgG} 2$} & $1 / 2000$ & 0,062 & 0,032 & 0,022 & 0,017 \\
\hline & $1 / 500$ & 0,034 & 0,051 & $-0,010$ & $-0,005$ \\
\hline & $1 / 1000$ & $-0,005$ & 0,030 & $-0,028$ & $-0,033$ \\
\hline \multirow[t]{2}{*}{$\operatorname{lgG} 3$} & $1 / 500$ & 1,240 & 0,966 & 0,044 & 0,215 \\
\hline & $1 / 1000$ & 1,084 & 0,0857 & 0,371 & 0,097 \\
\hline \multirow[t]{2}{*}{$\operatorname{lgG} 4$} & $1 / 500$ & 0,043 & 0,007 & 0,003 & 0,006 \\
\hline & $1 / 1000$ & $-0,003$ & 0,004 & 0,004 & 0,025 \\
\hline \multirow{4}{*}{$\begin{array}{l}\text { Conjugado } \\
\text { Anti-humano } \\
\text { Marcado com } \\
\text { biotina } \\
\text { IgG1 }\end{array}$} & & \multicolumn{4}{|c|}{ Mieloma IgG4 [ ] ng/mL } \\
\hline & diluições & 5000 & 1000 & 200 & 40 \\
\hline & $1 / 1000$ & 0,123 & 0,022 & 0,004 & 0,037 \\
\hline & $1 / 2000$ & 0,062 & 0,022 & 0,004 & 0,018 \\
\hline \multirow[t]{2}{*}{$\lg G 2$} & $1 / 500$ & 0,023 & 0,007 & 0,003 & 0,006 \\
\hline & $1 / 1000$ & 0,011 & 0,002 & 0,003 & 0,003 \\
\hline \multirow[t]{2}{*}{$\lg G 3$} & $1 / 500$ & 0,059 & 0,029 & 0,007 & 0,002 \\
\hline & $1 / 1000$ & 0,038 & 0,018 & 0,003 & 0,003 \\
\hline \multirow[t]{2}{*}{$\operatorname{lgG} 4$} & $1 / 500$ & 0,994 & 0,948 & 0,403 & 0,069 \\
\hline & $1 / 1000$ & 0,992 & 0,899 & 0,393 & 0,046 \\
\hline
\end{tabular}




\section{Anexo II - Padronização do ELISA-IgE}

Titulação dos soros anti-lgE humana em ELISA com placas sensibilizadas com mieloma de IgE humana.

\begin{tabular}{|c|c|c|c|c|c|}
\hline \multirow[t]{2}{*}{ Soros anti-lgE humana } & \multicolumn{5}{|c|}{ Diluições do mieloma de $\operatorname{lgE}$} \\
\hline & $1 / 100$ & $1 / 500$ & $1 / 1000$ & $1 / 5000$ & branco \\
\hline soro de carneiro $(6 / 7 / 82)(A)$ & 1,111 & 1,628 & 1,209 & 1,152 & 0,169 \\
\hline soro de carneiro (Cappel) (B) & 2,145 & 2,009 & 2,241 & 1,309 & 0,748 \\
\hline $\begin{array}{l}\text { soro de cabra marcado com } \\
\text { peroxidase (Sigma Chem. Co. } \\
11 / 11 / 96)(C)\end{array}$ & 2,744 & 1,983 & 2,372 & 1,678 & 0,073 \\
\hline \multirow{2}{*}{$\begin{array}{l}\text { soro de cabra (específico para } \\
\text { cadeia } \varepsilon \text { ) marcado com peroxidase } \\
\text { (Sigma Chem. Co, lote 029H4887) } \\
\text { (D) }\end{array}$} & 2,284 & 2,164 & 2,165 & 2,243 & 0,087 \\
\hline & $1 / 100$ & $1 / 200$ & $1 / 400$ & $1 / 800$ & branco \\
\hline $\begin{array}{l}\text { soro de cabra (Sigma Chem Co., } \\
55,3 \mathrm{mg} / \mathrm{mL} \text { ) marcada com biotina } \\
(\mathrm{E})\end{array}$ & 2,119 & 2,332 & 2,201 & 1,928 & 0,162 \\
\hline
\end{tabular}




\section{Anexo III - Padronização do ELISA-IgM}

Média das densidades ópticas obtidas no ELISA com diferentes diluições dos soros controles positivos e soros negativos para anticorpos IgM antiformas eritrocitárias de $P$. falciparum e diferentes diluições dos conjugados e nas variáveis de bloqueio e armazenamento estudadas: A. leite desnatado a $5 \%$ em PBS (PBS-L) por 2 horas a $37^{\circ} \mathrm{C}$ e tratamento com solução estabilizante; B. PBS-L por 2 horas a $37^{\circ} \mathrm{C}$ e secagem direta das placas; C. PBS-L por 18 horas a $4^{\circ} \mathrm{C}$ e tratamento com solução estabilizante; D. PBS-L por 18 horas a $4^{\circ} \mathrm{C}$ e secagem direta das placas.

\begin{tabular}{|c|c|c|c|c|c|c|}
\hline \multicolumn{7}{|c|}{ ELISA - resultados } \\
\hline \multirow[t]{2}{*}{ Variável } & \multicolumn{2}{|c|}{ Soros } & \multicolumn{4}{|c|}{ Diluição do conjugado anti-IgM humana } \\
\hline & & diluição & $1 / 5.000$ & $1 / 10.000$ & $1 / 20.000$ & $1 / 30.000$ \\
\hline \multirow{7}{*}{ A } & & $1 / 25$ & 1,831 & 1,158 & 0,571 & 0,429 \\
\hline & positivos & $1 / 50$ & 1,719 & 0,954 & 0,462 & 0,374 \\
\hline & & $1 / 100$ & 1,477 & 0,800 & 0,359 & 0,281 \\
\hline & & $1 / 200$ & 1,204 & 0,659 & 0,290 & 0,249 \\
\hline & & $1 / 25$ & 0,505 & 0,249 & 0,111 & 0,089 \\
\hline & negativos & $1 / 50$ & 0,362 & 0,166 & 0,078 & 0,065 \\
\hline & & $1 / 100$ & 0,244 & 0,101 & 0,046 & 0,046 \\
\hline \multirow{7}{*}{ B } & & $1 / 25$ & 2,225 & 1,397 & 0,884 & \\
\hline & positivos & $1 / 50$ & 1,991 & 1,221 & 0,730 & \\
\hline & & $1 / 100$ & 1,790 & 1,041 & 0,616 & \\
\hline & & $1 / 200$ & 1,467 & 0,811 & 0,540 & \\
\hline & & $1 / 25$ & 0,857 & 0,446 & 0,225 & \\
\hline & negativos & $1 / 50$ & 0,549 & 0,295 & 0,154 & \\
\hline & & $1 / 100$ & 0,404 & 0,202 & 0,097 & \\
\hline \multirow{7}{*}{ C } & & $1 / 25$ & 1,808 & 1,038 & 0,498 & 0,347 \\
\hline & positivos & $1 / 50$ & 1,502 & 0,882 & 0,428 & 0,319 \\
\hline & & $1 / 100$ & 1,229 & 0,747 & 0,360 & 0,264 \\
\hline & & $1 / 200$ & 1,017 & 0,593 & 0,287 & 0,225 \\
\hline & & $1 / 25$ & 0,567 & 0,292 & 0,154 & 0,104 \\
\hline & negativos & $1 / 50$ & 0,387 & 0,200 & 0,114 & 0,076 \\
\hline & & $1 / 100$ & 0,269 & 0,140 & 0,060 & 0,057 \\
\hline \multirow{7}{*}{$D$} & & $1 / 25$ & 1,805 & 1,104 & 0,632 & 0,510 \\
\hline & positivos & $1 / 50$ & 1,607 & 0,920 & 0,541 & 0,411 \\
\hline & & $1 / 100$ & 1,379 & 0,791 & 0,438 & 0,355 \\
\hline & & $1 / 200$ & 1,176 & 0,667 & 0,377 & 0,294 \\
\hline & & $1 / 25$ & 0,623 & 0,339 & 0,184 & 0,145 \\
\hline & negativos & $1 / 50$ & 0,429 & 0,227 & 0,131 & 0,101 \\
\hline & & $1 / 100$ & 0,305 & 0,160 & 0,090 & 0,067 \\
\hline
\end{tabular}




\section{Anexo III - Padronização do ELISA-IgM (cont.)}

Densidades ópticas do soro limiar de reatividade artificialmente preparado pela diluição de "pool" de soros positivos para anticorpos lgM anti-formas eritrocitárias de $P$. falciparum em "pool" de soros negativos.

\begin{tabular}{ccccccccc}
\hline \hline \multicolumn{7}{c}{ ELISA-indireto } \\
\hline SLR & Diluições do "pool" de soros positivos em "pool” de soros negativos para \\
\multicolumn{10}{c}{ anticorpos IgM anti-formas eritrocitárias de $P$. falciparum } \\
& $1 / 2$ & $1 / 3$ & $1 / 4$ & $1 / 8$ & $1 / 16$ & $1 / 32$ & $1 / 64$ & $1 / 128$ \\
D.O. & 0,417 & 0,347 & 0,251 & 0,247 & 0,173 & 0147 & 0,132 & 0,124 \\
\hline \hline
\end{tabular}




\section{Anexo IV - Padronização do ELISA-IgA}

Média das densidades ópticas obtidas no ELISA com diferentes diluições dos soros controles positivos e soros negativos para anticorpos IgA antiformas eritrocitárias de $P$. falciparum e diferentes diluições dos conjugados.

\begin{tabular}{|c|c|c|c|c|c|c|c|}
\hline \multicolumn{8}{|c|}{ ELISA - resultados } \\
\hline \multirow[t]{2}{*}{ Soros } & & \multicolumn{6}{|c|}{ Diluição do conjugado anti-lgA humana } \\
\hline & diluição & $1 / 100$ & $1 / 200$ & $1 / 400$ & $1 / 800$ & $1 / 1000$ & $1 / 2000$ \\
\hline \multirow{4}{*}{ positivos } & $1 / 25$ & 2,135 & 2,049 & 1,611 & 1,028 & 0,539 & 0,381 \\
\hline & $1 / 50$ & 1,912 & 1,549 & 1,001 & 0,678 & 0,367 & 0,266 \\
\hline & $1 / 100$ & 1,418 & 1,007 & 0,678 & 0,445 & 0,212 & 0,140 \\
\hline & $1 / 200$ & 0,959 & 0,609 & 0,443 & 0,260 & 0,121 & 0,085 \\
\hline \multirow{3}{*}{ negativos } & $1 / 25$ & 1,341 & 0,947 & 0,663 & 0,457 & 0,208 & 0,134 \\
\hline & $1 / 50$ & 0,923 & 0,608 & 0,456 & 0,326 & 0,129 & 0,087 \\
\hline & $1 / 100$ & 0,677 & 0,382 & 0,298 & 0,204 & 0,077 & 0,055 \\
\hline
\end{tabular}


VIII. REFERÊACIAS BIBLIOGRÁFICAS 
Abbas, AB, Lichtman, AH, Pober, JSP. In: Cellular and Molecular Immunology, 2000; $4^{\text {a }}$ ed., WB Saunders Company.

Allen, J. Immunology of Human Helminth Infection Int. Arch. Allergy Clin. Immunol. 1993; 109: 3-10.

Aribot G, Rogier C, Sarthou JL, Trape JF, Balde, AT, Druilhe P, Roussilhon C. Pattern of Immunoglobulin Isotype Response to Plasmodium falciparum Blood-Stage Antigens in Individuals Living in a Holoendemic Area of Senegal (Dielmo, West Africa) Am. J. Trop. Med. Hyg. 1996; 54(5):449-457.

Aucan C, Traoré Y, Tall F, Nacro B, Traoré-Leroux T, Fumoux F, Rihet P. High Immunoglobulin G2 (IgG2) and Low G4 (lgG4) Levels are Associated with Human Resistance to Plasmodium falciparum Malaria Infect. Immun. 2000; 68(3): 1252-1258.

Avila SLM, Oliveira MS, Leandro, MC, Arruk, VG, Carvalho Filho NR, Boulos M, Ferreira AW. Malária Humana: Definição de Perfis Sorológicos por Western Blotting e ELISA. Rev. Inst. Med. Trop. São Paulo, 1993; 35 (S10): S 32.

Ávila SLM, Ogando SLA, Nunes Mal, Durlacher, RR, Pang L, Ferreira AW. Análise do Comportamento de Anticorpos IgA Anti - Plasmodium falciparum, por ELISA, em Pacientes Submetidos a Terapêutica Antimalárica. Rev. Soc. Bras. Med. Trop. 1999; 32(I): 277.

Baird JK. Age-dependent Characteristics of Protection v. Susceptibility to Plasmodium falciparum Ann. Trop. Med. Parasitol. 1998; 92(4):367-90.

Baird JK. Host Age as a Determinant of Naturally Acquired to Plasmodium falciparum Parasitol. Today 1995; 11(3):105-111.

Berendt AR, Simmons DL, Tansey J, Newbold Cl, Marsh K. Intercellular Adhesion Molecule-1 as an Endothelial Cell Adhesion Receptor for Plasmodium falciparum Nature 1989; 341: 57-59. 
Boudin C, Chumpitazi B, Dziegel M, Peyron F, Picot S, Hogh B, AmbroiseThomas P. Possible Role of Specific Immunoglobulin M Antibodies to Plasmodium falciparum Antigens in Immunoprotection of Human Living in a Hyperendemic Area, Burkina Faso J. Clin. Microbiol. 1993; 31(3): 636-641.

Bouharoun-Tayoun H \& Druilhe P. Plasmodium falciparum Malaria: Evidence for an Isotype Imbalance which May Be Responsible for Delayed Acquisition of Protective Immunity Infect. Immun. 1992; 60(4): 1473-1481.

Bouharoun-Tayoun H, Oeuvray C, Lunel F, Druilhe P. Mechanisms Underlying the Monocyte-mediated Antibody-dependent Killing of Plasmodium falciparum Asexual Blood Stages J. Exp. Med. 1995; 182: 409418.

Bouharoun-Tayoun $\mathrm{H}$, Attanath $\mathrm{P}$, Sabchareon A, Chongsuphajaisiddhi $\mathrm{T}$, Druilhe P. Antibodies that Protect Humans against Plasmodium falciparum Blood Stages Do Not on their Own Inhibit Parasite Growth and Invasion in vitro, but Act in Cooperation with Monocytes J. Exp. Med. 1990; 172:16331641.

Brown GV, Anders RS, Knowles G. Differential Effect of Immunoglobulin on the in vitro Growth of Several Isolates of Plasmodium falciparum. Infect. Immun., 1983; 39: 1228-1235.

Brown. IN. Immunological Aspects of Malaria Infection Adv. Immunol. 1969; 2: $267-349$.

Bruce-Chwatt LJ. In: Essential Malariology, 1985; $2^{\mathrm{a}}$ ed., William Heisemann Medical Books, London.

Calich V, Vaz C. In: Imunologia 2001; p. 72, Revinter.

Calissano C, Modiano D, Sirina BS, Konate A, Sanou I, Sawadogo A, Perlmann H, Troye-Blomberg M, Perlmann P. IgE Antibodies to Plasmodium 
falciparum and Severity of Malaria in Children of one Ethnic Group Living in Burkina Faso Am. J. Trop. Med. Hyg. 2003, 69(1):31-35.

Camargo ME, Silva, SM, Leser PG, Granato CH. Avidez de Anticorpos IgG Específicos como Marcadores de Infecção Primária Recente pelo Toxoplasmose gondii Rev. Inst. Med. Trop. São Paulo 1991; 33: 213-218.

Capron M, Capron A: Immunoglobulin $E$ and Effector Cells in Schistosomiasis Science, 1994; 24: 1876-1877.

Carter R, Chen DH. Malaria Transmission Blocked by Immunization with Gametes of the Malaria Parasite Nature 1976; 203: 57.

Carter R, Mendis KN. Evolutionary and Historical Aspects of the Burden of Malaria Clin. Microbiol. Rev. 2002; 15(4): 564-594.

Carter R, Graves PM, Quakyi IA, Good MF. Restricted or Absent Immune Responses in Human Populations to Gamete Antigens that are Targets of Malaria Transmission-blocking Antibodies J. Exp. Med. 1989; 169: 135-147.

Celada A, Cruchaud A, Perrin LH. Phagocytosis of Plasmodium falciparum Parasitized Erythrocytes by Human Polymorphonuclear Leukocytes. J. Parasito. 1983; 69: 49-53.

Chen Q, Schichtherle M, Wahlgren M. Molecular Aspects of Severe Malaria Clin. Microbiol. Rev. 2000; 13: 439-450.

Chumpitazi BFF, Lepers J-P, Simon J, Deloron P. IgG1 and IgG2 Antibody Responses to Plasmodium falciparum Exoantigens Correlate inversely and Positively, Respectively, to the Number of Malaria Attacks FEMS Immunol. Med. Microbiol.1996; 14:151-158.

Clark IA, Rockett KA, Cowden WB. Proposed Link between Cytokines, Nitric Oxide and Human Cerebral Malaria Parasitol. Today 1991; 7: 205-207. 
Cooke GS, Aucan C, Walley AJ, Segal S, Greenwood BM, Kwiatkowski DP, Hill AVS. Association of Fcy Receptor IIA (CD32) Polymorphism with Severe Malaria in West Africa Am. J. Trop. Med. Hyg. 2003; 69(6): 565-568.

Cox FEG. History of human Parasitology Clin. Microbiol. Rev. 2002; 15(4):595-612.

Day KP, Marsh K. Naturally Acquired Immunity to Plasmodium falciparum Parasitol. Today 1991; 7: A68-A70.

Deane LM. Malaria Studies and Control in Brazil Am. J. Trop Med. Hyg. 1988; 38(2): 223-230.

Deloron P, Dubois B, Le Hesran JY, Riche D, Fievet N, Cornet M, Ringwald P, Cot M. Isotypic Analysis of Maternally Transmitted Plasmodium falciparum-specific Antibodies in Cameroon and Relationship with Risk of Plasmodium falciparum Infection Clin. Exp. Immunol. 1997; 110: 212-218.

Desowitz RS. Plasmodium falciparum Immunoglobulin E in Sera from an area of Holoendemic Malaria Trans. R. Soc. Trop. Med. Hyg, 1989: 83:479479.

Desowitz RS, Elm J, Alpers MP. Plasmodium falciparum - Specific Immunoglobulin $\mathrm{G}(\lg \mathrm{G})$, IgM and $\lg \mathrm{E}$ Antibodies in Paired Maternal-Cord Sera from East Sepik Province, Papua New Guinea Infect. Immun. 1993; 61(3):988-993.

Diallo TO, Spiegel A, Diouf A, Lochouarn L, Kaslow DC, Tall A, Perraut R, Garraud O. Short Report: Differential Evolution of Immunoglobulin G1/G3 Antibody Responses to Plasmodium falciparum $\mathrm{MSP}_{19}$ over Time in Malariaimmune Adult Senegalese Patients Am. J. Trop. Med. Hyg. 2002; 66(2): $137-$ 139. 
Diamandis EP, Christopoulos TK. The Biotin-(Strept) Avidin System: Principles and Applications in Biotechnology Clin. Chem. 1991; 37(5):625636.

Ding AH, Nathan CF, Stuehr DJ. Release of Reactive Nitrogen Intermediates and Reactive Oxygen Intermediates from Mouse Peritoneal Macrophages: Comparison of Activating Cytokines and Evidence for Independent Production J. Immunol. 1988. 141: 2407-2412.

Dobson MJ. The Malariology Centenary Parassitologia 1999; 41:21-32.

Dubois B, Deleron P, Astagneau P, Chougnet C, Lepers JP. Isotypic Analysis of Plasmodium falciparum- specific Antibodies and their Relation to Protection in Madagascar Infect. Immun. 1993; 61(10): 4498-4500.

Dugas B, Mossalayi D, Damais C, Kolb JP. Nitric Oxide Production by Human Monocytes: Evidence for a Role of CD23 Immunol. Today 1995; 16 : 574- 580 .

Durlacher RR. Avaliação da Resposta Imune Humoral em Pacientes com Infecção por Plasmodium falciparum Submetidos à Terapêutica Específica em Região de Transmissão Instável de Malária no Brasil. São Paulo, 1998. Dissertação (Mestrado) - Faculdade de Medicina, Universidade de São Paulo.

Edozien JC, Gilles HM, Udeozo IOK. Adult and Cord Blood Gammaglobulin and Immunity to Malaria in Nigerians Lancet ii 1962; 951-955.

Elghazali G, Perlmann H, Rutta AS, Perlmann P, Troye-Blomberg M. Elevated Plasma Levels of IgE in Plasmodium falciparum-primed Individuals Reflect an Increased Ratio of IL-4 to Interferon-gamma (IFN-gamma)producing Cells. Clin. Exp. Immunol. 1997; 109:84-89. 
Ferreira AW. Imunodiagnostico de la Malaria. In: Antunãno FJ \& Schmuñis G Diagnostico de la Malaria. Organizacion Panamericana de la Salud 1988 (Publicação Científica n 512): 65-75.

Ferreira MU, Liu Q, Zhou M, Kimura M, Kaneko O, Thien HV, Isomura S, Tanabe K., Kawamoto, F. Stable Patterns of Allelic Diversity at the Merozoite Surface Protein-1 Locus of Plasmodium falciparum in Clinical Isolates from Southern Vietnam J. Eukaryot. Microbiol. 1998; 45: 131-136.

Ferreira MU, Kimura EAS, Souza JM, Katzin AM. The Isotype Composition and Avidity of Naturally Acquired anti-Plasmodium falciparum Antibodies: Differential Patterns in Clinically Immune Africans and Amazonians Patients Am. J. Trop. Med. Hyg. 1996; 55(3):315-323.

Fossati G, Bucknall RC, Edwards SW. Fcy Receptors in Autoimmune Diseases Eur. J. Clin. Invest. 2001; 31: 821-831.

Fujioka H, Aikawa M. Structure and Life Cycle Chem. Immunol. 2002; 80:126.

Fundação Nacional de Saúde Boletim Eletrônico Epidemiológico On Line 2003; http://www.funasa.gov.br.

Fundação Nacional de Saúde Investe mais de R 140 milhões no Combate à Malária Guia de Vigilância Epidemiológica 1999; Dezembro.

Garraud O, Nutman TB. The Role of Cytokines in Human B-cell Differentiation into Immunoglobulin-secreting Cells Bull. Inst. Pasteur, 1996; 94: 285-309.

Garraud O, Mahanty S, Perraut R. Malaria-specific Antibody Subclasses in Immune Individuals: a Key Source of Information for Vaccine Design Trends Immunol. 2003; 24(1):30-35. 
Ghigo D, Todde R, Ginsburg H, Costamagna C, Gautret P, Bussolino F, Ulliers D, Giribaldi G, Deharo E, Gabrielli G, Pescarmona G, Bosia A. Erythrocyte Stages of Plasmodium falciparum Exhibit a High Nitric Oxide Synthase (NOS) Activity and Release an NOS-inducing Soluble Factor $\mathrm{J}$. Exp. Med. 1995; 182: 677-688.

Good MF, Doolan D. Immune effector mechanisms in malaria Curr. Opin. Immunol, 1999; 11:412-419.

Gravely SM, Kreirer, JP. Adoptive transfer of Immunity to Plasmodium bergei with Immune T and B Lymphocytes Infect. Immun. 1976; 14: 184-190.

Greenberg AE, Ntumbanzondo M, Ntula N, Mawa L, Howell J, Davachi F. Hospital Surveillance of Malaria-related Paediatric Morbidity and Mortality in Kinhasa, Zaire Bull. WHO, 1989; 67: 189-196.

Greenberg S, Slverstein SC. Phagocytosis. In: Fundamental Immunology, Paul WE (ed) New York, 1993; Raven Press p.941-964.

Greenwood BM. Asymptomatic Malaria Infections - Do They Matter? Parasitol. Today 1987; 3(7): 206-214.

Greenwood B. What Can the Residents of Malaria Endemic Countries Do To Protect Themselves Against Malaria? Parassitologia, 1999; 41: 295-299.

Groux H, Gysin J. Opsonization as an Effector Mechanism in Human Protection against Asexual Blood Stages of Plasmodium falciparum: Functional Role of IgG Subclasses Res. Immunol. 1990; 141: 529-542.

Harte PG, Cooke A, Playfair JH. Specific Monoclonal IgM is a Potent Adjuvant in Murine Malaria Vaccination Nature 1983; 302: 256-258.

Heddini A. Malaria Pathogenesis a Jigsaw with an Increasing Number of Pieces Int. J. Parasitology 2002; 32: 1587-1598. 
Helmby H, Troye-Blomberg M. Differential Immunoglobulin E and Cytokine Responses in BALB/C and C57BI/6 Mice During Repeated Infections with Blood-stage Plasmodium chabaudi Malaria Parasite Immunol. 2002; 22:185190.

Helmby H, Perlmann H, Troye-Blomberg M, Perlmann P. Immunoglobulin E Elevation in Plasmodium chabaudi Malaria Infect. Immun. 1996; 64(4):14321433.

Hirunpetcharat C, Tian JH, Kaslow DC, Van Rooijen N, Kumar S, Berzofsky J, A, Miller LH, Good MF. Complete Protective Immunity Induce in Mice by immunization with the 19-kilodalton Carboxyl-terminal Fragment of Merozoite Surface Protein-1 $\left(\mathrm{MSP}_{19}\right)$ of Plasmodium yoelii Expressed in Saccharomyces cerevisiae: Correlation of Protection with Antigen-specific Antibody Titer, but not with Effector CD4 ${ }^{+}$Cells J. Immunol. 1997; 159: 34003411.

Hoffman SL, Franke ED. Inducing Protective Immune Responses against the Sporozoite and Liver Stages of Plasmodium falciparum. Immunol. Letters 1994; 41: 89-94.

Jakobsen PH, Bate CAW, Taverne J, Playfair JHL. Malaria: Toxins, Cytokines and Disease Parasite Immunol. 1995; 17: 223-231.

Jarrett, EEE, Miller HRP. Production and Activities of IgE in Helminth Infection Progress Allergy 1982; 31:178-233.

Jayawardena AN, Janeway CA, Kemp JD. Experimental Malaria in the CBA N Mouse J. Immunol. 1979; 123: 2532-2539.

Jelinek T, Schulte C, Behrens R, Grobusch MP, Coulaud JP, Bisoffi Z, Matteelli A, Clerinx J, Corachán M, Puente S, Gjopup I, Harms G, Kollaritsch $\mathrm{H}$, Kotlowski A, Björkmann A, Delmont JP, Knobloch J, Nielsen LN, Cuadros J, Hatz C, Beran J, Schmid ML, Schulze M, Lopez-Velez R, Fleischer K, Kapaum A, Mcwhinney P, Kern P, Atougia J, Fry G, Cunha S, Boecken G. 
Imported Falciparum Malaria in Europe: Sentinel Surveillance Data from the European Network on Surveillance of Imported Infectious Diseases Clin. Infect. Dis. 2002; 34:572-576.

Jensen JB, Boland MT, Akood M. Induction of Crisis Forms in Cultured Plasmodium falciparum with Human Immune Serum from Sudan. Science, 1982; 216: 2130-2133.

Jiang, XM, Arepally G, Poncz M, Mckenzie S. Rapid detection of the Fcy RIIA-H/R $R^{131}$ ligand- binding Polymorphism using an Allele- specific Restriction Enzyme Digestion (ASRED) J. Immunol. Methods 1996; 199:55-59.

Khalife JD, Dunne DW, Richardson, BA, Mazza G, Thorne KJ, Capron A, Butterworth AE. Functional Role of Human IgG Subclasses in Eosinophilmediated Killing of Schistosomula of Schistosoma mansoni J. Immunol. 1989; 142: 4422-4427.

Khusmith S, Druilhe P. Cooperation between Antibodies and Monocytes that Inhibit in vitro Proliferation of Plasmodium falciparum. Infect. Immun. 1983; 41: 219-221.

Knell AJ (ed.) Malaria 19910xford university press, Oxford.

Kwiatkowski D. Malarial Toxins and Regulation of Parasite Density Parasitol. Today 1995; 11: 115-123.

Kwiatkowski D, Hill AVS, Sambou I, Twumasi P, Castracanee J, Manogue KR, Ceramo, Brewster DR, Greenwood BM. TNF Concentrations in Fatal Cerebral, Non-cerebral and Uncomplicated Plasmodium falciparum Malaria Lancet, 1990; 336:1201-1024.

Lacerda MVG, Santos PJT, Alecrim, WD, Alecrim MGC. Malária Grave e Terapia Intensiva na Fundação de Medicina Tropical-AM: Experiência de Dois Anos Rev. Soc. Bras. Med. Trop. 34(I): 73-74, 2001. 
Luty AJF, Mayombo J, Lekoulou F, Mshana R. Immunologic Responses to Soluble Exoantigens of Plasmodium falciparum in Gabonese Children Exposed to Continuous Intense Infection Am. J. Trop. Med. Hyg. 1994; 51(6): 720-729.

Luty AJ, Perkins DJ, Lell B, Schmidt-Ott R, Lehman LG, Luckner D, Greve B Matousek, P, Herbich, K, Schmid, D. Weinberg, JB; Kremsner, PG. Low Interleukin-12 Activity in Severe Plasmodium falciparum Malaria Infect. Immun. 2000; 68(7): 3909-3015.

MacDonald G. In: The Epidemiology and Control of Malaria 1957; OxFord University Press London, United Kingdom.

Maeno Y, Perlmann P, Perlmann H, Kusuhara Y, Taniguchi K, Nakabayashi T, Win K, Looarreesuwan S, Aikawa M. IgE Deposition in Brain Microvessels and on Parasited Erythrocytes from Cerebral Malaria Patients Am. J. Trop. Med. Hyg. 2000; 63 (3-4): 128-132.

Maeno Y, Steketee R, Nagatake T, Tegoshi T, Desowitz RS, Wirima JJ, Aikawa M. Immunoglobulin Complex Deposits in Plasmodium falciparum infected Placentas from Malawi and Papua New Guinea Am. J. Trop. Med. Hyg. 1993; 49(5): 574-580.

Majarian WR, Daly TM, Weidanz WP, Long CA. Passive immunization Against Murine Malaria with an IgG3 Monoclonal Antibody J. Immunol. 1984; 132:3131-3137.

Malaguarnera L \& Musumeci S. The Immune Response to Plasmodium falciparum malaria Lancet Infect. Dis. 2002; 2: 472-478.

Manis, JP, Tian T, Alt FW. Mechanisms and Control of Class- switch Recombination Trends Immunol. 23(1):31-39, 2002.

Matsumoto S, Yukitake H, Kambara H, Yamada H, Kitamura A, Yamada T. Mycobacterium bovis bacillus Calmette-guerin Induces Protective Immunity 
Against Infection by Plasmodium yoelii at Blood-stage Depending on Shifting Immunity Toward Th1 Type and Inducing Protective IgG2a After the Parasite Infection Vaccine 2000; 19:779-787.

Mcgregor IA. The Passive Transfer of human Malarial Immunity Am. J. Trop. Med. Hyg. 1964; 13:237-239.

Mcguire W, Hill AVS, Allsopp CEM, Greenwood BM, Kwiatkowski D. Variation in the TNF- $\alpha$ Promoter Region Associated with Susceptibility to Cerebral Malaria Nature 1994; 371: 508-511.

Miller $\mathrm{H}$. Mucosal Mast Cells and the Allergic Response against Nematode Parasites Vet. Immunol. Immunopathol. 1996; 54:331-336.

Miller LH, Baruch DI, Marsh K, Doumbo OK. The Pathogenic Basis of Malaria Insight Review articles Nature 2002; 415(7):673-679.

Miller LH, Good, MF, Milon G. Malaria Pathogenesis Science 1994; 264(5167): 1878-83.

Mitchell GH, Butcher A, Voller A, Cohen S. The Effect of Human Immune IgG on the in vitro Development of Plasmodium falciparum Parasitology, 1976; 72: $149-162$.

Mungai M, Tegtmeier G, Chamberland M; Parise M. Transfusion-transmitted Malaria in the United States from 1963 Trough 1999 N. Engl. J. Med. 2001; 344(26): 1973-1978.

Naotunne TS, Karunaweera ND, Del Giudice G, Kularatne MU, Grau GE, Carter R, Mendis KN. Cytokines Kill Malaria Parasites During Infection Crisis: Extracellular Complementary Factors Are Essential J. Exp. Med. 1991; 173(3):523-529. 
Nardin EH, Nussenzweig RS, Mcgregor IA; Bryan JH. Antibodies to Sporozoites: Their Frequent Occurrence in Individuals Living in an Area of Hyperendemic Malaria. Science, 1979; 206:597-9.

Newbold C, Craig A, Kyes S, Rowe A, Fernandez-Reyes D, Fagan T. Cytoadherence, Pathogenesis and the infected Red Cell Surface in Plasmodium falciparum Int. J. Parasitol. 1999; 29: 927-937.

Ntoumi F, Contamin H, Rogier C, Bonnefoy S, Trape J-F, Mercereau-Puijalon O. Age- dependent Carriage of Multiple Plasmodium falciparum Merozoite Surface Antigen-2 Alleles in Asymptomatic Malaria Infections Am. J. Trop. Med. Hyg. 1995; 52(1): 81-88.

Pasvol G, Weatherall DJ, Wilson RJM. Effects of Foetal Haemoglobulin on Susceptibility of Red Cells to Plasmodium falciparum Nature 1977; 270: 171173.

Perlmann H, Helmby H, Hagstedt M, Carlson J, Larsson PH, Troye-Blomberg M, Perlmann P. IgE Elevation and IgE anti-malarial Antibodies in Plasmodium falciparum Malaria: Association of High IgE Levels with Cerebral Malaria Clin. Exp. Immunol. 1994; 97:284-292.

Pleass, RJ, Woof J. Fc Receptors and Immunity to Parasites Trends Parasitol. 17(11):S45-S51, 2001.

Potocnjak P, Yoshida N, Nussenzweig R, Nussenzweig V. Monovalent Fragments (Fab) of Monoclonal Antibodies to a Sporozoite Surface Antigen (Pb44) Protect Mice against malarial Infection J. Exp .Med. 1980; 151: 15041513.

Rank RG, Weidanz WP. Non-sterilizing Immunity in Avian Malaria: an Antibody-independent Phenomenon Proc. Soc. Exp. Biol. Med. 1976; 151: 257-259.

Ravetch JV, Kinet J. Fc receptors Ann. Rev. Imunol. 1991; 9: 457-492. 
Read, D, Lensen, AH, Berganie S, Haley S, Raza A, Carter R. Transmission-blocking Antibodies against Multiple, Non-variant Target Epitopes of the Plasmodium falciparum Gamete Surface Antigen Pfs230 are All Complement-fixing Parasite Immunol. 1994; 16(10): 511-519.

Richards AL. Tumour Necrosis Factor and Associated Cytokines in the Host's Response to Malaria Int. J. Parasitol. 1997; 27(10): 1251-1263.

Rihet P, Demeure CE, Ouattara M, Bourgois A, Carvalho D, Dessein AJ. Immunological Mechanisms of Human Resistance to Schistosome Infection; the Protective Effect of Immunoglobulin E is Balanced by a Blocking Action of Immunoglobulin G4 In Proceedings of the $15^{\text {th }}$ European Congress of Allergology and Clinical Immunology, 1992, Paris. Advances in Allergology and Clinical Immunology, EAACI, Stockholm, Sweden.

Roberts DW, Weidanz WP. T-cell Immunity to Malaria in the B-cell Deficient Mouse Am. J. Trop. Med. Hyg. 1978; 28: 1-3.

Rzepczyk CM, Hale K, Woodroffe N, Bobogare A, Csurhers P, Ishii A, Ferrante A. Humoral Immune Responses of Solomon Islanders to the Merozoite Surface Antigen 2 of Plasmodium falciparum Show Pronounced Skewing Towards Antibodies of the Immunoglobulin G3 Subclass Infect. Immun 1997; 65(3): 1098-1100.

Sáez-Alquezar A, Val Ramos AMS, Di Santi SM, Branquinho S, Kirchgatter K, Corddeiro IAC, Murta M, Saraiva CPJ, Oliveira SG, Bochetti, MGG, Pirolla J A, Guerzoni D, Chamone DAF. Controle da Malária Transfusional em Região Endêmica e Não Endêmica do Brasil Rev. Soc. Bras. Med. Trop. 1998; 31(1): 27-34.

Sarthou J-L, Angel G, Aribot G, Rogier C, Dieye A, Balde AT, Diatta B, Seignot P; Roussilhon C. Prognostic Value of Anti - Plasmodium falciparum Specific Immunoglobulin G3, Cytokines and their Soluble Receptors in West African Patients with Sever Malaria Infect. Immun. 1997; 65(8):3271-3276. 
Shahabudin M, Toyoshima T, Aikawa M, Kaslow DC. Transmission-blocking ctivity of a Chitinase Inhibitor and Activation of Malarial Parasite Chitinase by Mosquito Protease Proc. Natl. Acad. Sci. USA 1993; 90: 4266-4270.

Shi YP, Sayed U, Qari SH, Roberts, JM, Udhayakumar V, Oloo AJ, Hawley W A; Kaslow DC, Nahlen BL, Lal AA. Natural Immune Response to the Cterminal 19-kilodalton Domain of Plasmodium falciparum Merozoite Surface Protein 1 Infect. Immun. 1996; 64: 2716-2723.

Sinnis P, Nussenzweig V. Preventing Sporozoite Invasion of Hepatocytes In: Malaria Vaccine Development, 1996 Hoffmann SL (ed.) American Society for Microbiology Press, Washington, D. C, p.15-33.

Smith E, Taylor-Robinson AW. Parasite-specific Immunoglobulin Isotypes during Lethal and Non-lethal Murine Malaria Infections Parasitol. Res. 2003; 89:26-33.

Smith NC, Favila-Castillo L, Monroy-Ostria A, Hirunpetcharat C, Good MF. The Spleen, IgG Antibody Subsets and Immunity to Plasmodium berghei in Rats Immunol. Cell Biol. 1997; 75: 318-323.

Snounou G, Viriyakosol S, Jarra W, Thaithong S, Brown KN. Identification of the Four Human Malaria Parasite Species in Field Samples by the Polymerase Chain Reaction and Detection of a High Prevalence of Mixed Infections. Mol. Biochem. Parasitol. 1993; 58: 283-92.

Snow RW, Bastos De Azevedo I, Lowe BS, Kabiru EW, Nevill CG, Mwankusye S, Kassiga G, Marsh K, Teuscher T. Severe Childhood Malaria in Two Areas of Markedly Different Falciparum Transmission in East Africa Acta Trop. 1994; 57: 289-300.

Soe-Soe, Theisen M, Roussilhon C, Khin-Saw-Aye, Druilhe P. Association Between Protection Against Clinical and Antibodies to Merozoite Surface Antigen in an Area of Hyperendemicity in Myanmar: Complementary 
Between Responses to Merozoite Surface Protein 3 and the 220-kilodalton Glutamate-rich Protein Infect. Immun 2004;72(1): 247-252.

Stewart MJ, Nawrot RJ, Schulman S, Vanderberg. Plasmodium berghei Sporozoite invasion is Blocked in vitro by Sporozoite-immobilizing Antibodies Infect. Immun. 1986; 51:859-864.

Su Z, Stevenson MM. Central Role of Endogenous Gamma Interferon in Protective Immunity against Blood-stage Plasmodium chabaudi AS Infection. Infect. Immun 2000; 68: 4399-4406.

Tangteerawatana P, Krudsood S, Chalermrut K, Looareesuwan S, Khusmith S. Natural Human IgG Subclass Antibodies to Plasmodium falciparum Blood Stage Antigens and their Relation to Malaria Resistance in an Endemic Area of Thailand Southeast Asian J. Trop. Med. Public Health 2001; 32(2):247254.

Taylor RR, Allen SJ, Grenwood, BM, Riley EM. IgG3 Antibodies to Plasmodium falciparum Merozoite Surface Protein 2 (MSP2): Increasing Prevalence with age and Association with Clinical Immunity to Malaria Am. J. Trop. Med. Hyg. 1998; 58(4):406-413.

Taylor-Robinson AW. A Model of Development of Acquired Immunity to Malaria in Humans Living Under Endemic Conditions Med. Hypotheses 2002; 58: 148-156.

Taylor-Robinson AW. Malaria-specific $\lg E$ as Risk factor for cancer and Atopy Am. J. Trop. Med. Hyg. 1998; 59(2): 181.

Taylor-Robinson AW, Philips RS, Severo A, Moncada S, Liew FY. The role of Th1 and Th2 Cells in a Rodent Malaria Infection. Science 1993; 260:19131914.

Trager W, Jensen JB. Human Malaria Parasites in Continuous Culture Science 1976; 193:673-675. 
Troye-Blomberg M, Perlmann P, Nilsson M, Perlmann H. Immune Regulation of Protection and Pathogenesis in Plasmodium falciparum Malaria Parassitologia 1999; 41:131-138.

Troye-Blomberg M, Riley EM, Kaliban M, Holmberg M, Perlmann $H$, Andersson $\mathrm{U}$, Heusser $\mathrm{CH}$, Perlmann P. Production by Activated Human $\mathrm{T}$ Cells of Interleukin 4 but not Interferon- $\gamma$ is Associated with Elevated Levels of Serum Antibodies to Activating Malaria Antigens Proc. Natl. Acad. Sci. USA 1990; 87: 5484-5488.

Van Sorge NM, Van der Pol W-L, Van de Winkel JGJ. FcyR Polymorphisms: Implications for Function, Disease Susceptibility and Immunotherapy Tissue Antigens 2003; 61: 189-202.

Vukovic P, Hogarth PM, Barnes N, Kaslow DC, Good MF. Immunoglobulin G3 Antibodies Specific for the 19-kilodalton Carboxyl-terminal Fragment of Plasmodium yoelii Merozoite Surface Protein 1 Transfer Protection to Mice Deficient in c-gammaR1 Receptors Infect. Immun. 2000; 68:3019-3022.

Warmerdam PA, Winkel V, Vlug JG, Westerdaal NA, Capel PJ. A Single Amino in the second Ig-like Domain of the Human Fc $\gamma$ receptor II is Critical for Human IgG2 Binding J. Immunol. 1991; 147:1338-43.

Weatheral DJL, Miller LH, Baruch DI, Marsh K, Doumbo OK, Casals-Pascual C, Roberts D J. Malaria and the Red Cell Hematology 2002; 35-57.

White KL, Snyder HL, Krzych U. MHC Class I-dependent Presentation of Exoerythrocytic Antigens to $\mathrm{CD}^{+} \mathrm{T}$ Lymphocytes is Required for Protective Immunity against Plasmodium berghei J. Immunol. 1996; 156:3374-338.

Wilson MB, Nakane PK. Recent Developments in the Periodate Method of Conjugating Horseradish Peroxidase (HRPO) to Antibodies. In: Immunofluorescence and Related Staining Techniques Knapp W, Holubar K, Wick G, 1978, Amsterdam, Elsevier, p.215-224. 
Winkler S, Willheim M, Baier K, Schmid D, Aichelburg, A, Graninger, W, Kremsner PG. Reciprocal Regulation of Th1- and Th2-Cytokine-Producing T Cells during Clearance of Parasitemia in Plasmodium falciparum Malaria Infect. Immun. 1998; 66(12):6040-6044.

World Health Organization: Malaria. WHO Fact Sheet, 2003; nº 94.

World Health Organization: Ministerial Conference on Malaria Weekly Epidemiol. Rec. 1992; 67:349-350.

World Health Organization Roll Back Malaria: Resolution of the Executive Board on the WHO 1999; 52 ${ }^{\mathrm{a}}$ World Health Assembly.

Woznicova V. Immunoglobulin G Avidity in Infectious Diseases Epidemiol. Mikrobiol. Imunol. 2004 ;53(1):4-11.

www.ahcpub.com 